\title{
Arbeidsmarktmonitor metalektro : editie 2011
}

\author{
Citation for published version (APA):
}

van Breugel, G. A. A., Fouarge, D., de Grip, A., Kriechel, B., \& van Thor, J. A. F. (2011).

Arbeidsmarktmonitor metalektro : editie 2011. Researchcentrum voor Onderwijs en Arbeidsmarkt, Faculteit der Economische Wetenschappen. ROA Reports No. 4

https://doi.org/10.26481/umarep.2011004

Document status and date:

Published: 01/01/2011

DOI:

10.26481/umarep.2011004

Document Version:

Publisher's PDF, also known as Version of record

\section{Please check the document version of this publication:}

- A submitted manuscript is the version of the article upon submission and before peer-review. There can be important differences between the submitted version and the official published version of record.

People interested in the research are advised to contact the author for the final version of the publication, or visit the DOI to the publisher's website.

- The final author version and the galley proof are versions of the publication after peer review.

- The final published version features the final layout of the paper including the volume, issue and page numbers.

Link to publication

\footnotetext{
General rights rights.

- You may freely distribute the URL identifying the publication in the public portal. please follow below link for the End User Agreement:

www.umlib.nl/taverne-license

Take down policy

If you believe that this document breaches copyright please contact us at:

repository@maastrichtuniversity.nl

providing details and we will investigate your claim.
}

Copyright and moral rights for the publications made accessible in the public portal are retained by the authors and/or other copyright owners and it is a condition of accessing publications that users recognise and abide by the legal requirements associated with these

- Users may download and print one copy of any publication from the public portal for the purpose of private study or research.

- You may not further distribute the material or use it for any profit-making activity or commercial gain

If the publication is distributed under the terms of Article $25 \mathrm{fa}$ of the Dutch Copyright Act, indicated by the "Taverne" license above, 


\section{Arbeidsmarktmonitor Metalektro}

\section{Editie 2011}

Gerla van Breugel

Didier Fouarge

Andries de Grip

Ben Kriechel

Jesper van Thor

ROA-R-2011/4 


\section{Colofon}

(C) Researchcentrum voor Onderwijs en Arbeidsmarkt (ROA). Niets uit deze uitgave mag op enige manier worden verveelvoudigd zonder voorafgaande schriftelijke toestemming van de directeur van het ROA.

\section{Researchcentrum voor Onderwijs en Arbeidsmarkt}

School of Business and Economics

Maastricht University

\section{Vormgeving}

ROA secretariaat, Maastricht

\section{Verkoop}

Researchcentrum voor Onderwijs en Arbeidsmarkt email: secretary-roa-sbe@maastrichtuniversity.nl website: www.roa.nl

ISBN: 978-90-532I-495-4

juni $201 \mathrm{I}$ 


\section{Inhoud}

Voorwoord $\quad$ v

Management Summary vii

I Dynamiek in de Metalektro I

I.I Ontwikkelingen in de Metalektro: conjunctuur I

I.2 De ontwikkeling van de arbeidsmarkt in $2010 \quad 2$

I.3 Structurele werkgelegenheidsontwikkeling 5

I.4 Innovatie 6

2 Arbeidsmarktontwikkelingen in 2010 9

2.I De personeelsinstroom in 2010

2.2 De personeelsuitstroom in 2010 I2

2.3 Werkgelegenheidsontwikkelingen in 20IO I3

2.4 Opbouw personeelsbestand in de Metalektro I5

3 Vacatures en werving van personeel

3.I Vacatures I9

3.2 Effectieve wervingskanalen 25

3.3 Wervingsproblemen en bijbehorende maatregelen 27

4 Competentiemanagement 35

4.I Vaststellen huidig en gewenst competentieniveau 35

4.2 Competentieniveau van de schoolverlaters 38

4.3 Ontwikkeling competenties door scholing 42

4.4 Ontwikkeling competenties door interne mobiliteit 48

4.5 HRM-instrumenten: een totaaloverzicht 50

5 Sociale innovatie 53

5.I Organisatie en management 53

5.2 Benutting en ontwikkeling van menselijk kapitaal 58

5.3 Externe samenwerking 60 
$6 \quad$ Vergrijzing 63

6.I Uitstroom vanwege pensionering $\quad 63$

6.2 Vervangingsproblemen 65

6.3 Aanpak vervangingsproblemen 68

6.4 Levensfasebewust personeelsbeleid 7I

7 De Metalektro in de toekomst 75

7.I Arbeidsmarktontwikkeling in de Metalektro op de korte termijn: 20II-20I2 75

7.2 Ontwikkelingen op de middellange termijn: 20IO-20I4 $\quad 76$

7.3 Verandering in de technische functies op de middellange termijn: 2OII-2OI5 79

7.4 HR-beleid op de middellange termijn: 20II-20I5 8I

$\begin{array}{lll}8 & \text { Agenda voor de toekomst } & 87\end{array}$

8.I Ontwikkelingen en trends 87

8.2 Agenda voor de Toekomst $\quad 92$ 


\section{Voorwoord}

Met genoegen bieden de auteurs van het Researchcentrum voor Onderwijs en Arbeidsmarkt (ROA) en opdrachtgever Stichting $\mathrm{A}+\mathrm{O}$ u de negende Arbeidsmarktmonitor Metalektro aan. De monitor bevat analyses van de actuele en toekomstige ontwikkelingen op personeels- en arbeidsmarktgebied in de Nederlandse Metalektro. De uitkomsten van deze analyses kunnen als input dienen bij het ontwikkelen van personeels- en arbeidsmarktbeleid door de individuele metalektrobedrijven, de sociale partners en andere partijen.

De rapportage die voor u ligt, vormt het sluitstuk van een onderzoekscyclus waarbij gedurende een heel jaar op verschillende momenten data is verzameld. De hoofdmoot van de bevindingen in de Arbeidsmarktmonitor Metalektro is gebaseerd op de uitgebreide internetvragenlijst die in juli 2010 en januari 2oII door het Werkgeverspanel is ingevuld. In elke meting zijn vragen beantwoord met betrekking tot in- en uitstroom en vacatures. Daarnaast is een aantal thema's verspreid over één van beide vragenlijsten: werving en selectie, inzetbaarheid en doorstroom van personeel, sociale en technologische innovatie en scholing en competenties van het technisch personeel. Het Werkgeverspanel heeft aangevuld met andere metalektrobedrijven, vier maal de Quickscan ingevuld, waarin zij aangaven hoe de werkgelegenheid en de vacatures zich in de voorgaande en de komende twee maanden ontwikkelden. Om dieper in te kunnen gaan op de achtergronden van de bevindingen uit de vragenlijsten en de Quickscans zijn een aantal metalektrobedrijven geïnterviewd en $\mathrm{A}+\mathrm{O}-\mathrm{kenniskringen}$ bezocht. De interviews en bezoeken zijn verwerkt in tekstkaders waarin de meningen van de bedrijven kernachtig worden weergegeven. Ook is gebruik gemaakt van gegevens afkomstig van het CBS en uit het schoolverlatersonderzoek en de arbeidsmarktprognoses van het ROA.

De auteurs willen op deze plaats de bedrijven bedanken die de halfaarlijkse vragenlijsten en/of de Quickscans hebben ingevuld. Een speciaal woord van dank is daarbij gericht aan de bedrijven die bereid waren om deel te nemen aan de verdiepende gesprekken. De regiecommissie, bestaande uit Henry de Groot (Stichting A+O), Rien Smit (FME-CWM) en Astrid Ophof (FNV Bondgenoten), wordt hartelijk bedankt voor hun constructieve feedback en de wijze waarop ze het onderzoek hebben begeleid. Het veldwerk en de statistische analyses voor deze monitor zijn verricht door Sander Dijksman (ROA). 



\section{Management Summary}

De Nederlandse economie herstelde in 20 Io langzaam maar zeker, wat voor de Metalektro meer bedrijvigheid, meer werkgelegenheid en een groeiend personeelsbestand betekende. Het aantal vacatures nam langzaam toe, maar de groei in het personeelsbestand werd vooral gedragen door de middelgrote en grote bedrijven. Halverwege zoro hebben vooral de bedrijven in de Machinebouw, Transportmiddelen en Elektrotechniek weer meer personeel hun personeel uitgebreid.

\section{Arbeidsmarkt}

In 2010 groeide het personeelsbestand voor nagenoeg alle functiecategorieën, maar het sterkst bij de uitvoerende technische functies. Ruim de helft van de bedrijven heeft in deze functies nieuw personeel aangenomen. Het percentage bedrijven met instroom van nieuw personeel nam in de loop van 2010 in alle functiecategorieën toe. In de tweede helft van 2010 verdubbelde het percentage bedrijven dat nieuw personeel aannam in de leidinggevende technische functies en de ondersteunende en leidinggevende niet-technische functies. De uitstroom van personeel was in de eerste helft van 2010 laag en nam licht toe in de loop van het jaar.

Sinds medio 2010 bouwt de Metalektro de flexibele schil weer op. In de tweede helft van 2010 worden er duidelijk meer flexibele arbeidskrachten aangenomen. Bedrijven nemen vooralsnog eerst tijdelijke werknemers aan tot er meer zekerheid bestaat over het doorzetten van de conjuncturele opleving. Pas dan zullen bedrijven weer vaker overgaan tot het aanbieden van vaste contracten.

\section{Technologische en sociale innovaties}

In 20 oro bleven de gerealiseerde technologische innovaties enigszins achter ten opzichte van de jaren ervoor. $80 \%$ van de bedrijven geeft aan één of meer technologische innovaties te hebben doorgevoerd. Daarbij hebben de bedrijven zich vooral gericht op het verbeteren van bestaande producten en het verbeteren van productieprocessen. In 201 verwachten de bedrijven qua innovaties weer het niveau van de jaren ervoor te bereiken. Dit lijkt echter geen structurele ontwikkeling te zijn. Voor de komende 
vijf jaar wordt er namelijk weer een terugval verwacht van het aantal technologische innovaties.

Ook werden er in 2010 in de Metalektro minder sociale innovaties geïntroduceerd dan in de voorgaande jaren. Veel bedrijven lijken op dit punt enigszins pas op de plaats te maken, want ook de komende jaren verwacht een kleiner aantal bedrijven sociale innovaties door te voeren. De bedrijven hebben op het terrein van sociale innovatie echter nog wel dezelfde voorkeuren als voorheen: het variabel inzetten van technici, projectmatig werken en samenwerken met een ander bedrijf.

\section{Voortschrijdende upgrading, PROFI-competenties en brede inzetbaarheid}

De technologische en de daaraan gerelateerde sociale innovaties leiden in veel bedrijven tot een upgrading van de vereiste competenties van het personeel. De groeiende vraag naar allround technici die zelfstandig kunnen werken, komt vooral voort uit de concurrentie die de bedrijven op hun afzetmarkt ondervinden. Om een hoge kwaliteit van de producten te kunnen realiseren en goed in te kunnen spelen op specifieke wensen van klanten moet het technisch personeel naast de noodzakelijke vaktechnische competenties ook over gedragsmatige competenties beschikken. Deze zijn in de vorige edities van de Arbeidsmarktmonitor Metalektro bestempeld als de PROFI-agenda met de volgende competenties:

- Probleemoplossend vermogen

- Relatie met klanten

- Omgaan met veranderingen

- Flexibiliteit

- Initiatief

Bedrijven verwachten dat hun personeel in de toekomst steeds vaker bovenstaande competenties moet bezitten met de nadruk op probleemoplossend vermogen en flexibiliteit. Bovendien is het erg belangrijk dat medewerkers goed kunnen samenwerken en waar nodig kennis willen delen, zowel binnen hun team als tussen afdelingen. Het is opmerkelijk dat een kwart van de bedrijven zowel behoefte heeft aan technisch specialisten als aan technische allrounders.

Deze behoefte van de bedrijven in de Metalektro wordt ook weerspiegeld in de aansluiting tussen onderwijs en arbeidsmarkt. Vier van de vijf recent ingestroomde schoolverlaters met een $\mathrm{MBO}$ - of HBO-diploma op zak, vindt dat hun functie redelijk tot goed aansluit bij de opleiding. MBO-schoolverlaters geven aan dat ze in hun functie vooral vakkennis en probleemoplossend vermogen nodig hebben, terwijl schrijven, spreken en het beheersen van vreemde talen minder van hen gevraagd worden. HBO'ers kunnen naar eigen zeggen prima voldoen aan de behoefte aan competenties wat betreft het leren van nieuwe dingen, samenwerken, ICT en discus- 
siëren. Maar hun vakkennis, besluitvaardigheid en vermogen om duidelijk te communiceren moeten volgens eigen zeggen nog worden verbeterd.

De behoefte aan werknemers die beschikken over de genoemde PROFI-competenties vloeit ook voort uit de behoefte aan breed inzetbaar personeel. Eén derde van de bedrijven zou graag zien dat hun personeel dat werkzaam is in de uitvoerende technische functies breder inzetbaar wordt dan nu het geval is.

\section{Opleidingsbeleid en interne mobiliteit}

De vereiste upgrading van het personeel en de toenemende vraag naar technici die onder andere beschikken over de genoemde PROFI-competenties, vergen aanzienlijke investeringen in trainingen en opleidingen. De uitgaven voor scholing en opleiding als percentage van de loonsom lagen in 2010 echter op een lager niveau dan in 2009. Daarentegen stegen de uitgaven per geschoolde werknemer. Al met al volgde in $201057 \%$ van de vaste werknemers, $24 \%$ van de tijdelijke werknemers en IO\% van de uitzendkrachten één of meer trainingen of cursussen. Hoewel de aandacht voor enkele gedragsmatige competenties binnen deze trainingen en cursussen toeneemt, zijn deze nog steeds hoofdzakelijk gericht op inhoudelijke vakkennis.

Naast het volgen van cursussen en trainingen is het informeel leren op de werkvloer ook van groot belang voor het ontwikkelen van de benodigde competenties. Daarom is het een goede zaak dat het bevorderen van coachend leiderschap in veel bedrijven gezien wordt als een speerpunt van het personeelsbeleid voor de komende jaren. Coachend leiderschap versterkt het informeel leren op het werk en is bij uitstek geschikt om de vereiste PROFI-competenties bij het personeel te ontwikkelen. Naast coachend leiderschap kan informeel leren ook goed worden bevorderd door het vergroten van de interne mobiliteit. In 2010 was deze interne mobiliteit binnen de metalektrobedrijven aanzienlijk hoger dan in crisisjaar 2009. Ruim de helft van de bedrijven gaf aan dat er personeel binnen het bedrijf van functie is veranderd. Deze mobiliteit heeft iets vaker een horizontaal dan een verticaal karakter door onvoldoende hogere functies en het kennisniveau bij het personeel. Juist deze horizontale mobiliteit is echter cruciaal voor het breder inzetbaar maken van het personeel.

\section{Vervangingsproblematiek en levensfasebewust personeelsbeleid}

Om ook in de toekomst aan de vraag naar personeel met de juiste competenties te kunnen voldoen, is het belangrijk om de oudere werknemers zo lang mogelijk goed inzetbaar te houden. De gemiddelde leeftijd van de werkenden in de Metalektro is met 4I,I jaar namelijk hoog en loopt voorlopig alleen maar op. De branche met gemiddeld de oudste werknemers is de Basismetaal (43,7 jaar). Meer dan één derde van de werknemers in deze branche is ouder dan 50 jaar. De 'jongste' branche is de 
Metaalproductensector (gemiddeld 40,5 jaar). Hier zijn slechts twee van de tien werknemers de 50 al gepasseerd. Door de toenemende vergrijzing komt voor steeds meer werknemers het pensioen in zicht. Deze pensionering brengt met zich mee dat een deel van de opgebouwde expertise en bedrijfsspecifieke kennis verloren kan gaan, wat verstrekkende gevolgen kan hebben voor bedrijven in de Metalektro.

Het aantal bedrijven dat problemen verwacht bij het vervangen van het technisch personeel dat de komende jaren met pensioen gaat, was in 2010 weer groter dan in het crisisjaar 2009. De meeste problemen worden er verwacht voor de uitvoerende technische functies. 7I\% van de bedrijven verwacht problemen bij het vervangen van personeel in deze functies, tegenover $65 \%$ van de bedrijven in 2009. De vervanging van ondersteunende krachten wordt door de metalektrobedrijven als minst problematisch gezien. Het percentage werknemers dat in de komende vijf jaar met pensioen zal gaan wordt anno 2010 overigens lager ingeschat dan in 2009 . Het varieert in 2010 van $0,8 \%$ voor niet-technische leidinggevenden tot $5,5 \%$ voor uitvoerende technische functies.

Door de vergrijzing en de dreigende krapte op de arbeidsmarkt (zie Hoofdstuk 3) wordt de duurzame inzetbaarheid van medewerkers belangrijker. Daarbij zal er veel aandacht moeten uitgaan naar de oudere medewerkers, zodat deze langer productief inzetbaar blijven en ook langer willen blijven werken. Een goed levensfasebewust personeelsbeleid kan oudere werknemers stimuleren om langer te blijven doorwerken en hun competenties op peil te houden. In de metalektrobedrijven zijn de meeste HR-instrumenten echter niet specifiek gericht op oudere werknemers. Wel biedt $25 \%$ van de bedrijven oudere medewerkers (gedeeltelijk) ander werk aan en ook worden oudere werknemers ingezet op functies waarin zij hun ervaringskennis kunnen doorgeven.

\section{Werving personeel}

Bedrijven zullen weer meer aandacht moeten gaan besteden aan de werving van nieuw personeel. Door een toenemende afzet, de bovengenoemde vervangingsproblematiek en de stagnerende instroom van schoolverlaters uit het technisch onderwijs zal de arbeidsmarkt voor technisch opgeleiden de komende jaren weer veel krapper worden. De in de tweede helft van 2010 oplopende duur dat vacatures open staan, is een eerste indicatie van het krapper worden van de arbeidsmarkt. De toenemende krapte op de arbeidsmarkt leidde in 2010 al tot meer wervingsproblemen. Daarbij waren de problemen het grootst bij het invullen van vacatures voor uitvoerende technische functies. Volgens 6 op de Io bedrijven beschikken de sollicitanten niet over de voor deze functies vereiste competenties. Door deze wervingsproblemen neemt in de praktijk de werkdruk toe, blijft er werk liggen, en worden bepaalde deadlines niet gehaald.

Evenals in voorgaande jaren vinden bedrijven in de Metalektro dat het inschakelen van uitzendbureaus het meest effectief is om aan uitvoerend en ondersteunend tech- 
nisch personeel te komen. Wanneer bedrijven leidinggevend technisch personeel of technisch opgeleide verkopers nodig hebben, schakelen ze het liefst een commercieel werving- en selectiebureau in. Het bieden van goede loopbaanperspectieven is volgens veel bedrijven ook een effectief middel om de wervingsproblemen voor technisch personeel te verminderen. Het overgrote deel van de bedrijven dat met wervingsproblemen te kampen heeft, tracht deze problemen op te vangen door het flexibel inzetten van het eigen personeel. Hoewel de economie in 2010 pas net weer uit het dal omhoog kruipt, is het opmerkelijk dat toch al weer I4\% van de bedrijven zich genoodzaakt ziet om de productie te beperken, omdat er te weinig geschikt personeel voor handen is.

\section{Speerpunten toekomstig personeelsbeleid}

Ook de komende jaren blijft het bevorderen van de inzetbaarheid van het huidige personeel het belangrijkste speerpunt voor het personeelsbeleid. Daarnaast zijn het verminderen van het verzuim, het bevorderen van coachend leiderschap en een levensfasebewust personeelsbeleid belangrijke speerpunten voor het personeelsbeleid.

\section{Agenda voor de toekomst}

Het rapport wordt afgesloten met een vernieuwde Agenda voor de toekomst. Deze agenda biedt metalektrobedrijven handreikingen om de komende jaren de effectiviteit van hun arbeidsmarkt- en personeelsontwikkelingsbeleid te vergroten. De Agenda voor de toekomst richt zich op zeven belangrijke aandachtspunten:

- Ontwikkelen van een lange-termijnstrategie met betrekking tot de personeelsbehoefte.

- Opleidings- en ontwikkelingsbeleid met betrekking tot de vereiste vakkennis en PROFI-competenties.

- Loopbaanmanagement gericht op het vergroten van de interne mobiliteit.

- Ontwikkeling, implementatie en evaluatie van sociale innovaties.

- Het verbeteren van de duurzame inzetbaarheid van het personeel.

- Het ontwikkelen van een wervingsbeleid dat de wervingskracht van de metalektrobedrijven vergroot.

- Betere verspreiding van good practices en HR-tools.

In hoofdstuk 8 wordt deze Agenda voor de toekomst verder uitgewerkt. 



\section{Dynamiek in de Metalektro}

De Nederlandse economie vertoonde in 2010 het hele jaar door een gematigde, maar stabiele groei. Ook in de Metalektro was er meer bedrijvigheid, meer werkgelegenheid en liep het aantal vacatures langzaam op. De innovatiekracht van de sector bleef hoog, ook al werden er in 2010 wat minder innovaties gerealiseerd dan in de jaren daarvoor. Voor 201 verwachten de bedrijven echter de innovaties weer op het hoge niveau van de jaren ervoor te krijgen.

\subsection{Ontwikkelingen in de Metalektro: conjunctuur}

In maart 20II maakte het CBS bekend dat er ook in het vierde kwartaal van 2010 weer sprake was geweest van economische groei. Het was inmiddels het zesde kwartaal op rij met economische groei. Deze cijfers lijken er op te wijzen dat de Nederlandse economie de crisis voorgoed achter zich heeft gelaten. Vergeleken met de jaren voor de crisis, was de gemiddelde groei van I, $8 \%$ in 2010 echter nog vrij gematigd. Al met al is volgens het CBS ongeveer de helft van de historische krimp in 2009 in 2010 weer ongedaan gemaakt. ${ }^{I}$ Nederland profiteerde onder meer van de aantrekkende vraag vanuit de Duitse exportindustrie. De economie van onze Oosterburen groeide, vooral dankzij de export, met 3,6\%. Hiervan kon ook de Nederlandse economie profiteren. Dit geldt in versterkte mate voor de Metalektro. Voor sommige branches binnen de Metalektro trad het herstel al vroeg in. Veel bedrijven hadden in het begin van 2010 al een behoorlijke orderportefeuille opgebouwd. Daarentegen hebben bedrijven in andere branches, bijvoorbeeld aan bouw gerelateerde bedrijven, nog steeds met uitlopers van de crisis te kampen.

De economische ontwikkeling in de Metalektro volgt de algemene conjunctuurontwikkeling in Nederland (zie figuur I.I). Volgens de conjunctuurenquête van het CBS lag het dieptepunt van de crisis voor de Metalektro in het tweede kwartaal van 2009, toen meer dan de helft van de bedrijven aangaf productiebelemmeringen te ondervinden door vraaguitval. Daarna liep het aantal dat met onvoldoende vraag te kampen had gestaag terug. En in het laatste kwartaal van 2010 gaf nog maar 2 op de Io bedrijven aan dat hun productie stagneerde door vraaguitval. Dit zijn echter nog duidelijk meer bedrijven dan voor de crisis, toen slechts I op de Io bedrijven aangaf productiebelemmeringen te ondervinden door een tegenvallende afzet.

I. CBS (20IO), "Economie groeit verder in het vierde kwartal", 24 maart $201 \mathrm{II}$. 
De weer aantrekkende afzet heeft in 2010 ook al weer tot een toename van de werkgelegenheid geleid. Vanwege de betrekkelijk ruime arbeidsmarkt kon het benodigde personeel echter vrij gemakkelijk gevonden worden. In de CBS-cijfers zijn dan ook nog nauwelijks bedrijven te vinden die aangeven dat hun productie belemmerd wordt door personeelstekorten.

\section{Figuur 1.1}

Conjunctuurontwikkeling Metalektro, 2000-2011

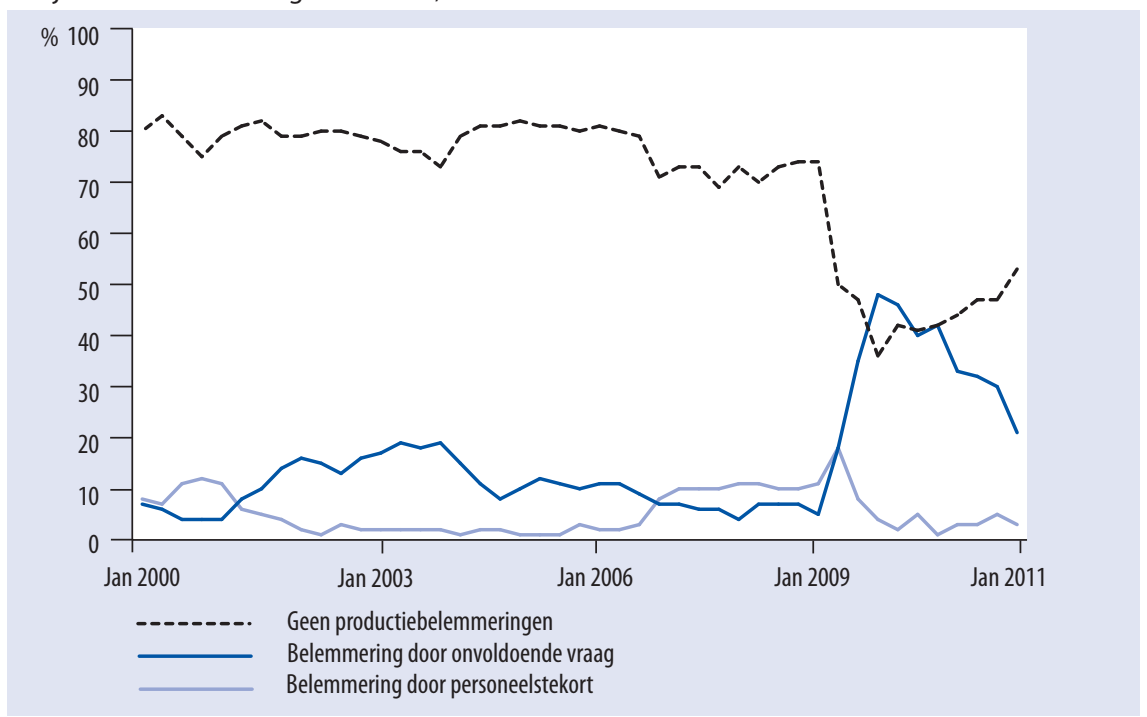

Bron: CBS Conjunctuurtest Industrie 2000-2011 (SBI: 27)

Andere gegevens uit de Arbeidsmarktmonitor Metalektro geven echter wel al aan dat de arbeidsmarkt langzamerhand weer wat krapper wordt. Een eerste indicatie is de toegenomen instroom van nieuwe medewerkers in de Metalektro. Dit terwijl de uitstroom ongeveer op hetzelfde niveau blijft (zie hoofdstuk 2). Dit beeld wordt bevestigd vanuit de vacatures van de tweede meting van 2010 (zie hoofdstuk 3). Ook de tweemaandelijkse Quickscan-cijfers bevestigen deze ontwikkeling in de Metalektro: zowel de werkgelegenheidsindicator als de oplopende gemiddelde vacatureduur wijzen op een krapper wordende arbeidsmarkt (zie paragraaf I.2).

\subsection{De ontwikkeling van de arbeidsmarkt in $\mathbf{2 0 1 0}$}

Figuur I.2 laat zien dat de werkgelegenheid in de Metalektro zich in 2010 herstelt. Het percentage bedrijven dat een krimpende werkgelegenheid rapporteert daalde sterk. Eind 2010 was er nog slechts in IO\% van de bedrijven sprake van een afname van de werkgelegenheid. Daar tegenover staat een duidelijk toename van het aantal bedrijven waar de werkgelegenheid groeide. In de zomer van 2010 was er bij $20 \%$ van 
de bedrijven weer sprake van een groeiende werkgelegenheid. In de maanden daarna nam het aantal bedrijven waarin de werkgelegenheid steeg echter niet verder toe.

Figuur 1.2

Toe- en afname personeel, 2010 (\% bedrijven)

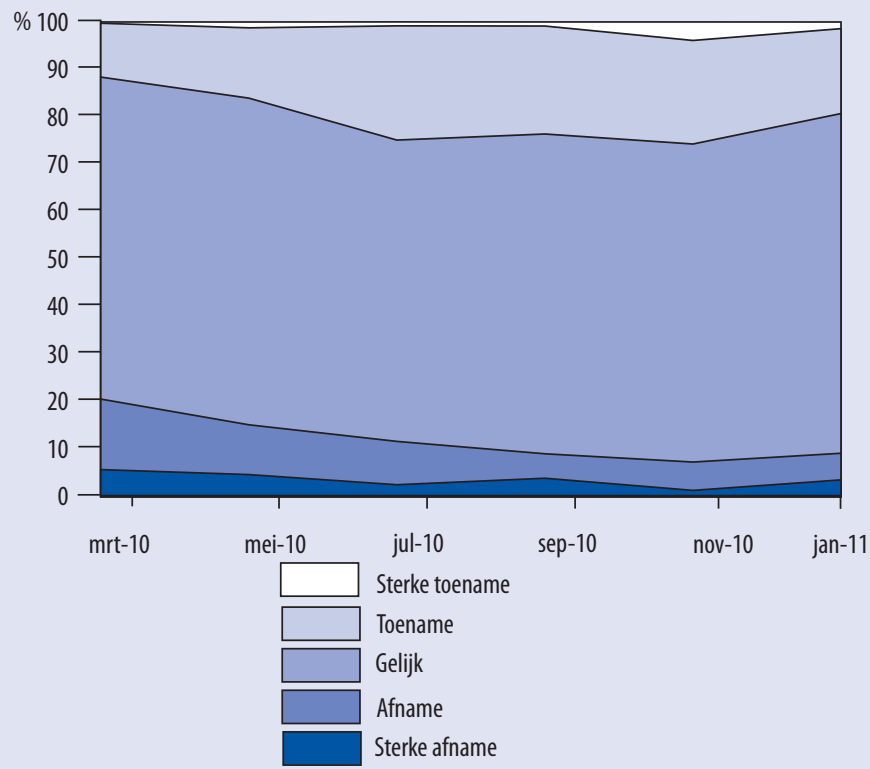

Bron: ROA Quickscanmonitor Metalektro 2010

De groei van de werkgelegenheid komt in het tweede kwartaal van 2010 voornamelijk vanuit de grotere bedrijven met meer dan Ioo medewerkers. Binnen de branches Metaalproducten, en in mindere mate de Elektrotechniek, neemt de werkgelegenheid vanaf het tweede kwartaal weer toe, terwijl er in de Basismetaal en Machinebouw bij de meeste bedrijven nog steeds sprake is van werkgelegenheidskrimp.

In de eerste helft van het jaar, tot de zomer, zet de groei zich voort onder de middelgrote en grote bedrijven. Bij bedrijven met minder dan 50 medewerkers is het aantal krimpende bedrijven nog groter dan het aantal groeiende bedrijven. Ook bij de Transportmiddelen hebben de bedrijven met een krimpende werkgelegenheid nog de overhand. De sterkste werkgelegenheidsgroei komt vanuit de Metaalproducten.

In de tweede helft van het jaar zet deze trend zich voort. Nog altijd zijn het vooral de bedrijven met meer dan 50 medewerkers die de werkgelegenheid in de Metalektro laten groeien. Vooral de bedrijven in de Elektrotechniek, Transportmiddelen en Machinebouw nemen weer nieuw personeel aan. In de Metaalproductenbranche zijn er dan echter nog steeds veel bedrijven waar de werkgelegenheid gelijk blijft. 


\section{Vacatures}

De Quickscan geeft ook een goed beeld van de ontwikkeling van de gemiddelde duur van de openstaande vacatures. Dit is in feite nog een betere indicator voor de krapte op de arbeidsmarkt dan de werkgelegenheidsontwikkeling. Uit figuur I.3 blijkt dat de gemiddelde vacatureduur sinds het begin van 20 Io weer oploopt. Dit is met name goed te zien aan het teruglopen van de vacatures die minder dan 3 maanden openstaan.

\section{Figuur 1.3}

Gemiddelde duur vacatures, 2010 (\% bedrijven)

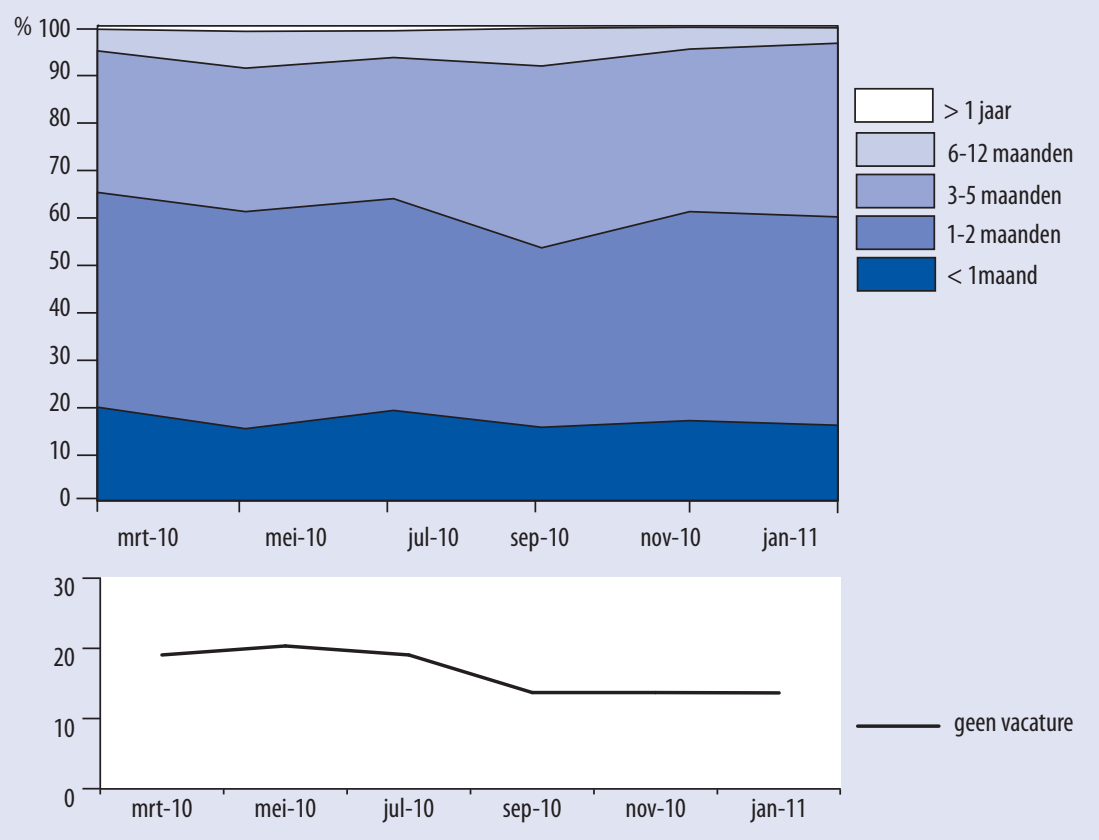

Bron: ROA Quickscanmonitor Metalektro 2010

Lang openstaande vacatures zijn naar verhouding vaker te vinden bij bedrijven in de branches Metaalproducten, Machinebouw en Elektrotechniek. Ook zijn er regionale verschillen merkbaar. In het Westen van het land zijn er meer langer openstaande vacatures dan in de regio's Noord-Oost en Zuid. Wel is er in Noord-Oost een groter aandeel van bedrijven met openstaande vacatures dan in West- of Zuid-Nederland.

Grotere bedrijven hadden in 2010 vaker vacatures die tussen de 2 en 5 maanden openstaan, maar ze hadden minder vaak vacatures die langer dan 6 maanden openstaan. Grotere bedrijven blijken er beter in te slagen om deze vacatures op een redelijke termijn in te vullen dan kleinere bedrijven. Vaak zijn grotere bedrijven voor veel werk- 
nemers aantrekkelijk, waardoor deze bedrijven minder last hebben van een krapper wordende arbeidsmarkt.

\subsection{Structurele werkgelegenheidsontwikkeling}

Door de continue stijging van de arbeidsproductiviteit daalt de werkgelegenheid in de Metalektro al jaren lang. Door de sterke groei van de afzet veranderde de licht dalende trend in de werkgelegenheid in 2007 echter in een lichte stijging van de werkgelegenheid. In de werkgelegenheidscijfers van het CBS, zoals deze in figuur I.4 weergegeven worden, is de situatie tot 2009 weergegeven. Hierbij is het jaar $200 \mathrm{I}$ het basisjaar (werkgelegenheidindex = IOO). In de daarop volgende jaren daalde de werkgelegenheid in de Metalektro volgens het CBS met 20\%. In 2007 steeg de werkgelegenheid echter licht, waarna er in 2009 weer een daling te zien is. ${ }^{2}$

\section{Figuur 1.4}

Ontwikkeling van werkenden in de Metalektro (Index 1996-2009; basisjaar 2001)

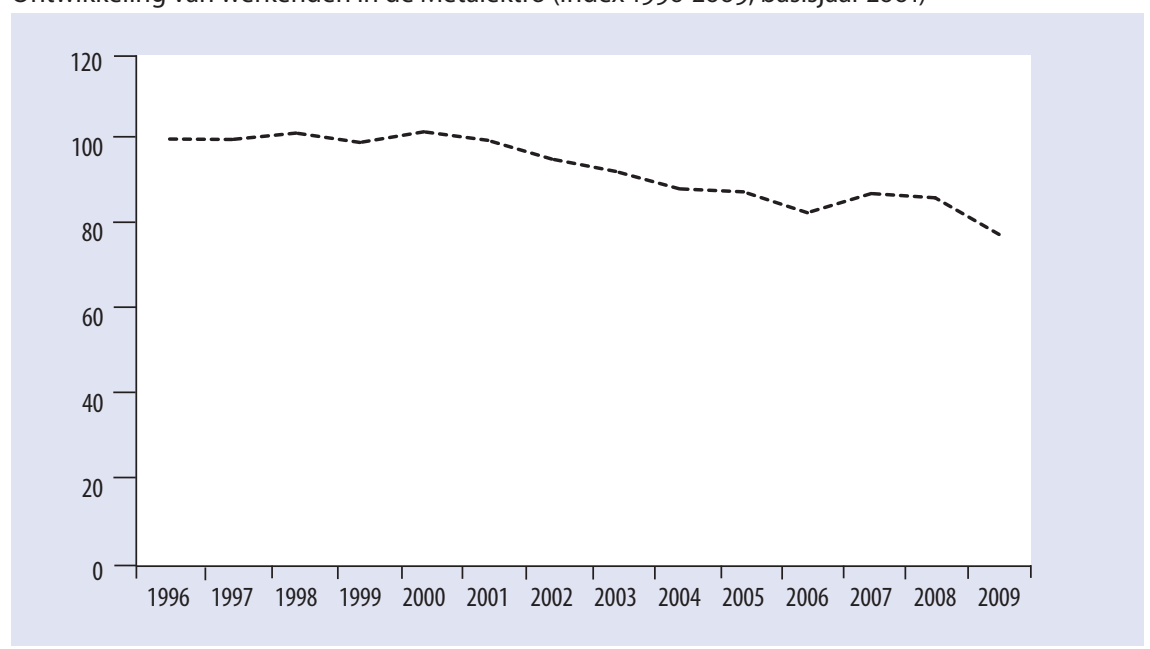

Bron: CBS / Enquête Beroepsbevolking 1996-2009

In de Metalektro werken relatief veel oudere werknemers (zie ook hoofdstuk 6). In 2009 was $24,5 \%$ van de werknemers ouder dan 50 . Daar tegenover staat dat $17 \%$ jonger dan 30 is. De vergrijzing van het personeel is het sterkst in de Basismetaal, waar maar liefst $35 \%$ van de werknemers ouder dan 50 is, terwijl maar I4\% jonger is dan 30 . De 'jongste' branche in de Metalektro is de Metaalproductenbranche. In deze sector is I9\% van de werknemers jonger dan 30 en slechts $22 \%$ ouder dan 50.

2. De CBS-cijfers van de werkgelegenheidsontwikkeling in 2010 zijn nog niet beschikbaar. 
Van de werkenden heeft bijna de helft (47\%) een opleiding op middelbaar niveau (MBO) gevolgd. Minder dan een derde (28\%) is laag opgeleid (VMBO of lager), terwijl $25 \%$ een HBO- of WO-opleiding heeft gevolgd. Het gemiddelde opleidingsniveau is het hoogst in de Elektrotechniek, waar ongeveer $39 \%$ van het personeel hoger opgeleid is. De laagste opleidingsniveaus zijn vooral te vinden in bedrijven in de Metaalproductenbranche waar gemiddeld 37\% laag opgeleid is.

\subsection{Innovatie}

Het percentage bedrijven met technologische innovaties was in 20Io lager dan in 2009, maar zal naar verwachting van de bedrijven zelf in 20 II weer stijgen. Technologische en sociale innovaties zijn van groot belang voor de bedrijven in de Metalektro. Terwijl de technologische innovaties in 2009 ondanks de crisis op peil bleven, namen ze in 2010 iets af. In 2009 had ruim $90 \%$ van de bedrijven minimaal één vorm van technologische innovaties gerealiseerd en in 2010 was dit nog maar bij $80 \%$ van de bedrijven het geval. Deze daling hadden de bedrijven in het Werkgeverspanel Metalektro 2009 al aangekondigd toen zij hun verwachtingen voor 2010 formuleerden. De verwachtingen voor $201 \mathrm{I}$ zijn echter weer optimistischer: $89 \%$ van de bedrijven verwacht in 20II minimaal één innovatie te introduceren.

Figuur 1.5

Technologische innovaties, 2010 (\% bedrijven)

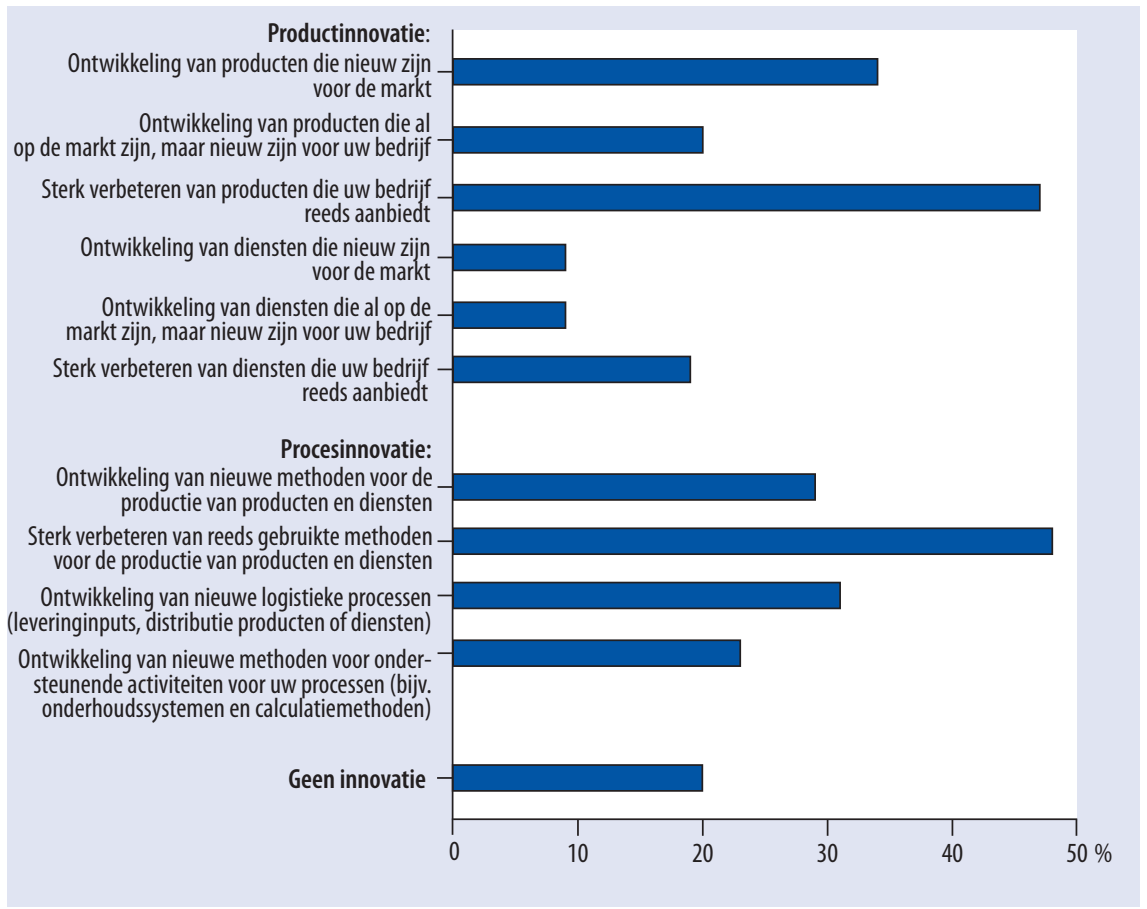

Bron: ROA / Werkgeverspanel Metalektro 2010 
In 2010 hebben de bedrijven zich vooral gericht op het verbeteren van bestaande producten en productieprocessen (zie figuur I.5). De helft van de bedrijven heeft in 2010 één of meerdere producten sterk verbeterd, terwijl ongeveer een derde van de bedrijven volledig nieuwe producten heeft ontwikkeld. Ook bieden steeds meer bedrijven nieuwe of verbeterde diensten aan. Deze trend is al een aantal jaren zichtbaar.

Op het gebied van procesinnovaties waren de metalektrobedrijven in 2010 nog actiever: ongeveer de helft van de bedrijven heeft zijn productieprocessen sterk verbeterd, terwijl ongeveer $30 \%$ zelfs een geheel nieuwe productiemethode heeft geïntroduceerd. Ook werd bij een derde van de bedrijven het productieproces gestroomlijnd met behulp van nieuwe logistieke processen.

\section{Ontwikkeling toekomstige innovaties}

Bedrijven verwachten in $201 \mathrm{I}$ meer te innoveren dan ze in 2010 aan innovaties hebben gerealiseerd. Zorgelijk is echter wel dat er voor de komende vijf jaar een lichte terugloop in de innovatieactiviteit wordt verwacht. Figuur I.6 geeft een overzicht van de verwachtingen die bedrijven hebben over het in de komende vijf jaar introduceren van volledig nieuwe producten, processen en diensten.

\section{Figuur 1.6}

Verwachte innovaties voor de komende vijf jaar (\% bedrijven)

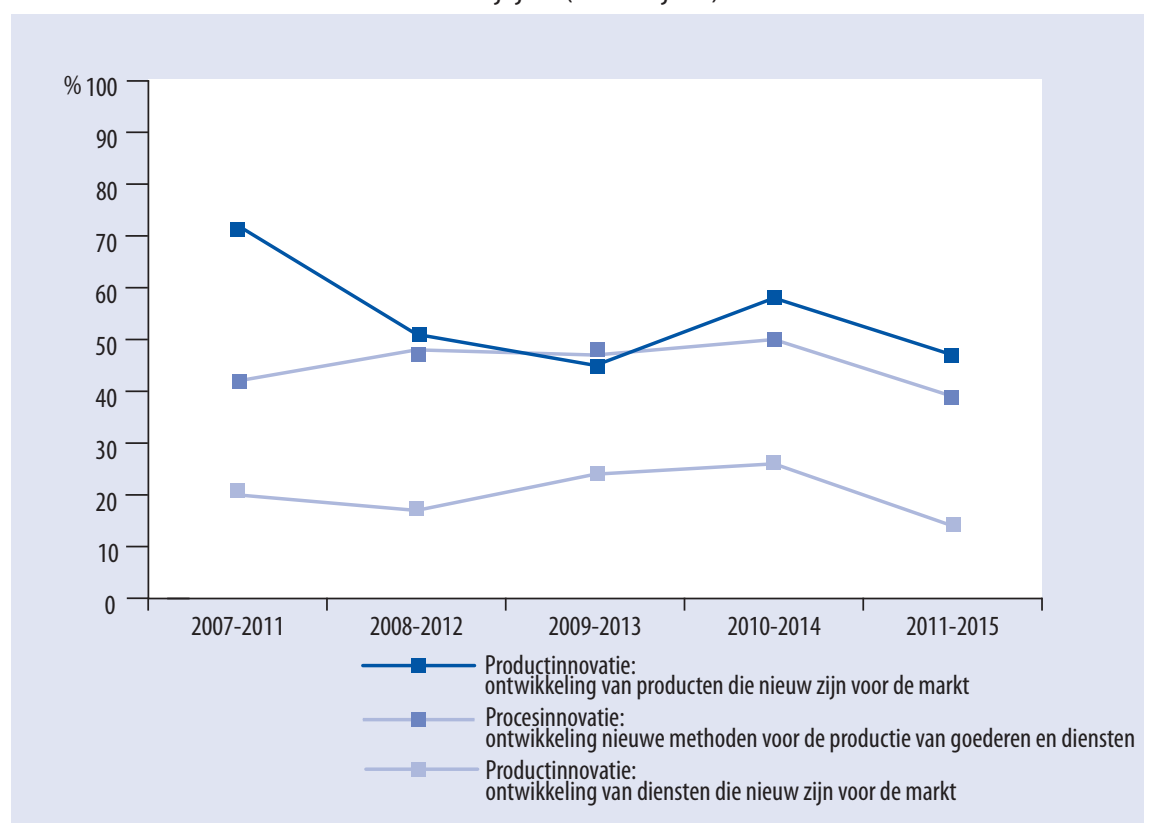

Bron: ROA / Werkgeverspanel Metalektro 2006-2010 
De gegevens komen uit de eindejaarsmetingen van het Werkgeverspanel 2007 tot en met 20I0. Uit de figuur blijkt dat het aantal bedrijven dat verwacht in de nabije toekomst productinnovaties door te voeren na 2007 is afgenomen. Ook de procesinnovaties, waarvan de vijfjaarsverwachting na 2007 toenam, zijn in 2010 teruggevallen op een lager niveau. De verwachtingen over de nieuw te ontwikkelen diensten laten een soortgelijk beeld zien: terwijl deze sinds 2008 toenamen, vlakken deze in 20 Io weer af.

\section{Sociale innovatie}

Naast technologische innovaties zijn ook de sociale innovaties voor de bedrijven in de Metalektro van groot belang. Tweederde van de bedrijven heeft in 2010 een sociale innovatie doorgevoerd. Al sinds enkele jaren neemt het belang van sociale innovaties toe. Bedrijven hadden in 2010 vooral aandacht voor de flexibele inzet van het technisch personeel en het projectmatig werken. Daarnaast zijn taakintegratie en het werken in teams veelgenoemde sociale innovaties van het afgelopen jaar. Hoofdstuk 5 zal hier verder op ingaan. 


\section{Arbeidsmarktontwikkelingen in $\mathbf{2 0 1 0}$}

De arbeidsmarktontwikkeling in 2010 was vrij positief. Vooral bij de uitvoerende technici was er sprake van een flinke instroom. Ruim de helft van de bedrijven heeft personeel in deze functies aangetrokken. In de tweede helft van 2010 waren er in nagenoeg alle functiecategorieën minder bedrijven met krimpende werkgelegenheid dan in de eerste helft van het jaar. De krimp neemt in het bijzonder sterk af in de uitvoerende technische functies.

De bedrijven met een krimpende werkgelegenheid probeerden deze krimp met zachte hand te realiseren door het niet verlengen van tijdelijke contracten, het niet vervangen van werknemers die met pensioen gaan en het invoeren van een vacaturestop. Slechts een kwart van de bedrijven met een krimpende werkgelegenheid kwam er niet onderuit om personeel te ontslaan.

In elke functiecategorie heeft de overgrote meerderheid van de arbeidskrachten een vast contract. Wat echter opvalt, is dat het percentage vaste arbeidskrachten in de tweede helft van het jaar in vrijwel elke functiecategorie afnam. Dit komt doordat bedrijven door het aantrekken van de economie in eerste instantie vooral meer tijdelijke arbeidskrachten aannemen. Pas wanneer er meer zekerheid bestaat over de positieve economische vooruitzichten op de iets langere termijn mag verwacht worden dat veel bedrijven weer overgaan tot het aanbieden van vaste contracten.

\subsection{De personeelsinstroom ${ }^{3}$ in $\mathbf{2 0 1 0}$}

Hoe heeft de personeelsinstroom zich ontwikkeld in 2010 en zijn er hierbij verschillen waarneembaar tussen de eerste en tweede helft van het jaar? En om welke functiecategorieën gaat het dan met name? Figuur 2.I toont per functiecategorie het percentage bedrijven dat aangeeft nieuwe werknemers in dienst te hebben genomen.

3. De personeelsinstroom in de Metalektro heeft alleen betrekking op nieuwe werknemers met een dienstverband. Het gaat hier dus niet om uitzendkrachten of personen die werken in detacheringconstructies. Laatstgenoemden komen aan bod in paragraaf 2.4 . 
De meeste bedrijven hebben personeel aangenomen in de uitvoerende technische functies. In zowel de eerste als de tweede helft van 20 Io heeft ruim 50\% van de bedrijven uitvoerende technici in dienst genomen. Ook het percentage bedrijven dat nieuwe technisch opgeleide verkopers heeft aangetrokken, bleef min of meer constant (circa I op de 5 bedrijven). In alle andere functiecategorieën namen in de tweede helft van het jaar duidelijk meer bedrijven personeel aan dan in de eerste helft. Vooral de stijging van het aantal bedrijven dat leidinggevend en ondersteunend niet-technisch personeel in dienst nam, is aanzienlijk. In laatstgenoemde functiecategorie verdubbelde het percentage bedrijven dat nieuw personeel aantrok zelfs binnen enkele maanden. Ten opzichte van het niveau in 2009 , waarin er nauwelijks sprake was van nieuwe personeelsinstroom, laten deze cijfers duidelijk zien dat de personeelsinstroom in de Metalektro weer aantrekt.

Figuur 2.1

Bedrijven met instroom naar functiecategorie (\% bedrijven), 2010

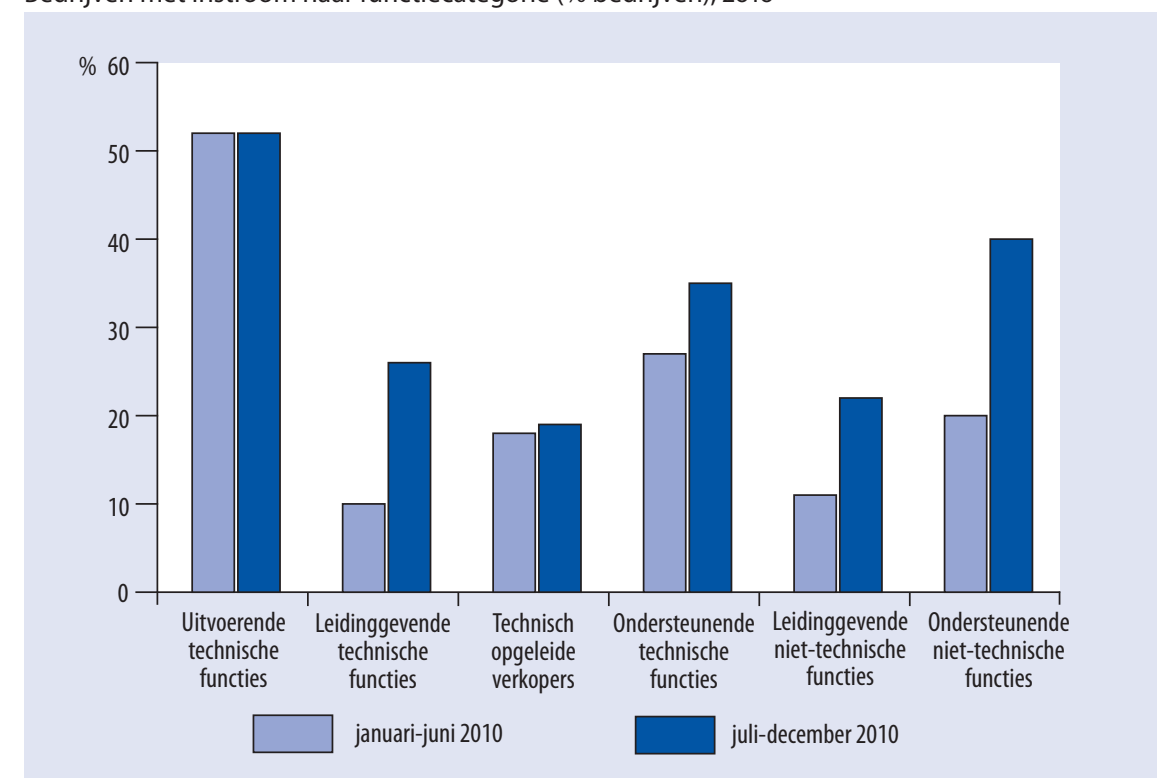

Bron: ROA / Werkgeverspanel Metalektro 2010

Figuur 2.2 geeft een overzicht van de ontwikkeling van het percentage bedrijven dat uitvoerend technisch personeel in dienst nam in de periode 2005-20I0. In deze jaren trok gemiddeld genomen $60 \%$ van de bedrijven nieuw uitvoerend technisch personeel aan. In de tweede helft van 2006 bereikte het percentage bedrijven dat nieuwe uitvoerende technici aantrok met bijna $80 \%$ het hoogste punt. In 2007 en 2008 schommelde dit percentage rond de $70 \%$. In de eerste helft van 2009 zorgde de economische crisis voor een enorme daling van het percentage bedrijven dat nieuw personeel aantrok met maar liefst 30\%-punt. Daarna herstelde de economie zich weer enigszins, al wordt het niveau van vóór de crisis nog lang niet bereikt. Zoals we eerder zagen, nam in de 
eerste helft van 2010 iets meer dan de helft van de bedrijven weer nieuwe uitvoerende technici in dienst en stabiliseert dit zich gedurende de tweede helft van het jaar.

Figuur 2.2

Bedrijven met instroom van uitvoerend technisch personeel (\% bedrijven), 2005- 2010

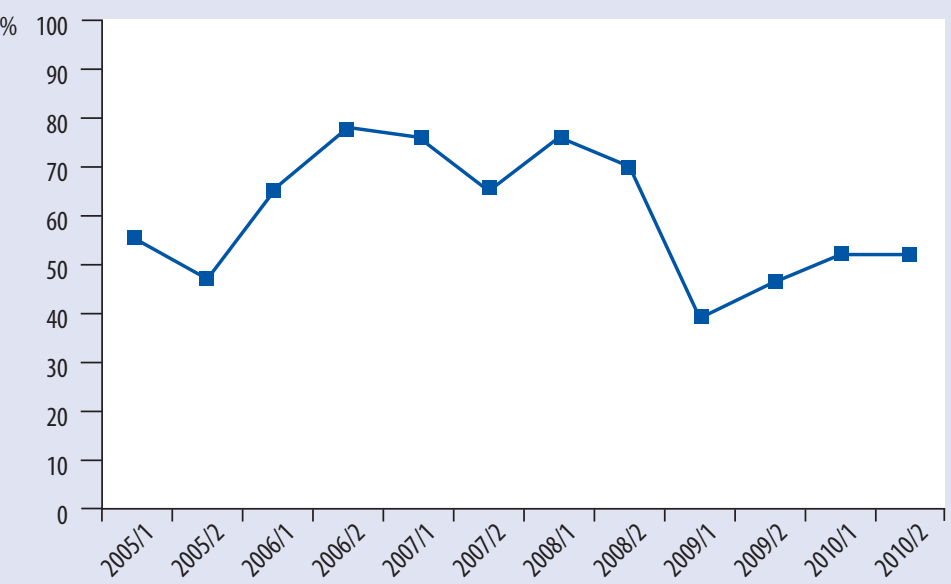

Bron: ROA / Werkgeverspanel Metalektro 2005-2010

\section{Zoeken naar de optimale verhouding vast personeel versus flexibele schil}

Om toekomstige reorganisaties als gevolg van conjuncturele schommelingen te voorkomen, hebben diverse bedrijven een in omvang stabiele groep vaste medewerkers met daaromheen een flexibele schil. Een verhouding van 1:1 tussen de vaste kern en de flexibele schil bleek bij een bedrijf te veel inefficiënties in het werkproces met zich mee te brengen. Nu wordt er gestreefd naar een verhouding van 3:1 tot maximaal 2:1.

De meeste bedrijven vinden dat er náást een kern van vast personeel een flexibele schil moet bestaan. Zo'n driekwart van de bedrijven is het eens met de Quickscan-stelling "De combinatie van personeel in vaste dienst met een flexibele schil biedt voordelen boven het flexibel maken van alle arbeidscontracten" (Quickscan November 2010). Eén van de bedrijven beargumenteerde deze voorkeur als volgt: Voor een organisatie die, net als het Concertgebouworkest, continu op een hoog niveau moet acteren, is het van belang dat mensen lange tijd in de organisatie werken om kennis en ervaring op te doen door fouten te maken en deze weer te corrigeren. Dit is alleen mogelijk als voldoende mensen langere tijd in de organisatie werken. Vandaar dat de meeste metalektrobedrijven, ondanks de grote fluctuaties die er kunnen optreden in hun afzet, kiezen voor een combinatie van personeel in vaste dienst en in de flexibele schil. 


\subsection{De personeelsuitstroom ${ }^{4}$ in $\mathbf{2 0 1 0}$}

Figuur 2.3 laat voor elk van de zes functiecategorieën zien welk deel van de bedrijven in 2010 werknemers zag vertrekken. Ook in deze figuur wordt weer onderscheid gemaakt tussen de meting over de eerste helft van 2010 en de meting over de tweede helft van het jaar. Uit de figuur blijkt dat er in de tweede helft van 2010 in alle functies een toename was van het aantal bedrijven met personeelsuitstroom. De meeste bedrijven geven aan dat er personeel uit de uitvoerende technische functies vertrokken is. In de eerste helft van 2010 gaf ruim 50\% van de bedrijven aan dat er personeel uit deze functies was uitgestroomd en in de tweede helft van het jaar nam dit toe tot bijna $60 \%$ van de bedrijven. Verder is het opvallend dat de uitstroom onder leidinggevenden in de tweede helft van 2010 sterk is toegenomen. Het percentage bedrijven dat aangeeft dat er bij hen sprake is van uitstroom van leidinggevenden is zowel bij de technische als bij de niet-technische functies in korte tijd verdubbeld. Ook bij de ondersteunende niet-technische functies was er in de tweede helft van het jaar sprake van een flinke stijging van het aantal bedrijven met uitstroom $(+17 \%)$.

Figuur 2.3

Bedrijven met uitstroom naar functiecategorie (\% bedrijven), 2010

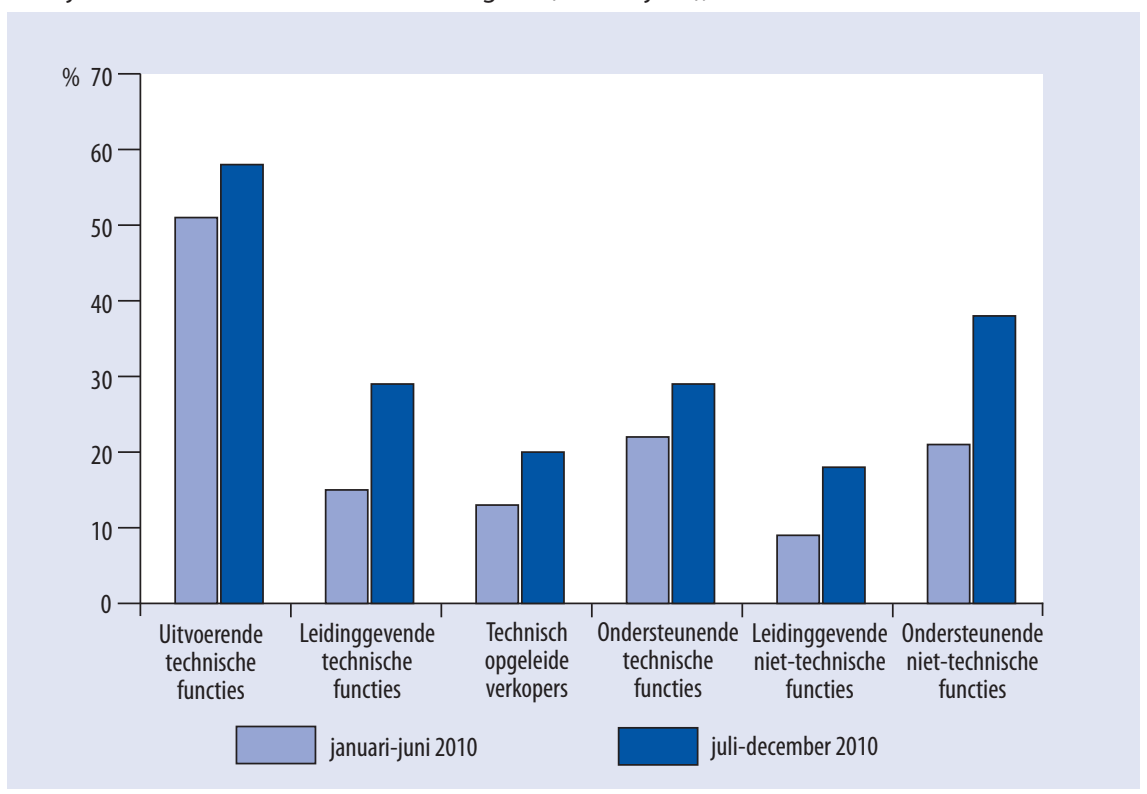

Bron: ROA / Werkgeverspanel Metalektro 2010

4. De personeelsuitstroom in de Metalektro heeft alleen betrekking op vertrokken werknemers die bij bedrijven in deze sector in dienst waren. Het gaat hier dus niet om uitzendkrachten of personen die in detacheringconstructies binnen het bedrijf werkten. Deze komen aan bod in paragraaf 2.4 
Figuur 2.4 geeft voor de periode 2005-20I0 weer welk deel van de bedrijven personeel zag vertrekken uit de uitvoerende technische functies. Gemiddeld had 63\% van de bedrijven personeelsuitstroom in deze functiecategorie. Uit de figuur blijkt dat het percentage bedrijven dat te kampen had met uitstromende uitvoerende technici tot de tweede helft van 2006 toenam. Hoewel dit percentage in 2007 weer afnam, bereikte het percentage bedrijven met uitstroom in deze functiecategorie in de eerste helft van 2008 zijn hoogste punt. Op de krappe arbeidsmarkt die er op dat moment was, zag driekwart van de bedrijven technisch personeel vertrekken. Het is opmerkelijk dat de economische crisis die eind 2008 inzette niet heeft geleid tot een sterke toename van de personeelsuitstroom in de metalektrobedrijven. Integendeel, vanaf het moment dat de crisis inzette is er sprake van een geleidelijke daling van het percentage bedrijven met uitstroom van uitvoerende technici. Dit wijst er op dat de ontwikkeling van de personeelsuitstroom met name door het vrijwillige verloop wordt bepaald. Recentelijk is het percentage bedrijven met personeelsuitstroom weer gestegen en geven bijna 6 op de Io bedrijven aan dat er in de tweede helft van 2010 sprake was van personeelsuitstroom onder uitvoerende technici.

Figuur 2.4

Bedrijven met uitstroom bij uitvoerend technisch personeel (\% bedrijven), 2005- 2010

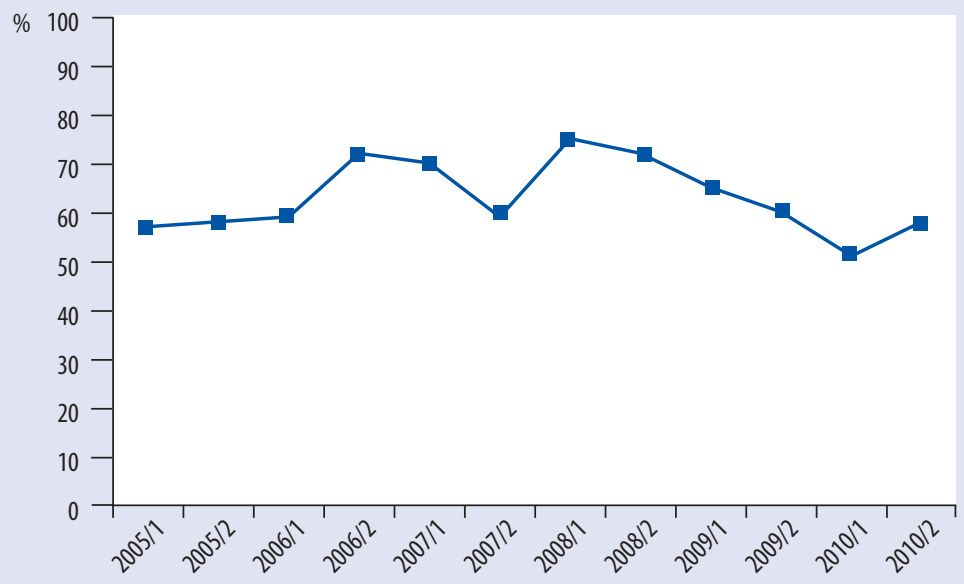

Bron: ROA / Werkgeverspanel Metalektro 2005-2010

\subsection{Werkgelegenheidsontwikkelingen in $\mathbf{2 0 1 0}$}

Naast de ontwikkelingen op het gebied van personeelsinstroom en -uitstroom is de bedrijven in de Metalektro ook gevraagd of zij in 2010 te kampen hadden met krimpende werkgelegenheid. Hierbij wordt opnieuw een onderscheid gemaakt tussen de verschillende functiecategorieën. Uit figuur 2.5 blijkt dat het percentage bedrijven met 
een krimpende werkgelegenheid in het tweede deel van 2010 in nagenoeg alle functiecategorieën is afgenomen. De enige uitzondering hierop vormen de ondersteunende niet-technische beroepen, waarin iets meer bedrijven een krimpende werkgelegenheid rapporteerden. De krimp nam in het bijzonder sterk af in de uitvoerende technische functies. Terwijl in de eerste helft van 2010 nog $28 \%$ van de bedrijven in de Metalektro aangaf dat zij te kampen had met een krimpende werkgelegenheid in deze functies, was dit in de tweede helft van het jaar nog slechts $8 \%$ van de bedrijven. Dit wijst er op dat, zeker in vergelijking met de eerste helft van 2009, bedrijven in de Metalektro de ergste klappen van de crisis langzamerhand te boven komen.

\section{Figuur 2.5}

Bedrijven met krimpende werkgelegenheid naar functiecategorie (\% bedrijven), 2010

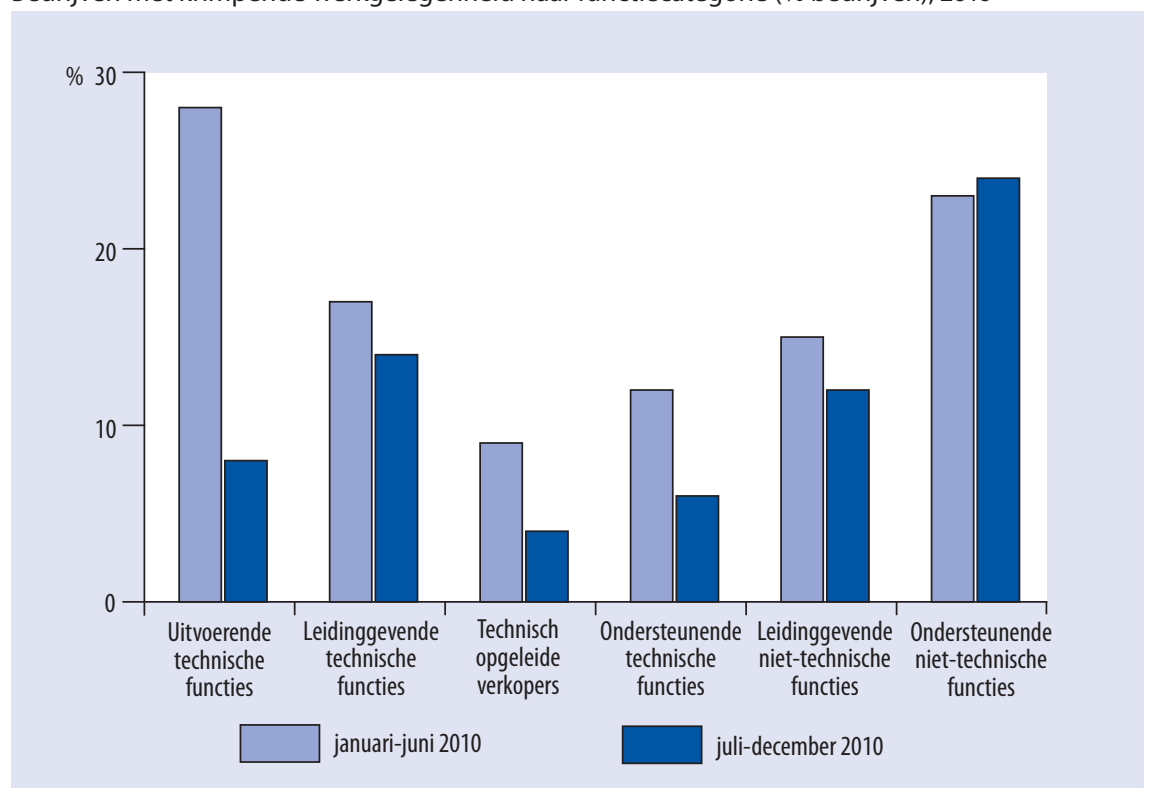

Bron: ROA / Werkgeverspanel Metalektro 2010

Aan de bedrijven die aangaven te kampen hebben met krimpende werkgelegenheid voor technisch personeel is ook gevraagd welke gevolgen dit had binnen het bedrijf. Figuur 2.6 laat zien dat de krimpende werkgelegenheid onder technisch personeel er het vaakst toe leidde dat tijdelijke contracten niet verlengd werden. Van alle bedrijven met krimp gaf $61 \%$ aan deze maatregel te hebben moeten nemen. Andere veelgenoemde maatregelen om de werkgelegenheidskrimp met zachte hand te kunnen realiseren, zijn het niet vervangen van werknemers die met pensioen gaan en het invoeren van een vacaturestop. Beide maatregelen werden eveneens door zo'n 6 op de Io bedrijven met werkgelegenheidskrimp genomen. 
Daarnaast stimuleerde een kwart van de bedrijven waar de werkgelegenheid krimpt hun werknemers om eerder met pensioen te gaan. Een even grote groep plaatste medewerkers over naar andere functies binnen het bedrijf. Bij I8\% van de bedrijven werd de krimp ook gerealiseerd door werknemers die het bedrijf op eigen initiatief verlaten, terwijl in $15 \%$ van de bedrijven met een krimpende werkgelegenheid werknemers gestimuleerd werden om een andere baan te zoeken. Al met al blijkt slechts een kwart van de bedrijven met een krimpende werkgelegenheid er niet onderuit te komen om personeel te ontslaan.

Figuur 2.6

Gevolaen van krimpende werkaeleaenheid (\% bedriiven met krimpende werkaeleaenheid), 2010

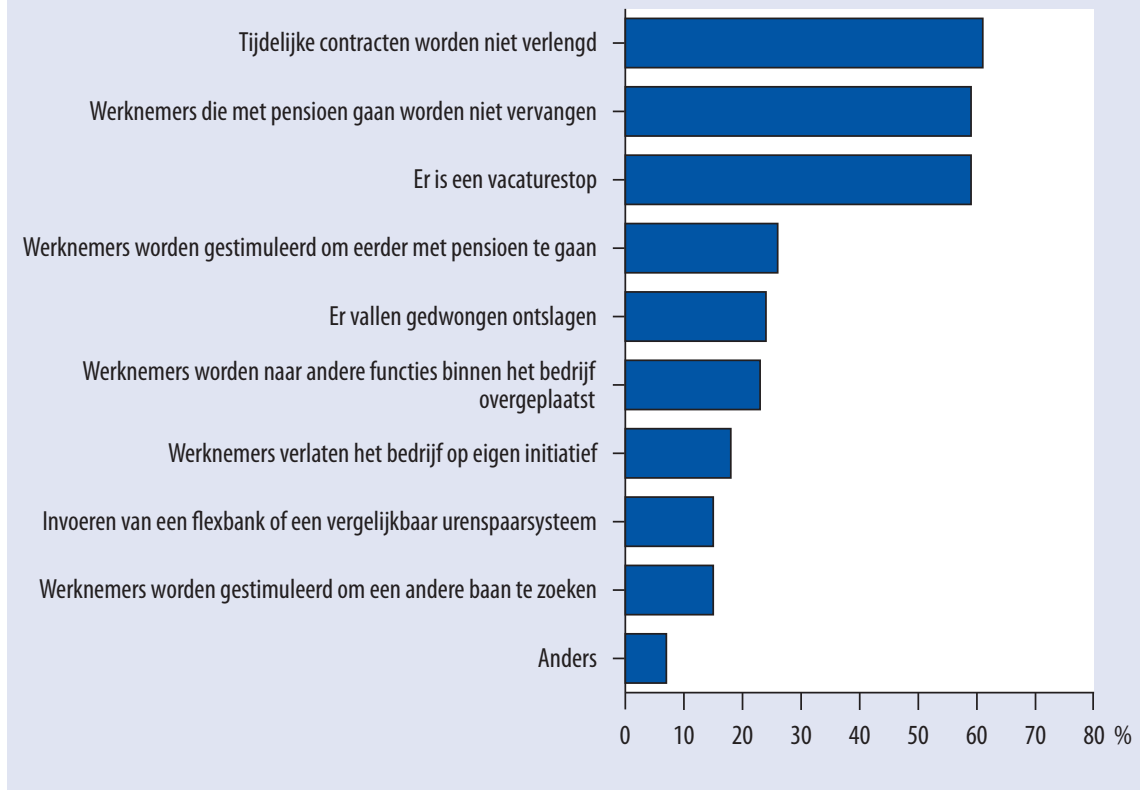

Bron: ROA / Werkgeverspanel Metalektro 2010

\subsection{Opbouw personeelsbestand in de Metalektro}

Arbeidskrachten in de Metalektro kunnen in vaste loondienst werken, in tijdelijke loondienst werken of ingeschakeld worden zonder in dienst te zijn bij het bedrijf (bijvoorbeeld uitzendkrachten en gedetacheerden). Figuur 2.7 laat zien dat in elke functiecategorie de overgrote meerderheid van het personeel een vast contract heeft. In de tweede helft van 2010 nam het percentage medewerkers dat in vaste dienst is echter in elke functiecategorie af. Dit lijkt op het eerste gezicht misschien tegenstrijdig, aangezien we eerder zagen dat er in de tweede helft van 2010 juist minder bedrijven waren met een krimpende werkgelegenheid. Echter, als de economie net weer uit het dal omhoog kruipt, kiezen bedrijven er - met het oog op de nog onze- 
kere toekomst - doorgaans voor om allereerst tijdelijke werknemers aan te trekken. Doordat er extra werknemers in tijdelijke loondienst en uitzendkrachten of gedetacheerden aangetrokken worden, stijgt het percentage medewerkers met een flexibel contract. Dit betekent dan ook niet dat het aantal werknemers in vaste dienst is afgenomen.

\section{Figuur 2.7}

Verdeling van het type dienstverband naar functiecategorie, 2010

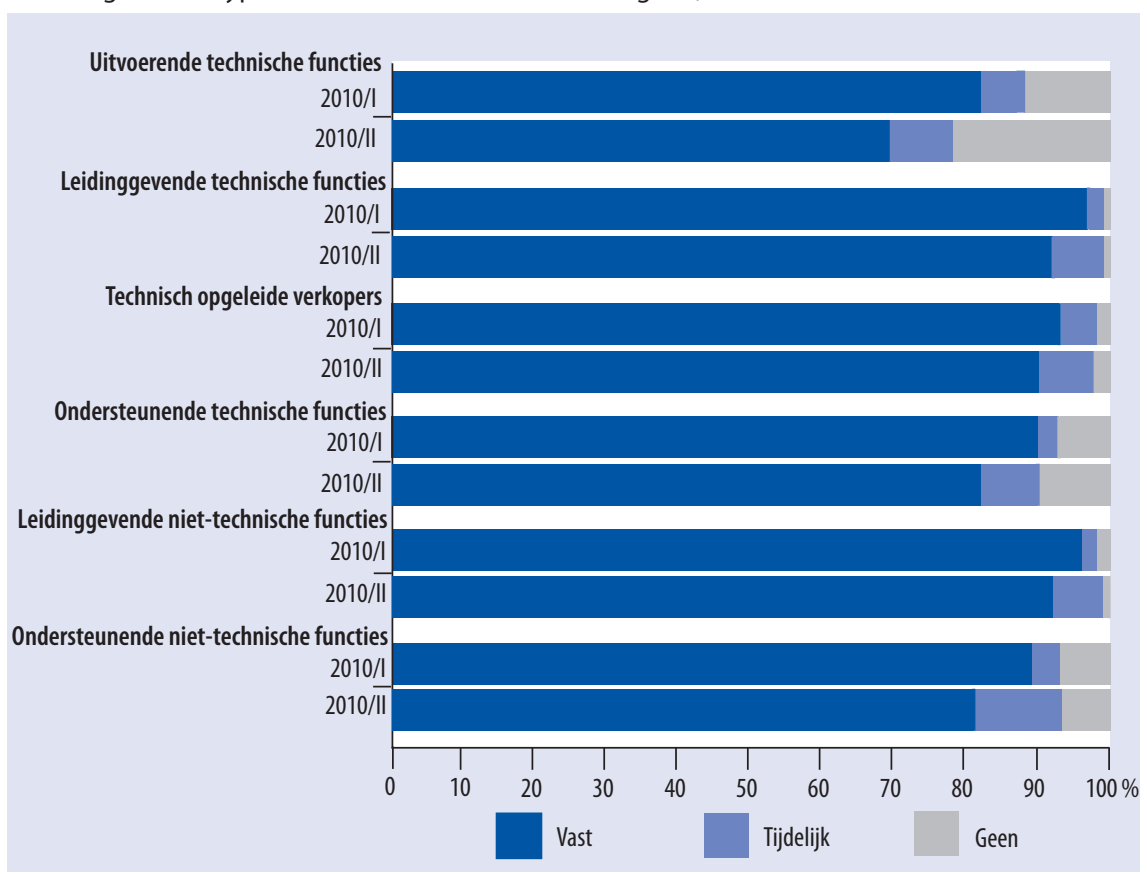

Bron: ROA / Werkgeverspanel Metalektro 2010

Leidinggevenden werken het vaakst in vaste dienst, al neemt ook in deze functies het percentage medewerkers met een vast contract in de tweede helft van jaar enigszins af (92\%). Dit komt waarschijnlijk doordat er extra leidinggevenden worden aangetrokken die in eerste instantie een tijdelijk contract krijgen. Wanneer blijkt dat deze goed functioneren en het herstel van de economie doorzet, krijgen zij waarschijnlijk alsnog een vast contract. Van de technisch opgeleide verkopers heeft ook 90\% een vast contract. Hetzelfde geldt voor degenen die werkzaam zijn in een ondersteunende functie. Bij de uitvoerende technici is het percentage vaste werknemers in de tweede helft van 2010 het meest afgenomen (-13\%-punt), al heeft ook dan nog altijd ruim tweederde van het personeel in deze functies een vast contract (69\%). Deze ontwikkeling laat echter duidelijk zien dat vooral in de uitvoerende technische functies de flexibele schil weer wordt opgebouwd. Dit komt vooral door een sterke toename van het aantal arbeidskrachten zonder dienstverband. In de eerste helft van 20 Io was de 
groep uitzendkrachten en gedetacheerden in deze functies al relatief groot (I2\%), maar in de tweede helft van het jaar nam dit verder toe tot $22 \%$ van het totale personeelsbestand in deze functies. In de ondersteunende niet-technische beroepen zien we in de tweede helft van 2010 de grootste stijging van het percentage medewerkers met een tijdelijk contract (+8\%-punt).

\section{Een grotere flexibele schil: een kwestie van vraag én aanbod?}

Het vergroten van een flexibele schil ten koste van het aantal werknemers met een vast contract wordt enerzijds veroorzaakt door de trend dat bedrijven bepaalde specialistische kennis slechts gedurende een bepaalde tijd nodig hebben. Anderzijds is het nog maar de vraag of werknemers zich nog wel en masse aan één bedrijf willen verbinden door middel van een vaste aanstelling, zeker als de arbeidsmarkt weer krapper wordt. 



\section{Vacatures en werving van personeel}

In dit hoofdstuk zal uitgebreid worden ingegaan op de vacatureontwikkeling en personeelswerving in de Metalektro. In 2010 nam het aantal openstaande vacatures verder toe en in de tweede helft van het jaar stond al weer ruim een derde van de vacatures langer dan 3 maanden open. Daardoor is er weer sprake van een lichte toename van het aantal bedrijven dat met wervingsproblemen voor technisch personeel kampt. De meest genoemde oorzaak voor deze wervingsproblemen is een mismatch tussen de door sollicitanten aangeboden en door bedrijven gevraagde competenties. Wervingsproblemen resulteren in extra werkdruk op de werkvloer. Hierdoor kunnen opdrachten soms niet of niet tijdig afgerond worden. Werkgevers bleken in 2010 met name weer problemen te ondervinden bij het invullen van vacatures voor uitvoerend technisch personeel. Ook zien we dat de arbeidsmarktkrapte in de tweede helft van het jaar toeneemt.

De keuze van de wervingskanalen blijkt sterk afhankelijk te zijn van de functie. Uitzendbureaus worden vaak gebruikt voor het invullen van vacatures voor uitvoerend en ondersteunend technisch personeel, terwijl commerciële werving-en selectiebureaus succesvolle zoekkanalen zijn voor het werven van leidinggevend technisch personeel en technisch opgeleide verkopers

\subsection{Vacatures}

Vacatures geven een goede indicatie van de arbeidsmarktkrapte in een sector. In hoofdstuk I was reeds te zien dat de gemiddelde duur van de vacatures in de loop van 2010 duidelijk is toegenomen. De cijfers van de halfjaarmetingen bevestigen dit resultaat. Het aantal bedrijven met openstaande vacatures is duidelijk gestegen ten opzichte van het historische dieptepunt in 2009. 
Figuur 3.1

Bedrijven met openstaande vacatures naar functiecategorie (\% bedrijven), 2010

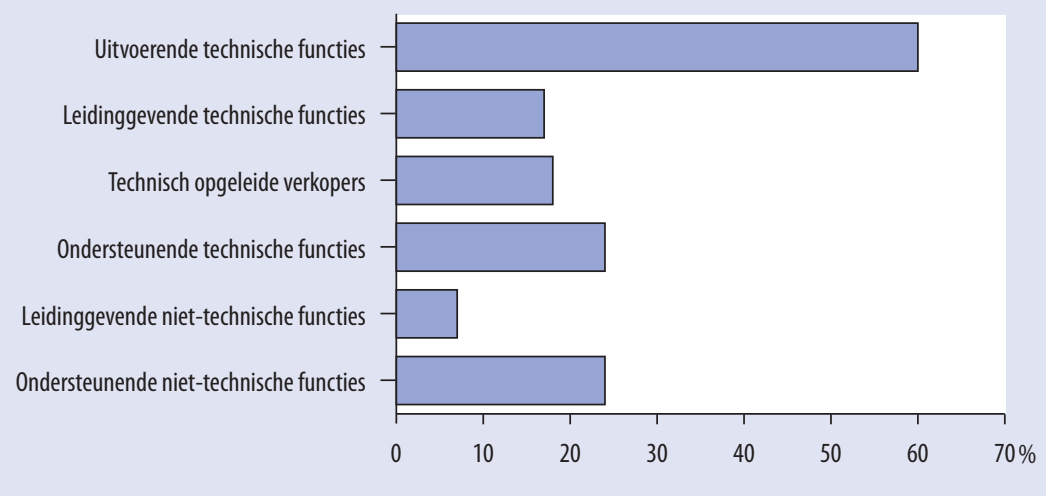

Bron: ROA / Werkgeverspanel Metalektro 2010

Figuur 3.I laat zien welk deel van de bedrijven in de Metalektro in de eerste helft van 2010 in de verschillende soorten functies openstaande vacatures had. Het grootste deel van de bedrijven blijkt op zoek te zijn naar uitvoerende technici: 6 op de Io rapporteert voor het eerste deel van 2010 openstaande vacatures voor deze functies. Bovendien waren bij circa I op de 4 bedrijven in die periode vacatures voor technisch of niet-technisch ondersteunend personeel. Minder dan $20 \%$ van de bedrijven had in het eerste deel van het jaar openstaande vacatures voor technisch opgeleide verkopers en leidinggevenden in technische functies. Van alle onderscheiden functiecategorieën zochten de metalektrobedrijven het minst naar leidinggevenden in niet-technische functies: slechts $7 \%$ gaf aan dergelijke vacatures te hebben gehad.

Als we de cijfers verbijzonderen naar regio, dan zien we dat er in West-Nederland relatief gezien minder vacatures zijn voor uitvoerende technici en juist meer vacatures voor leidinggevende technici. In het Noorden en Oosten van het land zijn er juist relatief weinig vacatures voor leidinggevende technici, terwijl er in het Zuiden relatief weinig openstaande vacatures zijn voor technisch opgeleide verkopers.

\section{Duur}

Hoewel het percentage bedrijven met openstaande vacatures een eerste indicatie geeft van de arbeidsmarktkrapte in de Metalektro, zegt dit natuurlijk niet alles. Daarom is het ook belangrijk om te kijken hoe lang de vacatures gemiddeld open staan. Als bedrijven er immers vrij snel in slagen om geschikt personeel te vinden dan wijst dit op een ruime arbeidsmarkt, terwijl moeilijk vervulbare vacatures wijzen op een krappe arbeidsmarkt. Het oplopen van de gemiddelde vacatureduur naar 3 maanden is daarom een duidelijke indicatie voor de weer toenemende krapte op de arbeidsmarkt. 
Figuur3.2geefteen beeldvan delange-termijn ontwikkelingvan hetvacatureverloopvoor het technisch personeel in de Metalektro. Uit de figuur blijkt dat in de tweede helft van 2005 de vacatures het snelst ingevuld werden. Destijds stond nagenoeg 90\% van allevacatures minder dan drie maanden open. Dit geeft aan dat er toen sprake was van een ruime arbeidsmarkt, waarin bedrijven weinig moeite hebben om hun vacatures in te vullen. In enkele jaren tijd nam het percentage kort openstaande vacatures vervolgens flink af.

In de tweede helft van 2008 waren er door de snel teruglopende werkgelegenheid opeens minder openstaande vacatures. Wat dat betreft is het zeer opmerkelijk dat, zoals figuur 3.2 laat zien, veel bedrijven toen juist meer moeite hadden om de vacatures die open stonden in te vullen. Slechts 2 op de Io bedrijven slaagden er destijds in om deze vacatures binnen één of twee maanden in te vullen, terwijl meer dan de helft van de bedrijven hier zelfs langer dan een half jaar voor nodig had. Vanaf de eerste helft van 2009 neemt het percentage vacatures dat snel kon worden ingevuld echter weer sterk toe. Deze ontwikkeling gaat door tot de eerste helft van 20 o.

\section{Figuur 3.2}

Duur openstaande vacatures voor technisch personeel (\% van totaal aantal vacatures), 2005-2010

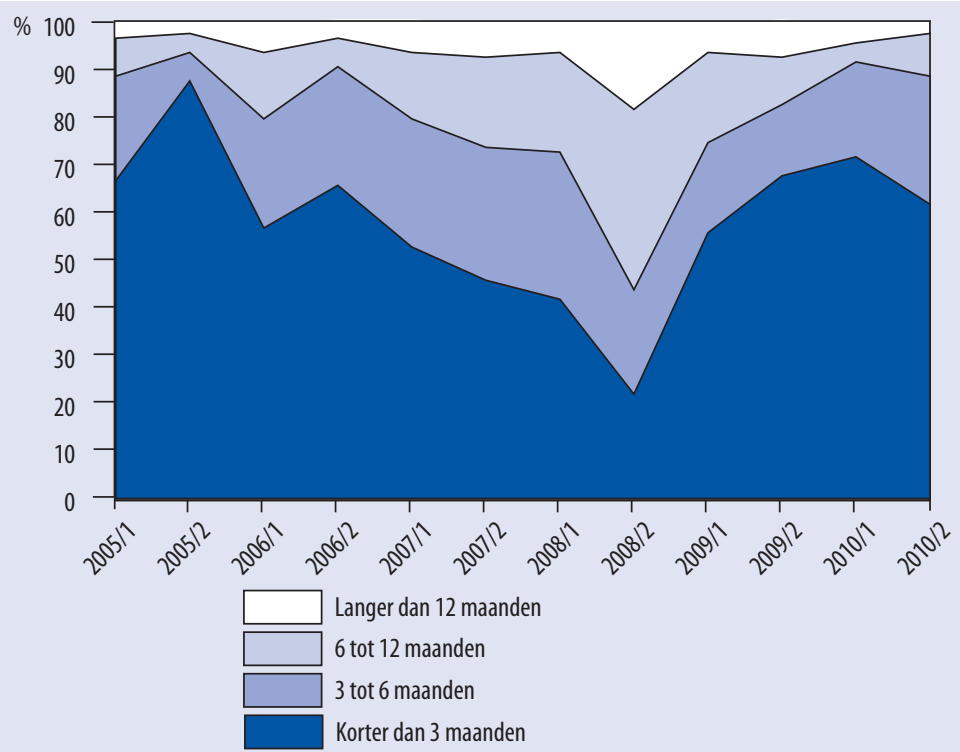

Bron: ROA / Werkgeverspanel Metalektro 2005-2010

In de zomer van 2010 gaf $70 \%$ van de bedrijven aan dat hun vacatures gemiddeld minder dan 3 maanden open stonden. In de tweede helft van 2010 nam het aantal openstaande vacatures verder toe, maar het percentage vacatures dat korter dan drie maanden open stond daalde, waardoor al weer ruim een derde van de vacatures langer dan 3 maanden open stond. Dit laat zien dat de arbeidsmarktkrapte weer toeneemt, al kan er nog steeds van een ruime arbeidsmarkt worden gesproken. 
Wanneer we kijken naar de regionale verschillen in de duur van de openstaande vacatures, dan blijkt dat in beide metingen in 2010 Zuid-Nederland de meeste kort openstaande vacatures ( $<3$ maanden) heeft. Daar stond in de eerste helft van $201082 \%$ van de vacatures minder dan drie maanden open, en in de tweede helft van 20 Io was dit $76 \%$.

\section{Functiecategorie}

Figuur 3.3 laat zien dat circa $60 \%$ van het totaal aantal vacatures dat in 20 Io open stond betrekking had op uitvoerende technici.5 De figuur laat ook zien dat slechts I op de 8 vacatures betrekking had op de (leidinggevende en ondersteunende) niettechnische functies.

\section{Figuur 3.3}

Verdeling totaal aantal openstaande vacatures over functiecategorieën, 2010

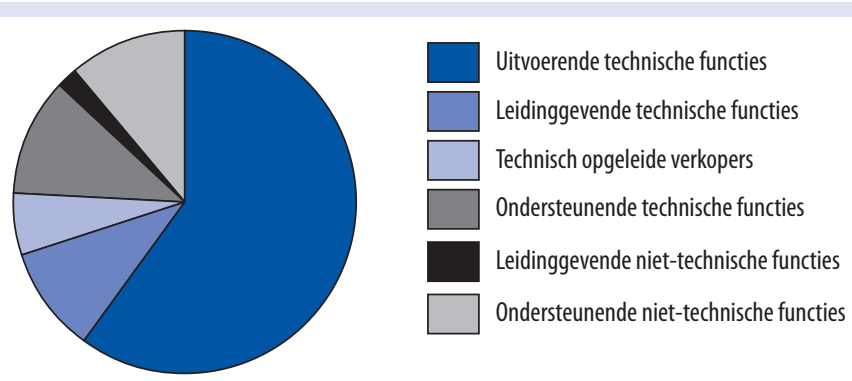

\section{Bron: ROA / Werkgeverspanel Metalektro 2010}

In 20 Io heeft het grootste deel van de vacatures dus betrekking op uitvoerende technische functies. Maar om welk type vacatures gaat het hier nu precies? In figuur 3.4 wordt hier dieper op ingegaan. Zo wordt een gedetailleerder beeld verkregen van vraag en aanbod in deze omvangrijke functiecategorie. Binnen de uitvoerende technische functies was er veel vraag naar lassers. Ook hadden metalektrobedrijven nog regelmatig vacatures voor de machinaal verspanende beroepen, plaatverwerkende beroepen, montage-beroepen, pijpverwerkende beroepen, bankwerk-beroepen en elektromonteurs. Opmerkelijk genoeg bleek het in de tweede helft van 20 Io met name moeilijk te zijn om laag en ongeschoold technisch personeel aan te trekken. Dit zijn technici die een opleiding gevolgd hebben op VMBO-niveau of lager. Daarnaast was er nog een flink aantal vacatures in de categorie 'overige geschoolde technische vaklieden'.

5. Terwijl figuur 3.I voor elke functiecategorie weergeeft welk percentage bedrijven voor deze functies vacatures had openstaan, laat figuur 3.3 zien welk deel van het totaal aantal openstaande vacatures tot een bepaalde functiecategorie behoort. Deze percentages tellen dus op tot Ioo\%. 
Figuur 3.4

Aantal openstaande vacatures voor uitvoerende technische functies, 2010

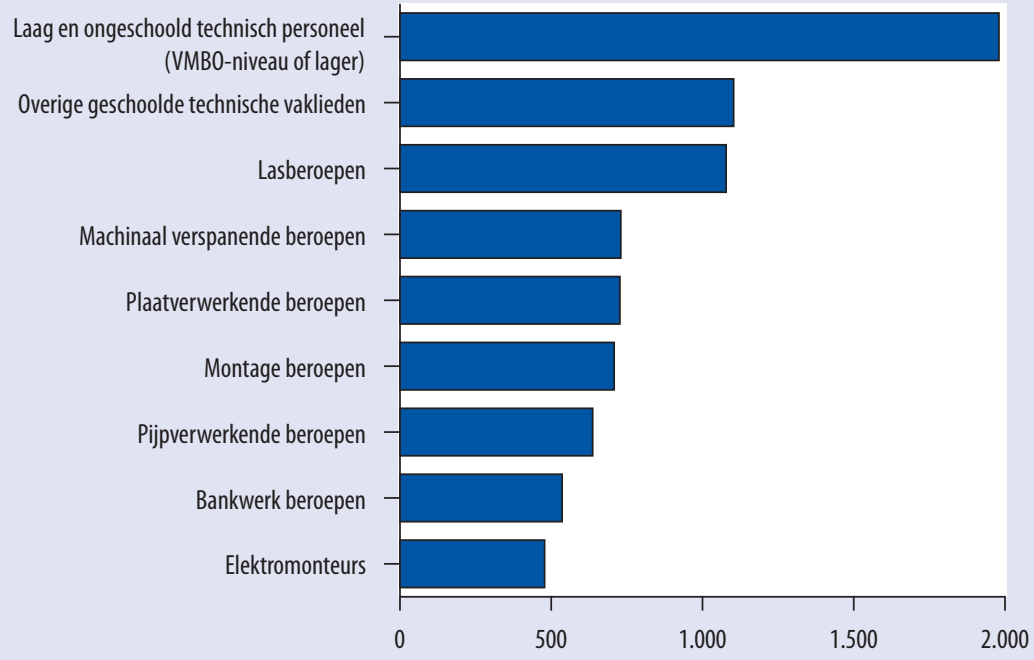

Bron: ROA / Werkgeverspanel Metalektro 2010

Figuur 3.5 geeft een nauwkeuriger beeld van de vacatures die er in 2010 bij de metalektrobedrijven waren voor ondersteunende technici. De meeste van deze vacatures hadden betrekking op een breed scala aan ondersteunende functies op $\mathrm{MBO}+$-niveau.

Figuur 3.5

Aantal openstaande vacatures voor ondersteunende technische functies, 2010

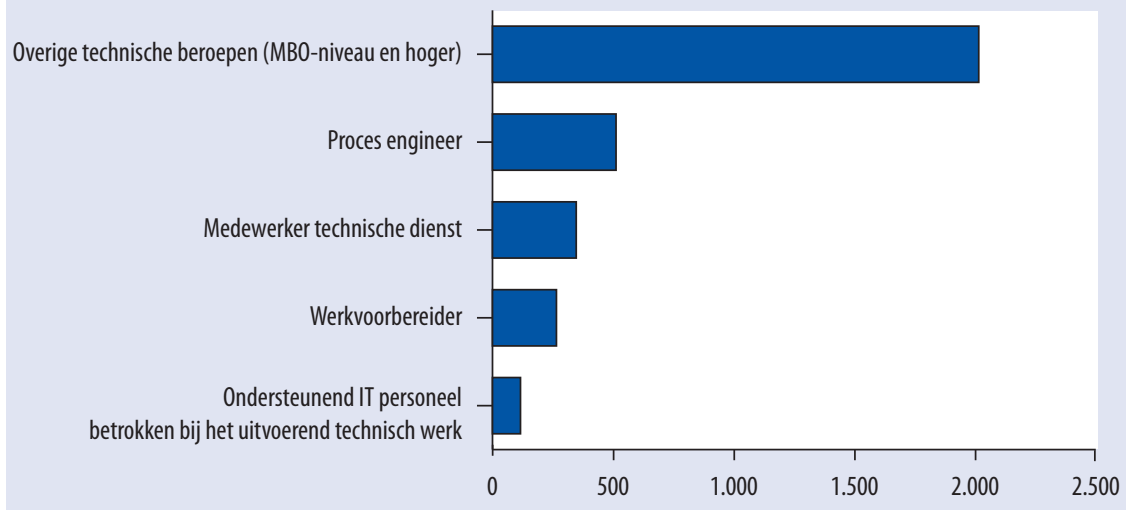

Bron: ROA / Werkgeverspanel Metalektro 2010

Daarnaast waren er ruim 500 vacatures voor proces-engineers en enkele honderden vacatures voor medewerkers technische dienst en werkvoorbereiders. Ook waren er zo'n Ioo vacatures voor ondersteunend IT-personeel. 
Bij het weer aantrekken van het aantal vacatures is het interessant om te achterhalen waarom deze vacatures ontstaan. Enerzijds is het mogelijk dat bedrijven weer vacatures plaatsen omdat men anders het werk niet aan kan (een reactief wervingsbeleid). Anderzijds is het denkbaar dat bedrijven anticiperen op een verwachte toekomstige situatie (een proactief wervingsbeleid). Figuur 3.6 geeft de ontstaansreden(en) van vacatures weer. Bedrijven konden hierbij meerdere antwoordmogelijkheden aangeven.

Figuur 3.6

Bedrijven die proactief of reactief handelen naar de ontstaansreden van vacatures (\% bedrijven), 2010

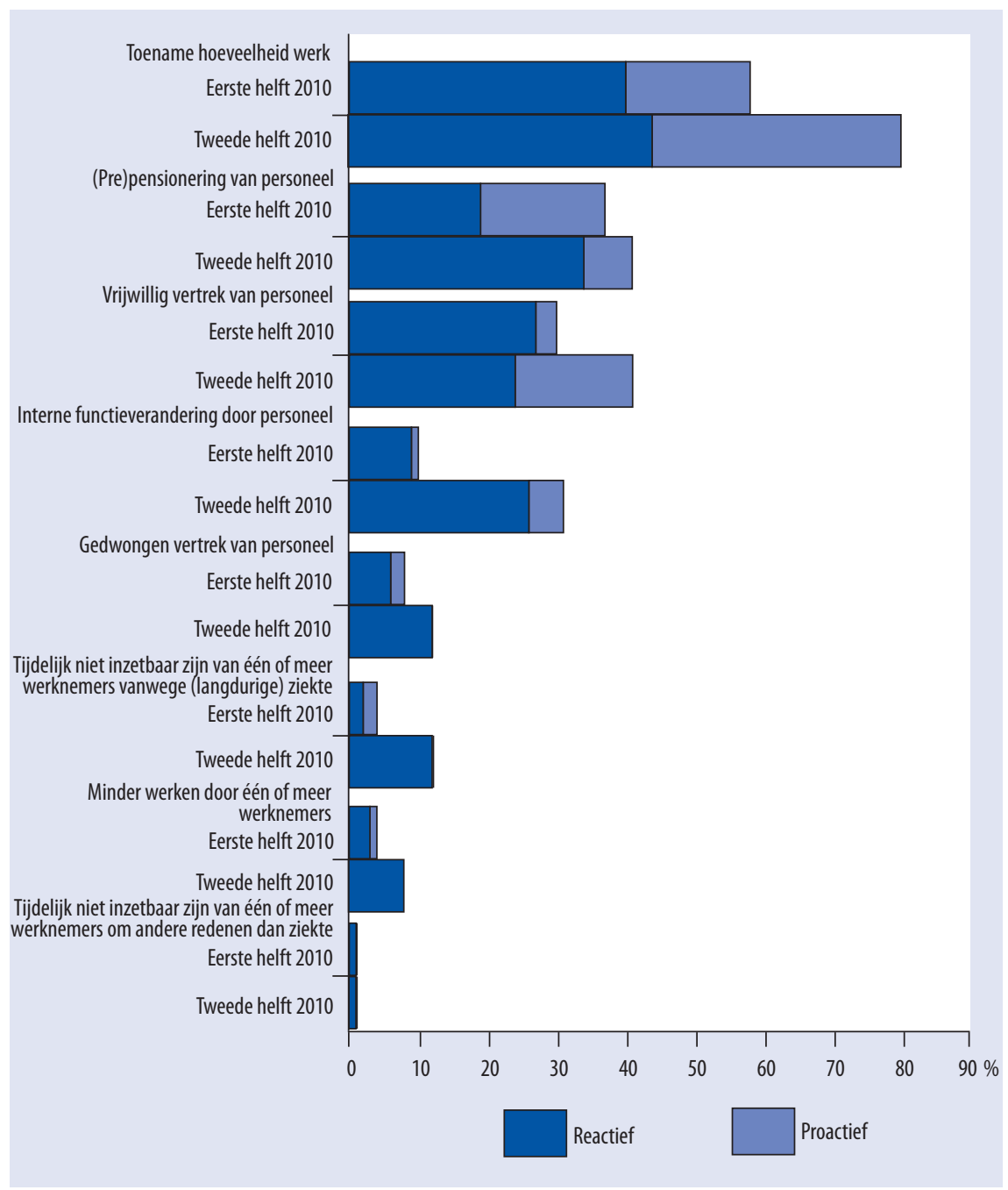

Bron: ROA / Werkgeverspanel Metalektro 2010 
Voor de eerste helft van 20 Io blijkt een kleine 60\% van de bedrijven met openstaande vacatures, een toename van de hoeveelheid werk de reden te zijn voor het ontstaan van deze vacatures. Van deze 60\% geeft tweederde aan dat de vacatures die bij hen open staan reactief zijn. Daarentegen is er bij een derde van deze bedrijven sprake van een proactief wervingsbeleid, waarmee zij willen inspelen op een te verwachten toename van het werk.

Het percentage bedrijven dat aangeeft functies vacant te hebben door een toename van de hoeveelheid werk stijgt in de tweede helft van 2010 tot $80 \%$ van de bedrijven met vacatures. Er is met name sprake van een toename van het aantal bedrijven dat proactief handelt. Dit laat zien dat meer bedrijven optimistisch zijn over de te verwachten ontwikkeling van hun afzet en hierop durven te anticiperen door nu alvast extra personeel aan te trekken.

De figuur laat ook zien dat er daarnaast in nogal wat bedrijven ook vacatures ontstaan doordat er personeel met (pre)pensioen gaat en vrijwillig vertrekt. Daarbij is er meestal sprake van een reactief beleid, al zijn er in de tweede helft van 20 Io meer bedrijven die proactief ook inspelen op het te verwachten vrijwillige verloop van personeel. Verder is de toename van het aantal bedrijven dat aangeeft dat er vacatures zijn ontstaan door interne mobiliteit van medewerkers opvallend te noemen. In de eerste helft van 20 IO noemde slechts IO\% van de bedrijven dit als een reden voor het ontstaan van vacatures, maar in de tweede helft van 2010 was dit gestegen tot $30 \%$ van de bedrijven.

\subsection{Effectieve wervingskanalen}

Om de vacatures voor technici in de Metalektro tijdig in te kunnen vullen, is het van belang om in kaart te brengen welke wervingskanalen hierbij het best kunnen worden ingezet. Figuur 3.7 laat zien welke wervingskanalen volgens de bedrijven zelf het meest effectief zijn om geschikt technisch personeel aan te trekken. Daarbij wordt een onderscheid gemaakt tussen uitvoerend technisch personeel en ondersteunende technici.

Volgens de werkgevers is het uitzendbureau het meest effectieve wervingskanaal om uitvoerende technici en ondersteunende technici aan te trekken. Wel wordt het uitzendbureau bij de uitvoerende technici bijna twee keer zo vaak genoemd als meest effectieve zoekkanaal dan bij de ondersteunende technici. Maar liefst $44 \%$ van de bedrijven noemt het uitzendbureau als de meest effectieve weg om uitvoerende technici aan te trekken, terwijl $23 \%$ van de bedrijven het uitzendbureau het meest effectieve wervingskanaal vindt voor het invullen van vacatures voor ondersteunende technici. Andere wervingskanalen die volgens de bedrijven succesvol zijn bij het aantrekken van uitvoerend technisch personeel zijn het plaatsen van advertenties in regionale dagbladen, het gebruik maken van het netwerk van zittend personeel en het raadplegen van internet. Voor het werven van ondersteunende technici zijn naast de uitzendbureaus, vooral advertenties in regionale dagbladen $(20 \%)$ en het werven via internet ( $14 \%)$ de uitschieters. Dit bete- 
kent dat advertenties in regionale dagbladen en het zoeken op internet twee keer zo vaak het meest effectief genoemd worden bij het werven van ondersteunende technici.

\section{Figuur 3.7}

Meest effectieve wervingskanalen voor het aantrekken van uitvoerend en ondersteunend technisch personeel, 2010 (\% bedrijven)*

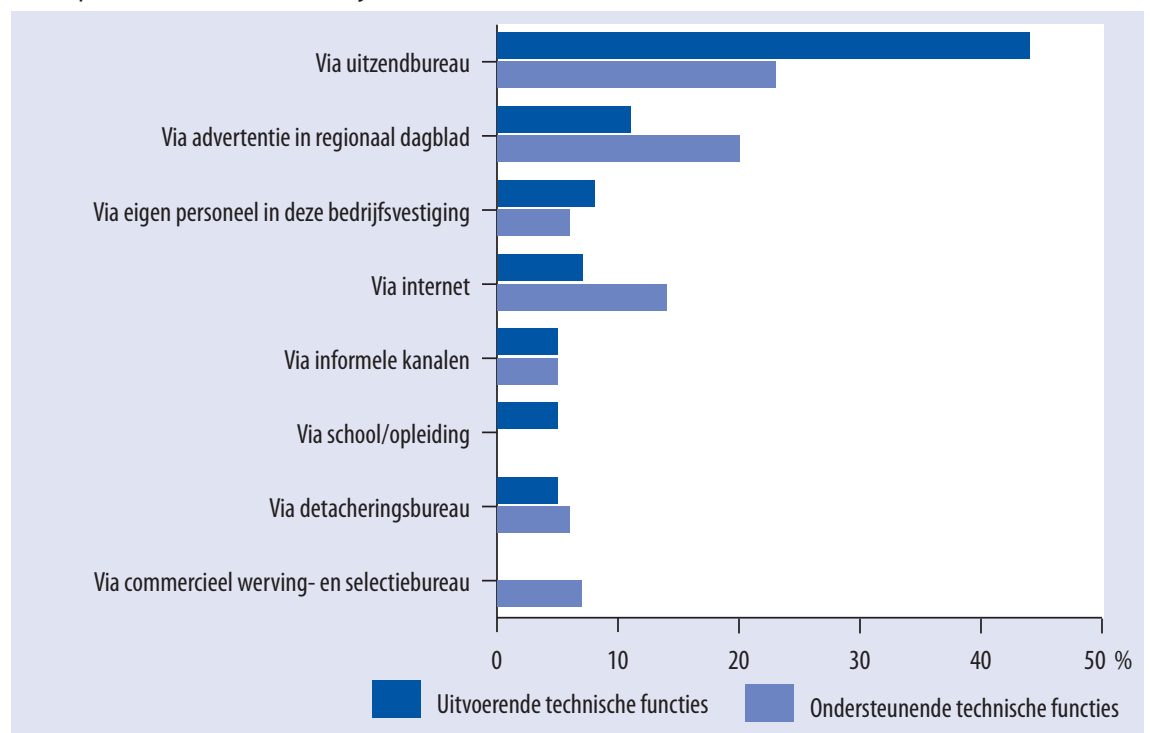

* De wervingskanalen die door minder dan $5 \%$ van de bedrijven zijn genoemd zijn weggelaten in deze figuur.

Bron: ROA / Werkgeverspanel Metalektro 2010

\section{Kijk in het netwerk van de eigen werknemers voor geschikte kandidaten}

Werven via het netwerk van de eigen werknemers heeft als voordeel dat de kans op een goede match tussen de persoonlijkheid van de kandidaten en de cultuur van het team of de organisatie groter is dan bij kandidaten buiten dit netwerk. Deze match is vaak cruciaal voor het garanderen van een goede communicatie binnen het team waarin iemand werkzaam is en tussen teams die moeten samenwerken. Deze communicatie is van groot belang voor het waarborgen van een hoge kwaliteit van het product en het optimaal kunnen inspelen op de wensen van klanten.

Uit figuur 3.8 blijkt dat commerciële werving- en selectiebureaus het meest effectieve wervingsinstrument zijn voor het werven van leidinggevende technici (I7\%), op korte afstand gevolgd door het zoeken via internet (I6\%), het plaatsen van advertenties in regionale dagbladen ( $13 \%$ ) en het inschakelen van uitzendbureaus (IO\%). Technisch opgeleide verkopers worden nog veel vaker via commerciële werving- en selectiebureaus gevonden. Maar liefst $27 \%$ van de bedrijven vindt dat deze bureaus het meest effectief zijn voor het aantrekken van nieuwe mensen in deze technisch-commerciële 
functies. Andere effectieve wervingskanalen voor het vinden van technisch opgeleide verkopers zijn respectievelijk het internet (I4\%) en het informele netwerk (9\%).

\section{Figuur 3.8}

Meest effectieve wervingskanalen voor het aantrekken van leidinggevend technisch personeel en technisch opqeleide verkopers, 2010 (\% bedrijven)*

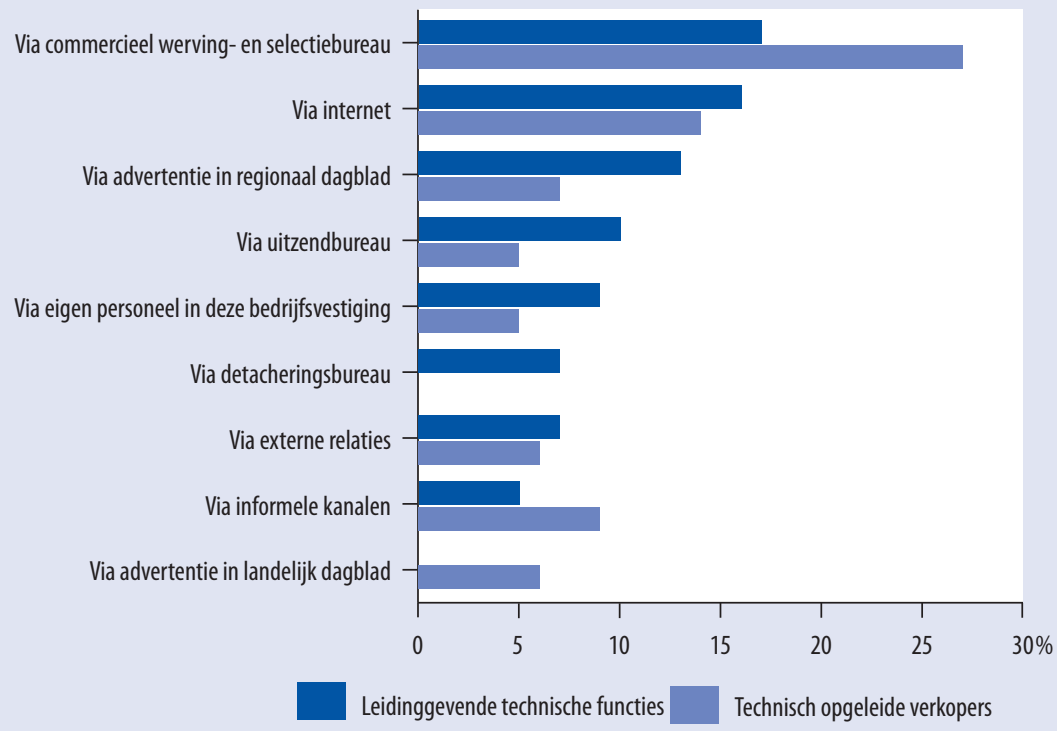

* De wervingskanalen die door minder dan $5 \%$ van de bedrijven zijn genoemd zijn weggelaten in deze figuur.

Bron: ROA / Werkgeverspanel Metalektro 2010

\subsection{Wervingsproblemen en bijbehorende maatregelen}

In het Werkgeverspanel Metalektro wordt ieder jaar ook gevraagd in hoeverre de bedrijven problemen hebben bij het aantrekken van technisch personeel. Figuur 3.9 geeft een overzicht van de ontwikkeling van de ernst van de wervingsproblematiek in de periode 2002-20I0. Uit de figuur blijkt dat het vanaf 2005 voor veel bedrijven moeilijker werd om voldoende geschikt personeel te vinden. In 2007 hadden de metalektrobedrijven de meeste wervingsproblemen. In dat jaar gaf bijna de helft van alle bedrijven aan veel of zelfs erg veel problemen te hebben bij het aantrekken van technisch personeel. In 2009 nam het aantal bedrijven dat met wervingsproblemen kampte af. Toen ondervond slechts $8 \%$ van de bedrijven (zeer) veel problemen bij de werving van technisch personeel. In dat jaar gaf bijna $70 \%$ van de bedrijven aan dat ze geen of weinig wervingsproblemen meer hadden. Dit illustreert dat er tijdens de crisis op de ruime arbeidsmarkt genoeg technisch personeel voor handen was. Dit percentage bleef in 2010 nagenoeg constant. Toch zien we in 2010 wel weer een toename van het percentage bedrijven dat veel wervingsproblemen heeft ( $13 \%)$. 


\section{Figuur 3.9}

Ontwikkeling van wervingsproblemen voor technisch personeel (\% bedrijven), 2002-2010

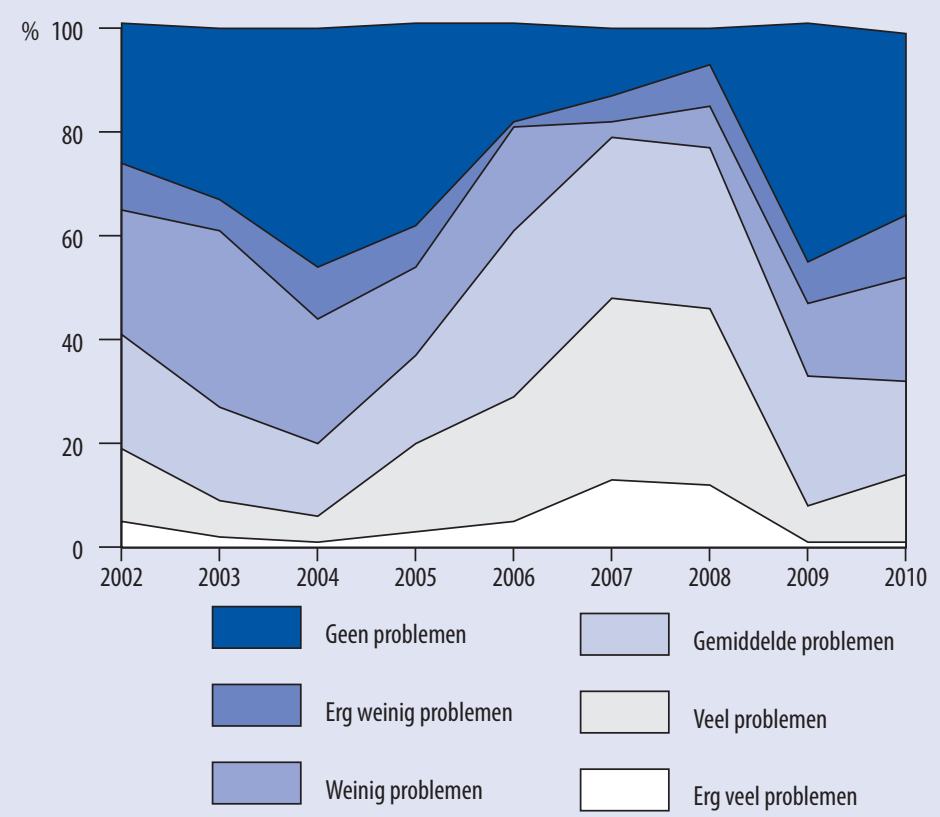

Bron: ROA / Werkgeverspanel Metalektro 2002-2010

\section{Onbekend maakt onbemind: de PR-kracht van BPV-plaatsen, afstudeerprojecten en rondleidingen}

Hetbieden van stages, leerbanen en afstudeerprojecten kan ook worden gezien als een manier om de naamsbekendheid van het bedrijf onder leerlingen en studenten te vergroten. Het geven van rondleidingen aan studieverenigingen van technische universiteiten is een andere manier om aan de weg der publiciteit te timmeren.

Figuur 3.Io laat zien dat de ernst van de wervingsproblematiek sterk afhangt van de functies die het betreft. Bedrijven in de Metalektro hebben de voorbije jaren vooral moeite met het invullen van vacatures voor uitvoerende technische functies. Voordat de crisis eind 2008 toesloeg had zelfs 8 op de io bedrijven problemen bij het werven van nieuwe mensen voor deze functies. In 2010 is dit percentage weliswaar behoorlijk afgenomen, maar dit neemt niet weg dat nog altijd 6 op de Io bedrijven bij deze functies wervingsproblemen ondervindt.

De ontwikkeling van het percentage bedrijven met wervingsproblemen voor ondersteunende technici kent een enigszins vergelijkbaar verloop. Het percentage bedrijven met wervingsproblemen voor ondersteunende technici is echter beduidend lager dan voor uitvoerende technici. De ontwikkeling van de wervingsproblematiek voor de 
- doorgaans hoger opgeleide - leidinggevende technici en technisch opgeleide verkopers kent daarentegen een ander verloop. Al met al ligt de wervingsproblematiek voor leidinggevende technici, ondersteunende technici, alsook technisch opgeleide verkopers in 2010 op min of meer hetzelfde niveau. Circa $20 \%$ van de bedrijven geeft aan moeite te hebben met het vinden van geschikt personeel voor deze drie functiecategorieën.

\section{Figuur 3.10}

Ontwikkeling van wervingsproblemen voor technische functies per functiecategorie (\% bedrijven), 2006-2010

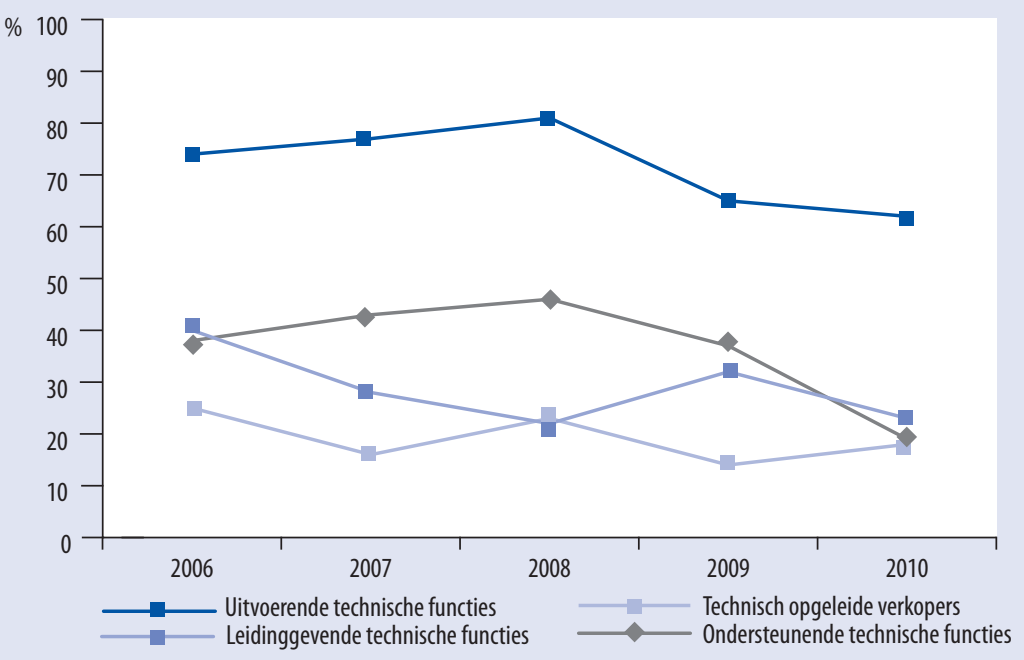

Bron: ROA / Werkgeverspanel Metalektro 2006-2010

De problemen die bedrijven ondervinden bij het werven van technisch personeel, kunnen herleid worden tot enkele belangrijke oorzaken. Figuur 3.II laat zien wat de belangrijkste oorzaken zijn voor de problemen bij het invullen van deze vacatures. In zowel 2009 als 2010 beschikken de sollicitanten volgens 62\% van de bedrijven niet over de vereiste competenties. In 20 Io wordt daarnaast door zo'n $30 \%$ van de bedrijven aangegeven dat hun sollicitanten te weinig werkervaring hebben, of dat er gewoonweg te weinig sollicitanten voorhanden waren. In 2009 waren er nog meer bedrijven die problemen hadden bij het invullen van hun vacatures, omdat de sollicitanten op deze vacatures onvoldoende werkervaring hadden. $43 \%$ van de bedrijven noemde dit in 2009 als oorzaak voor hun wervingsproblemen. Een ander probleem dat zich in 2009 voordeed was dat de sollicitanten te hoge salariseisen op tafel legden (31\%). Dit percentage is in 2010 gehalveerd. Andere veelgenoemde oorzaken waren in 2009 'te weinig aanbod van sollicitanten' en 'te weinig aanbod van arbeidskrachten met interesse in het technisch vakgebied'. 


\section{Figuur 3.11}

Belangrijkste oorzaken van de ondervonden problemen bij het vervullen van vacatures voor technisch personeel (\% bedrijven), 2009-2010

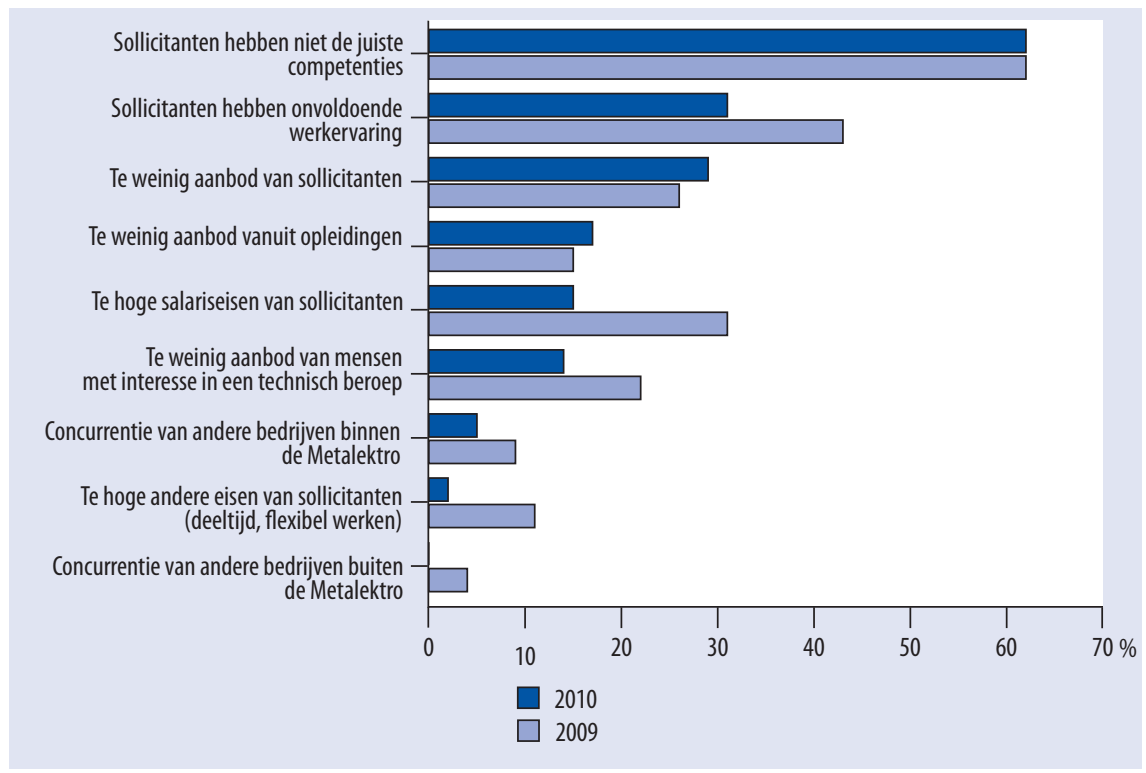

Noot: Bedrijven konden de drie belangrijkste redenen aangeven (zonder rangorde). Bron: ROA / Werkgeverspanel Metalektro 2009-2010

Wanneer bedrijven niet in staat zijn om openstaande vacatures tijdig in te vullen, zal dit in de praktijk meestal direct merkbare gevolgen hebben. Figuur 3.12 geeft een overzicht van deze gevolgen in de jaren 2009 en 20IO. In 2009 leidde het tekort aan technisch personeel bij meer dan de helft van de bedrijven (55\%) tot een toenemende werkdruk. Ook bleef er bij 30\% van de bedrijven werk liggen of werden er deadlines niet gehaald. Daarnaast was er door het niet kunnen invullen van bepaalde vacatures bij verschillende bedrijven sprake van een toename van de wervings- en opleidingskosten, langere levertijden, en $20 \%$ van de bedrijven gaf aan dat er hierdoor minder mogelijkheden waren om innovaties door te voeren dan men zou willen.

\section{Differentiatie in wervingskanalen van belang bij een diverse wervingsvraag}

Een metalektrobedrijf dat veel facetten van het werk zoals R\&D, testen, productie, verkoop en installatie zelf doet, heeft daarvoor een zeer divers personeelsbestand nodig. De medewerkers van dit bedrijf hebben niet alleen inhoudelijk sterk verschillende functies, maar werken ook op verschillende werk- en denkniveaus (MBO versus HBO/ W0). Deze diversiteit is ook terug te zien in de gebruikte wervingskanalen. Wanneer het bedrijf op zoek is naar productiemedewerkers op MBO-niveau, maakt het bijvoorbeeld gebruik van advertenties in huis-aan-huisbladen, regionale kranten en geeft het bedrijf het personeel een wervingspremie als zij een geschikte sollicitant voordragen. Kandidaten voor de functies op HBO+-niveau (R\&D, testen, etc.) worden daarentegen gezocht via de (technische) universiteiten, Monsterboard, gespecialiseerde wervings- en selectiebureaus, Intermediair en landelijke dagbladen. 
Figuur 3.12

Direct merkbare gevolgen van het tekort aan technisch personeel (\% bedrijven), 2009-2010

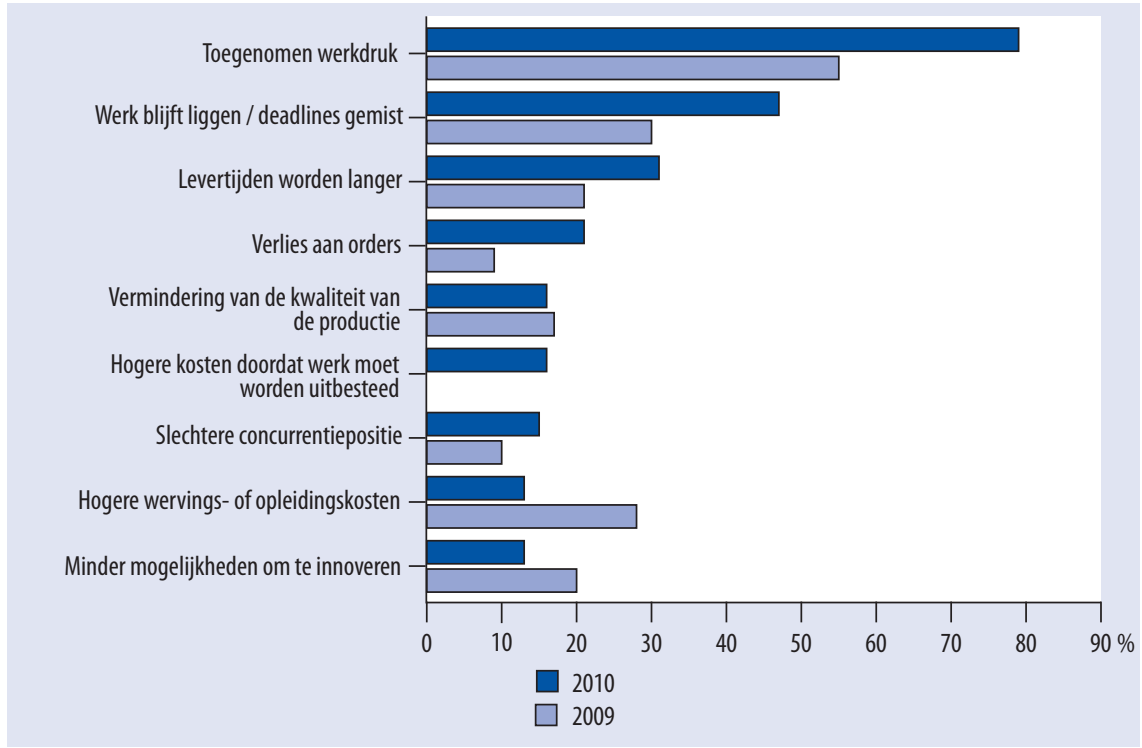

Bron: ROA / Werkgeverspanel Metalektro 2009-2010

Figuur 3.12 laat zien dat het aantal bedrijven dat geconfronteerd wordt met direct merkbare gevolgen van personeelstekorten in 2010 is toegenomen. In maar liefst 8 op de Io bedrijven leidde het tekort aan personeel tot een toenemende werkdruk. Ook het aantal bedrijven waarin door de wervingsproblemen werk bleef liggen of deadlines werden gemist nam sterk toe tot bijna 50\% van alle bedrijven. Bovendien werden in 20 Io in veel meer bedrijven de levertijden langer door de personeelstekorten en was er ook in veel meer bedrijven sprake van een verlies aan orders als gevolg van het tekort aan technisch personeel. De enige oorzaken die in 2010 duidelijk minder werden genoemd dan in 2009 zijn 'hogere wervings- of opleidingskosten' en 'minder mogelijkheden tot innoveren'.

Bedrijven die moeite hebben met het invullen van hun vacatures zullen hier ook op inspelen door hun wervings- en selectiebeleid aan te passen of hun interne organisatie anders in te gaan richten. Figuur 3.13 laat zien hoeveel bedrijven in 2010 op bepaalde punten hun wervings- en selectiebeleid hebben aangepast. Tevens kan uit de figuur afgeleid worden hoe effectief deze aanpassingen volgens de bedrijven zelf waren. Het blijkt dat nagenoeg alle bedrijven (94\%) die in 20 Io te kampen hadden met moeilijk vervulbare vacatures, uitzendbureaus, commerciële werving- en selectiebureaus of detacheringsbureaus hebben ingeschakeld. Meer dan de helft van de metalektrobedrijven ( $54 \%$ ) vindt dit een effectief middel om technisch personeel te werven, terwijl I2\% van de bedrijven dit zelfs een zeer effectief middel vindt om aan personeel te komen. Echter, ruim een kwart van de bedrijven ervaart het inschakelen 
van dergelijke bureaus als weinig effectief. Andere veel genoemde aanpassingen in het wervings- en selectiebeleid zijn het aantrekken van mensen met minder ervaring, het actiever benaderen van scholieren en het bieden van goede loopbaanperspectieven. Ook stelt 50\% van de bedrijven een wervingsbonus in het vooruitzicht aan zittend personeel dat er in slaagt om via hun eigen netwerk nieuw personeel aan te trekken. Veel bedrijven geven echter aan dat dit instrument in de praktijk nauwelijks effect heeft. Werknemers dragen soms wel mogelijke kandidaten voor, maar deze blijken in de praktijk vaak toch onvoldoende geschikt om in dienst genomen te worden. Andere maatregelen die volgens de metalektrobedrijven weinig succesvol zijn, zijn het actiever benaderen van scholieren en het inschakelen van het UWV Werkbedrijf. Dit laatste wervingskanaal is waarschijnlijk minder effectief doordat mensen met minder goede arbeidsmarktperspectieven (bijvoorbeeld lageropgeleiden en ouderen) vaak via deze weg werk proberen te vinden.

\section{Figuur 3.13}

Aanpassingen in het wervings- en selectiebeleid vanwege moeilijk vervulbare vacatures voor technisch personeel en de effectiviteit van deze aanpassingen (\% bedrijven), 2010

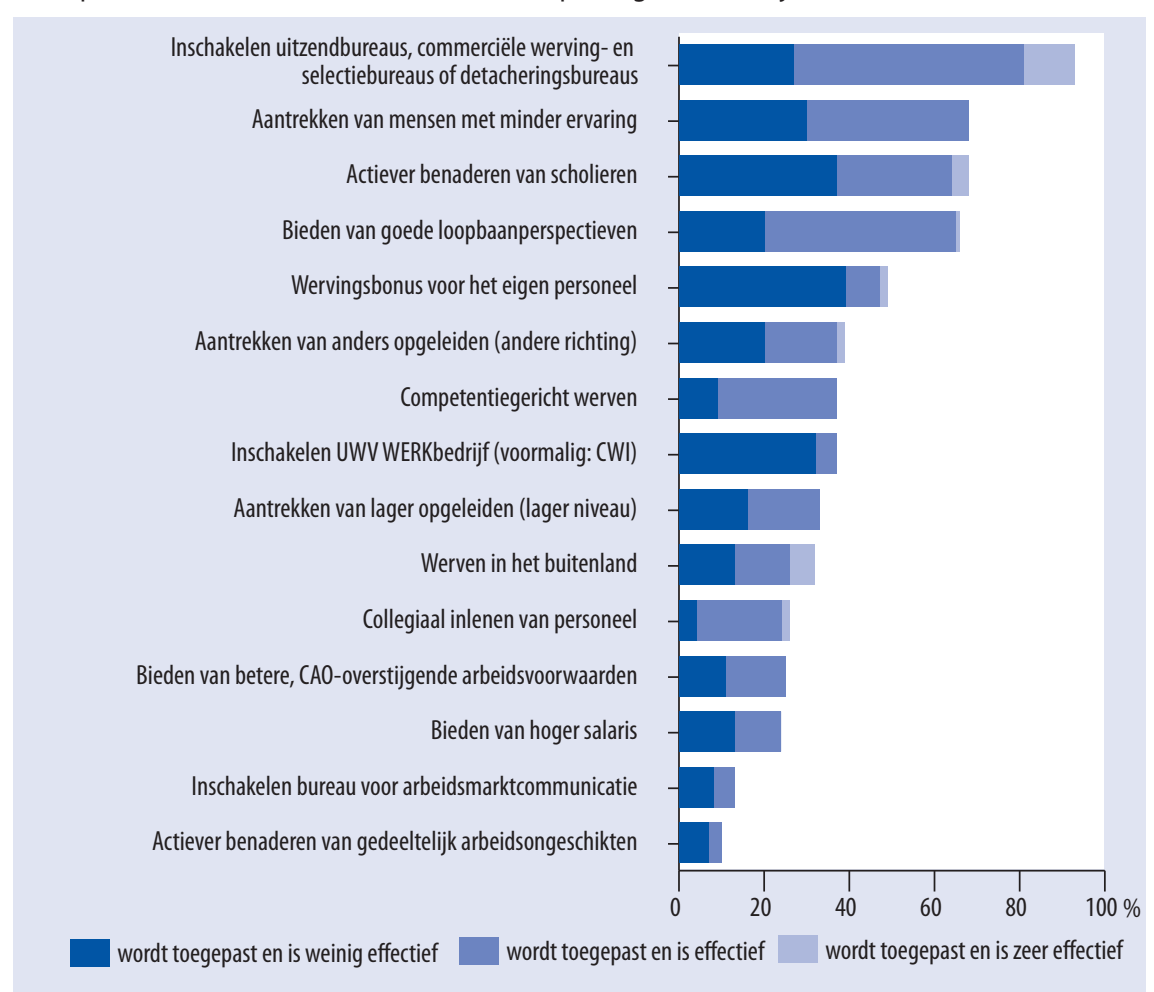

Bron: ROA / Werkgeverspanel Metalektro 2010 
Het bieden van goede loopbaanperspectieven blijkt een veel beter middel om de wervingsproblemen voor technisch personeel te verminderen. Bijna de helft van de bedrijven noemt dit een probaat middel. Tot slot is het opvallend dat bedrijven in 20 Io vrijwel geen enkele maatregel op het gebied van werving en selectie zeer effectief vinden.

\section{Figuur 3.14}

Interne aanpassingen vanwege moeilijk vervulbare vacatures voor technisch personeel en de effectiviteit van deze aanpassingen, 2010 (\% bedrijven)

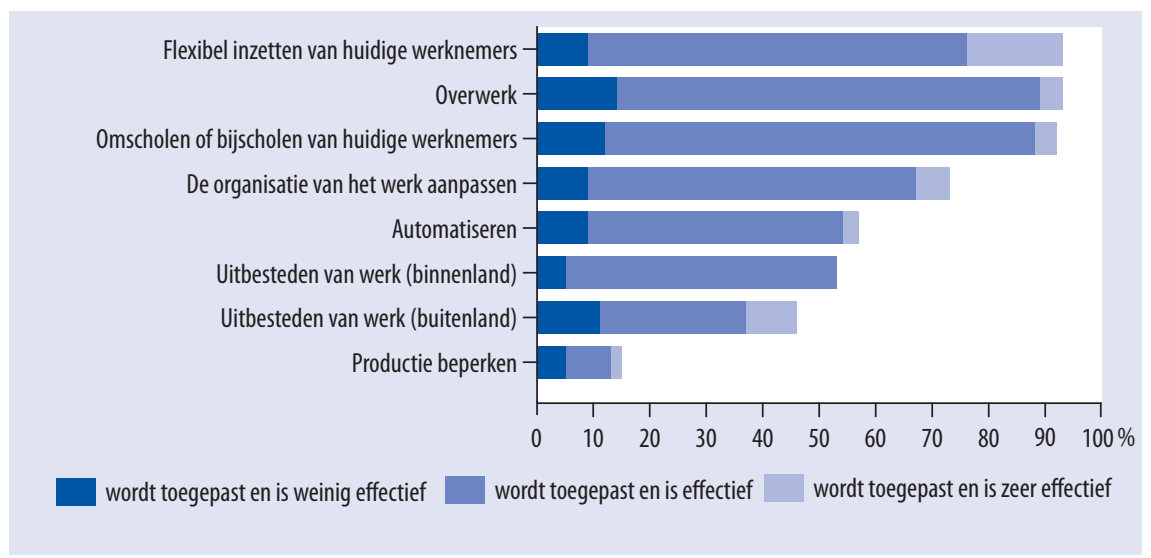

Bron: ROA / Werkgeverspanel Metalektro 2010

Bedrijven die kampen met moeilijk in te vullen vacatures kunnen er ook voor kiezen om hun interne organisatie anders in te gaan richten. Figuur 3.I4 laat zien welke interne aanpassingen er in de metalektrobedrijven zoal worden gedaan en, minstens zo belangrijk, hoe effectief deze aanpassingen in de praktijk zijn. Ruim 9 op de Io bedrijven hebben er in 2010 voor gekozen om het tekort aan technisch personeel op te vangen door hun werknemers flexibel in te zetten, over te laten werken, of om- en bij te scholen. Zeker in economisch gezien onzekere tijden waarin veel bedrijven nog niet durven over te gaan tot het in vaste dienst nemen van nieuw personeel, zijn dit vaak toegepaste middelen om een personeelstekort tijdelijk op te kunnen vangen. Volgens de meeste bedrijven zijn deze aanpassingen ook effectief. Afgezien van het om- en bijscholen van zittend personeel gaat het hier waarschijnlijk meestal om korte-termijnoplossingen. Het blijft dan ook de vraag of deze maatregelen ook op de langere termijn effectief zullen zijn.

Driekwart van de bedrijven geeft ook aan dat ze in 20 Io de organisatie van het werk aangepast hebben. Het flexibel inzetten van het personeel wordt het meest als een zeer effectieve interne aanpassing genoemd, gevolgd door het uitbesteden van werk naar het buitenland en het aanpassen van de organisatie van het werk. Opmerkelijk is echter wel dat er, hoewel de economie in 20 Io pas net weer uit het dal omhoog kruipt, toch al weer I $4 \%$ van de bedrijven genoodzaakt is om de productie te beperken, omdat er te weinig geschikt personeel voor handen is. 



\section{Competentiemanagement}

Competentiemanagement begint met het vaststellen van de bij het personeel aanwezige competenties. De meerderheid van de metalektrobedrijven kan dit doen door te putten uit functionerings-of beoordelingsgesprekken. Ze verwachten dat hun personeel in de toekomst meer zal moeten kunnen bogen op de PROFI-competenties (in het bijzonder probleemoplossend vermogen en flexibiliteit) gecombineerd met kennis delen en samenwerken. Een kwart van de bedrijven zit in de spagaat van de gelijktijdige behoefte aan technisch specialisten én technische allrounders. Vier van de vijf recent ingestroomde schoolverlaters met een $M B O$ - of HBO-diploma op zak vindt dat de functie redelijk tot goed aansluit op de opleiding. MBO'ers hebben vooral kennis en probleemoplossend vermogen nodig, terwijl schrijven, spreken en vreemde talen minder van hen gevraagd worden. HBO'ers kunnen naar eigen zeggen prima voldoen aan de vraag naar hun competenties rond het leren van nieuwe dingen, samenwerken, ICT en discussiëren. Qua kennis, besluitvaardigheid, werken binnen grenzen en duidelijk communiceren is er echter ruimte voor verbetering. Technici in vaste dienst nemen veel vaker deel aan trainingen e.d. dan de 'tijdelijken'. De scholingskosten zijn in absolute termen stabiel, maar als percentage van de loonsom weer wat dalend. Scholing is nog steeds hoofdzakelijk gericht op vakinhoudelijke kennis, hoewel de aandacht voor enkele gedragsmatige competenties enigszins toeneemt. Vooral (verloren werk-)tijd en geld weerhouden bedrijven ervan meer technici te laten scholen. $56 \%$ van de bedrijven heeft weer interne mobiliteit. Deze mobiliteit is iets vaker horizontaal dan verticaal. Onvoldoende hogere functies en kennis bij het personeel beperken de interne mobiliteit. Vier van de vijf bedrijven faciliteert de ontwikkeling van haar personeel overigens uit een bedrijfsopleidingsbudget, maar het persoonlijke opleidingsbudget is aan een opmars bezig: $14 \%$ van de metalektrobedrijven biedt een dergelijk budget aan.

\subsection{Vaststellen huidig en gewenst competentieniveau}

Het actief managen van de competenties van de werknemers in de Metalektro is geen luxe maar bittere noodzaak. Deze noodzaak komt om te beginnen voort uit de vergrijzing in combinatie met de ontgroening: oudere werknemers zullen in de komende jaren met pensioen gaan (zie hoofdstuk 6) en er zijn onvoldoende jongeren om deze vrijgekomen plaatsen op te vangen, zodat personeelstekorten en dus ook competentietekorten (wederom) op de loer liggen. Daarnaast zal de verwachte verbetering van 
de conjunctuur (zie hoofdstuk I) deze personeelstekorten in de komende jaren verder aanwakkeren. Bovendien is de Metalektro een zeer innovatieve bedrijfstak (zie hoofdstuk I) waarbij technologische en sociale innovaties hand in hand gaan (zie hoofdstuk 5). Ook deze innovaties hebben hun weerslag op wat er nu en in de toekomst van het personeel gevraagd zal worden. Kort samengevat: om als Metalektro optimaal te kunnen presteren, is het van groot belang om de kennis en kunde van al het aanwezige personeel continu te ontwikkelen.

Een actief competentiemanagement begint met het doen van een nulmeting: wat hebben de werknemers op dit moment aan kennis en vaardigheden in huis? Vervolgens wordt bepaald welke kennis en vaardigheden het personeel zou moeten bezitten en op welke termijn. Op beide zaken wordt in deze paragraaf ingegaan. Daarnaast wordt in paragraaf 4.2 geschetst met welke competenties de recente lichtingen schoolverlaters de Metalektro zijn ingestroomd. Wanneer duidelijk is welke kennis en vaardigheden in huis zijn en welke nodig zijn, kunnen bedrijven zich richten op het ontwikkelen van de benodigde kennis en vaardigheden die nu nog bij hun personeel ontbreken. In dit hoofdstuk komen twee ontwikkelmethoden aan bod: scholing in paragraaf 4.3 en interne mobiliteit in paragraaf 4.4. Tot slot wordt in paragraaf 4.5 een overzicht gegeven van de gebruikte HRM-instrumenten in de Metalektro.

\section{Nulmeting}

Voor het uitvoeren van de eerdergenoemde nulmeting hebben bedrijven een aantal instrumenten ter beschikking, te weten het functioneringsgesprek, het beoordelingsgesprek, de competentie- of vaardighedenmatrix en EVC (Erkenning van Verworven Competenties). Vorig jaar werden in driekwart van de bedrijven functioneringsgesprekken gevoerd en in twee derde vonden beoordelingsgesprekken plaats. Beide percentages zijn iets lager dan in voorgaande jaren. Eén op de vijf bedrijven maakt gebruik van EVC en $31 \%$ gebruikt de competentie- of vaardighedenmatrix. In het overgrote deel van de bedrijven wordt minimaal één van deze vier instrumenten gebruikt, echter $17 \%$ gebruikt geen van deze instrumenten.

\section{Verwachte functieveranderingen}

Om te weten welke competenties het personeel (verder) dient te ontwikkelen, moeten bedrijven een inschatting maken of en zo ja, op welke manier de functies van hun personeel in de komende jaren zullen veranderen. In figuur 4.I is te zien welke functieveranderingen de metalektrobedrijven in de komende vijf jaar verwachten. Bijna $40 \%$ van de bedrijven voorziet een status quo tussen nu en 20I5: zij verwachten geen veranderingen in de functies van hun technisch personeel. Daarentegen zal ongeveer de helft meer verantwoordelijkheid geven aan haar technici lager in de organisatie. Verder verwacht iets meer dan de helft van de bedrijven dat technische functies meer allround zullen worden. $43 \%$ denkt dat technische functies juist specialistischer worden. $\mathrm{Nu}$ is het opmerkelijke dat bijna een kwart van de bedrijven zegt dat de 
technische functies in hun bedrijf meer allround zullen worden én dat tegelijkertijd de technische functies in hun bedrijf specialistischer zullen worden. Deze op het eerste gezicht opmerkelijke combinatie werd in de vorige Monitor ook waargenomen. Een voor de hand liggende verklaring is dat deze combinatie in grotere bedrijven vaker voor zal komen dan in kleinere bedrijven, omdat grotere bedrijven een grotere diversiteit aan functies zullen hebben. In dat geval zijn verschillende ontwikkelingen voor verschillende functies in hetzelfde bedrijf denkbaar. De data ondersteunen deze verklaring echter niet: de combinatie komt vrijwel even vaak voor onder kleine, middelgrote en grote bedrijven.

\section{Figuur 4.1}

Verwachte veranderingen in de technische functies in 2011 en 2012-2015 (\% bedrijven)

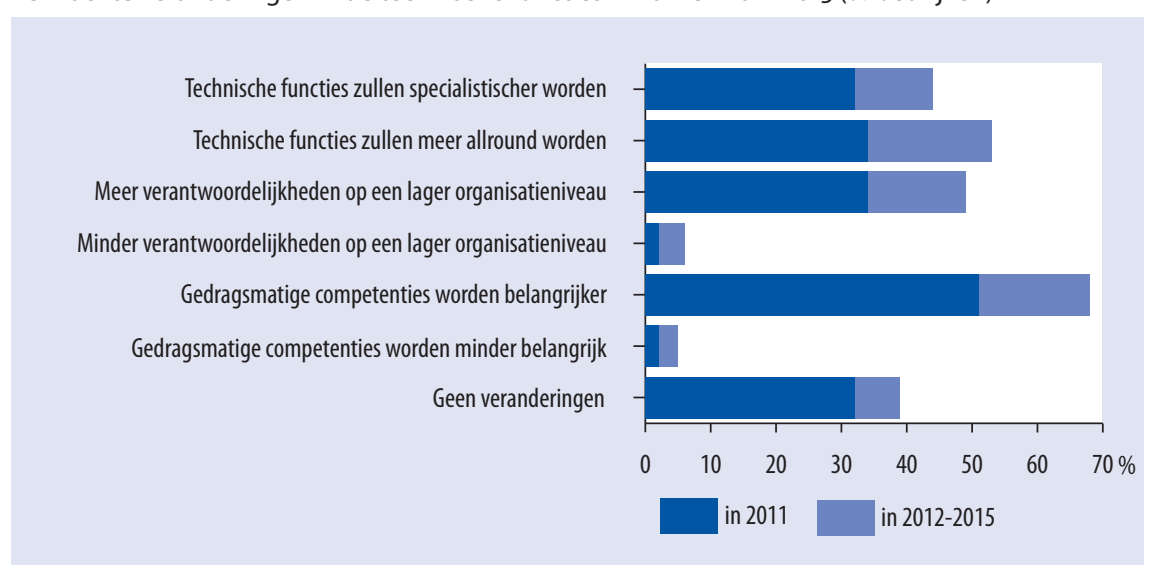

Bron: ROA / Werkgeverspanel Metalektro 2010

De meest genoemde verandering in de technische functies is echter het grotere belang van gedragsmatige competenties: ruim $60 \%$ van de bedrijven verwacht dat deze in de komende vijf jaar belangrijker zullen worden. Maar om welke gedragsmatige competenties gaat het dan? Deze vraag is gesteld aan de bedrijven die hebben aangegeven dat gedragsmatige competenties belangrijker worden. Uit hun antwoorden blijkt dat het vaak om een combinatie van meerdere competenties gaat, waarbij de PROFI'-competenties een belangrijke rol spelen. $72 \%$ noemt het probleemoplossend vermogen en $71 \%$ flexibiliteit. Dit laatste houdt in dat werknemers bereid zijn om verschillende werkzaamheden te doen. $57 \%$ zal meer behoefte hebben aan technici die initiatief durven nemen en eenzelfde percentage heeft technici nodig die kunnen omgaan met technologische en organisatorische veranderingen. Iets minder dan de helft vindt het van belang dat het technisch personeel goed met klanten kan omgaan. Bovenop deze PROFI-competenties verwacht ongeveer 60\% van de bedrijven dat hun technici in staat moeten zijn om kennis te delen en samen te werken. Aan de technici worden dus nogal wat eisen gesteld in de komende jaren. Wanneer uit de eerderge-

6. De PROFI-competenties zijn probleemoplossend vermogen, relaties met klanten, omgaan met veranderingen, flexibiliteit en initiatief nemen. 
noemde nulmeting blijkt dat de benodigde competenties ontbreken, is de noodzaak tot ontwikkeling daar. Uit figuur 4.I blijkt ook dat waarschijnlijk enige haast geboden is, omdat de meeste bedrijven die veranderingen verwachten, vermoeden dat deze zich al in $20 I I$ zullen voltrekken.

\section{Latente leerbehoefte zichtbaar maken: lezen, luisteren en vragen stellen}

Over de latente leerbehoeften van werknemers kan veel geleerd worden door de verslagen van de functioneringsgesprekken goed te bestuderen. Daarnaast is regelmatig overleg met leidinggevenden over het functioneren van werknemers een belangrijke informatiebron bij het vaststellen van hun leerbehoefte.

\subsection{Competentieniveau van de schoolverlaters}

De uitkomsten van de in de vorige paragraaf beschreven nulmeting in combinatie met de verwachte functieveranderingen, geven een beeld van de manier waarop de competenties van de werknemers zich in de komende jaren dienen te ontwikkelen. In de nu volgende paragraaf wordt ingegaan op de competenties van de schoolverlaters die onlangs in de Metalektro aan de slag zijn gegaan. Een overzicht van de competenties van deze jonge werknemers kan laten zien welke competenties nog ontbreken, zodat bedrijven hier hun ontwikkelactiviteiten op kunnen richten. De gegevens in deze paragraaf zijn afkomstig uit de BVE-monitor en de HBO-monitor van het ROA. In deze monitoren worden afgestudeerden anderhalf jaar na het afronden van hun beroepsopleiding geënquêteerd. Voor deze paragraaf zijn de afgestudeerden van de studies Elektrotechniek en Werktuigbouwkunde op MBO- en HBO-niveau geselecteerd die werkzaam zijn in de Metalektro. De gebruikte cijfers zijn afkomstig van de enquêtes uit 2009 en 2010 , die betrekking hebben op de afgestudeerden Elektrotechniek en Werktuigbouwkunde die in de schooljaren 2007/2008 en 2008/2009 hun diploma behaalden. Daarbij gaat het in totaal om 2.400 MBO-afgestudeerden en I.000 HBO-afgestudeerden.

\footnotetext{
Werknemers leren dat begeleiden leuk is

$0 \mathrm{~m}$ de vergrijzing op te vangen en anticiperend op een arbeidsmarktkrapte is een metalektrobedrijf opnieuw begonnen met het bieden van stages voor MBO BOL 1-4 leerlingen in de productie. De productiewerknemers hebben veel plezier in het begeleiden van deze leerlingen. Het bedrijf zou ook graag stages en afstudeerprojecten aanbieden op HBO(+)-niveau 0.a. binnen de R\&D-afdeling, maar helaas zijn de R\&D'ers niet zo enthousiast. De tijdsinvestering in combinatie met de werkdruk overschaduwt bij hen het zicht op de lusten van het begeleiden van studenten. Door de BOL-leerlingen aan hun competentie tekenen te laten werken op de R\&D-afdeling, laat het bedrijf deze afdeling geleidelijk aan ervaren dat stagiaires ook wat op kunnen leveren. Zij zijn bijvoorbeeld bekend met 3D tekenen, terwijl die vaardigheid bij sommige R\&D'ers ontbreekt.
} 


\section{Aansluiting opleiding - huidige functie}

De meeste MBO'ers en HBO'ers die werkzaam zijn in de Metalektro vinden dat hun huidige functie redelijk tot goed aansluit bij hun gevolgde opleiding. $63 \%$ van de $\mathrm{MBO}-$ afgestudeerden vindt de aansluiting redelijk en $24 \%$ vindt deze zelfs goed. Bij de $\mathrm{HBO}$-afgestudeerden vindt $56 \%$ de aansluiting redelijk en geeft $29 \%$ het oordeel 'goed'. Bovendien zegt slechts een paar procent van de MBO'ers en HBO'ers dat hun capaciteiten tekortschieten voor het werk dat ze moeten doen. Deze relatief goede aansluiting hangt waarschijnlijk samen met het gevoerde wervings- en selectiebeleid van de bedrijven. Immers, $67 \%$ van de $\mathrm{MBO}$ 'ers en zelfs $89 \%$ van de HBO'ers heeft een baan waarvoor dat opleidingsniveau nodig is. Ook vroegen werkgevers vaak om de door de afgestudeerde gevolgde opleidingsrichting of een daaraan verwante richting. Dit was bij 44\% van de MBO'ers en bij 63\% van de HBO'ers het geval. Daarnaast vroeg de werkgever bij $40 \%$ van de $\mathrm{MBO}$ 'ers en $27 \%$ van de $\mathrm{HBO}$ 'ers uitsluitend om de door hen gevolgde opleidingsrichting.

\section{Het aanbieden van beroepspraktijkvorming-plaatsen: wel willen, maar moeilijk kunnen \\ Bedrijven die stages of leerbanen aan MBO-leerlingen en afstudeerprojecten aan $\mathrm{HBO}(+)$ studenten willen aanbieden, lopen daarbij tegen bepaalde hindernissen op. Zo kunnen de eisen die gesteld worden aan de bedrijfsbegeleider een struikelblok vormen, maar ook de verplichting om BBL-leerlingen een contract aan te moeten bieden na voltooiing van hun opleiding.}

\section{Competenties MBO'ers}

De competenties van de $\mathrm{MBO}$ - en de $\mathrm{HBO}$-afgestudeerden Elektrotechniek en Werktuigbouwkunde die werkzaam zijn in de Metalektro, worden hierna apart besproken, omdat afgestudeerden in de BVE-Monitor op een andere manier en niet over precies dezelfde competenties worden bevraagd als in de HBO-Monitor. $\mathrm{Om}$ te beginnen wordt in figuur 4.2 een beeld gegeven van de competenties die $\mathrm{MBO}$-afgestudeerden belangrijk of zeer belangrijk vinden om goed te kunnen functioneren in hun huidige functie. In figuur 4.3 wordt ingegaan op de competenties van de $\mathrm{HBO}$-afgestudeerden.

De MBO'ers zijn van mening dat een aantal van de in paragraaf 4.I genoemde PROFI-competenties ook nu al belangrijk zijn voor het goed uitoefenen van hun functie. Zo noemt ruim $80 \%$ problemen oplossen, aanpassingsvermogen ${ }^{7}$ en initiatief/creativiteit als belangrijke tot zeer belangrijke competenties. Ook samenwerken wordt door $8 \mathrm{I} \%$ als (zeer) belangrijk gezien. Daarnaast vindt minimaal vier van de vijf MBO-afgestudeerden zaken als vakkennis en deze in de praktijk kunnen toepassen,

7. Vergelijkbaar met de PROFI-competentie omgaan met veranderingen. 
zelfstandigheid, nauwkeurigheid en zorgvuldigheid van essentieel belang om hun functie naar behoren uit te kunnen voeren.

Figuur 4.2

Percentage MBO-afgestudeerden werkzaam in de Metalektro dat de volgende competenties (zeer) belangrijk vindt voor hun huidige functie (antwoordopties 4 en 5 op een 5 -puntsschaal)

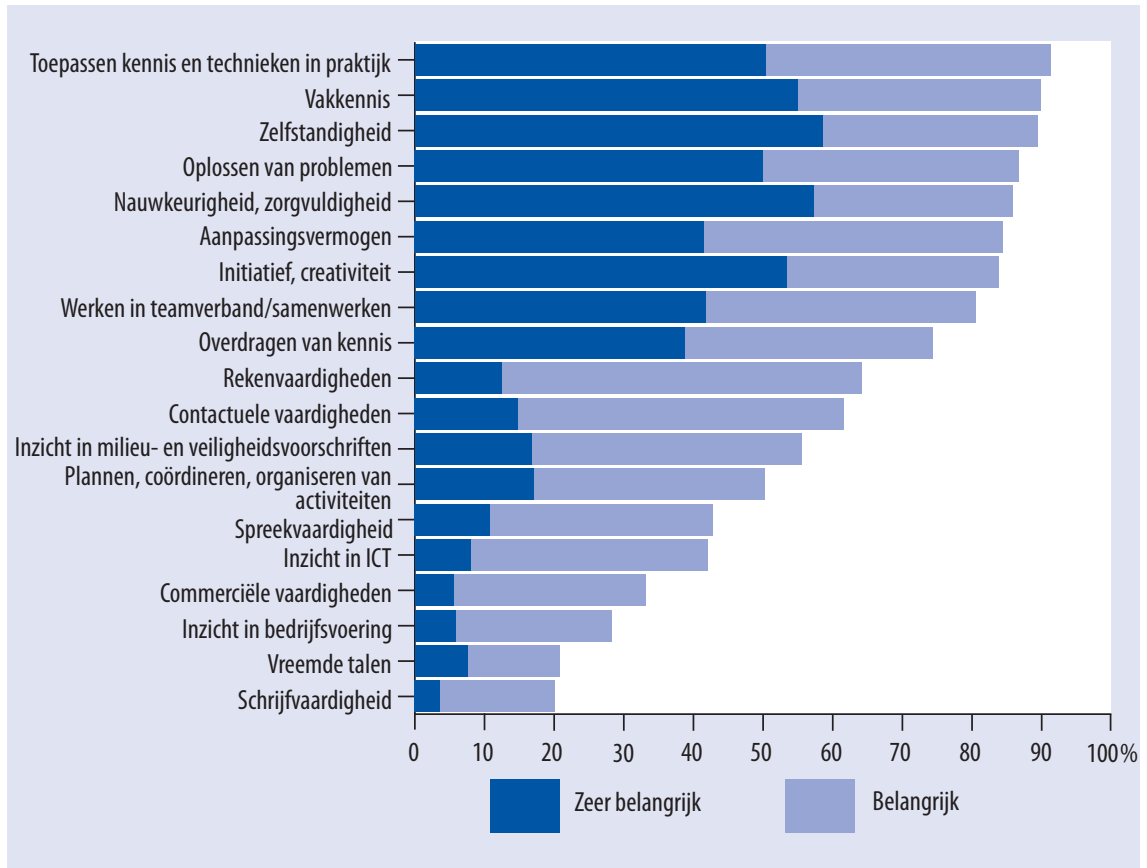

Bron: BVE-Monitor 2009 en 2010, SIS / ROA

Aan de 'onderkant' van figuur 4.2 is te zien dat het gros van de MBO-afgestudeerden competenties als spreek- en schrijfvaardigheid, vreemde talen, commerciële vaardigheden en inzicht in ICT of de bedrijfsvoering niet van belang vindt. Dit kan er op duiden dat deze starters beroepsmatig weinig externe (internationale) contacten hebben, noch in de verkoop/marketing, ICT of het management actief zijn. Gezien hun opleidingsachtergrond en hun nog korte loopbaan is dit overigens niet verwonderlijk.

\section{Competenties HBO'ers}

In de $\mathrm{HBO}$-monitor wordt $\mathrm{HBO}$-afstudeerders per competentie gevraagd welk niveau voor hun functie vereist is en welk niveau zij zelf bezitten. Door de scores op beide vragen per competentie met elkaar te vergelijken, kan worden bepaald of de HBO'ers wat betreft deze competentie op niveau zitten of dat hun eigen niveau te laag is in vergelijking tot het niveau dat voor hun huidige functie vereist is. Het resultaat van deze vergelijking is te zien in figuur 4.3. Deze figuur maakt duidelijk dat, 
door de bank genomen, bij elke competentie minimaal twee derde van de HBO'ers het vereiste competentieniveau bezit. Als het gaat om het leren van nieuwe dingen, samenwerken en ICT-gebruik, geeft zelfs meer dan $80 \%$ van de HBO'ers aan dit in voldoende mate te beheersen. Hetzelfde geldt voor competenties rondom discussie en standpunten: $80 \%$ of meer van de HBO'ers vindt zichzelf voldoende bedreven in het begrip tonen voor andermans standpunten, opkomen voor het eigen standpunt en het ter discussie stellen van zowel eigen als andermans ideeën. Ook de bereidheid om de kop boven het maaiveld uit te steken en het vermogen om logisch te redeneren, zijn volgens vier op de vijf $\mathrm{HBO}$-afgestudeerden in voldoende mate bij hen aanwezig.

\section{Figuur 4.3}

Inschatting van het eigen ten opzichte van het vereiste competentieniveau door HBO-afgestudeerden werkzaam in de Metalektro ${ }^{8}$

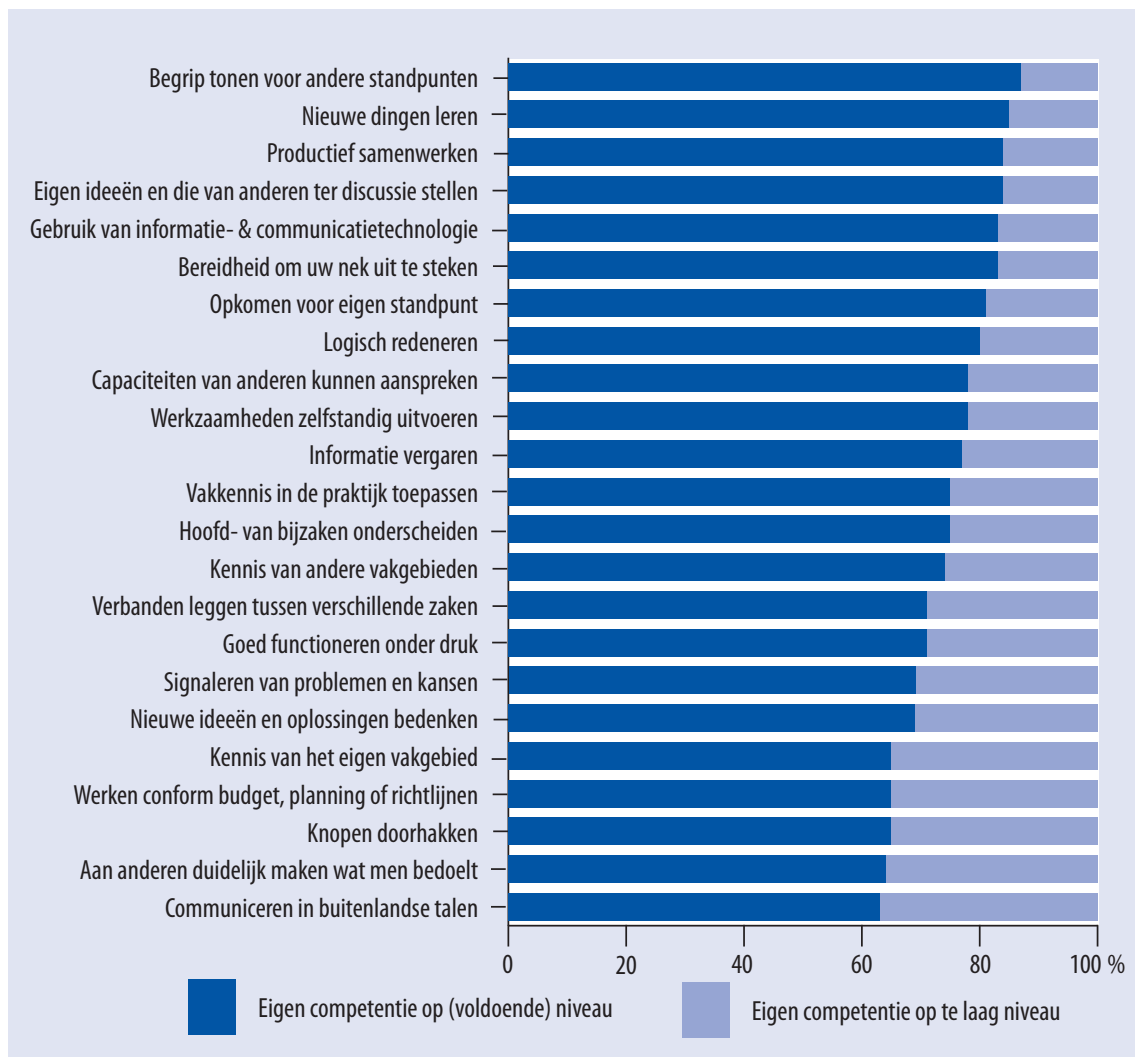

Bron: HBO-Monitor 2009 en 2010, SIS / ROA

8. De HBO-afgestudeerden hebben per competentie twee vragen beantwoord. De eerste vraag betreft het vereiste niveau in hun huidige functie en de tweede hun eigen niveau. Beide vragen worden beantwoord op een schaal die loopt van I (matig) tot en met 5 (uitmuntend). Vervolgens worden de scores van elkaar afgetrokken (score 'vereist niveau' minus 'eigen niveau'). Tot slot worden de HBO'ers met de waardes o $t / m+4$ samengevoegd tot de groep 'Eigen competentie op (voldoende) niveau' en degenen met de waardes $-4 \mathrm{t} / \mathrm{m}$-I vormen de groep 'Eigen competentie op te laag niveau'. 
Waar schort het bij een deel van de HBO'ers dan nog aan? In de onderste regionen van figuur 4.3 is te zien dat communiceren (in een buitenlandse taal), besluitvaardigheid (knopen doorhakken) en werken binnen bepaalde grenzen (bijvoorbeeld van een budget, een planning of richtlijnen) bij een derde als onvoldoende wordt ingeschat. Ook vindt men zich (relatief) nog niet zo goed in het signaleren van problemen en kansen en het komen met nieuwe ideeën en oplossingen. Dit zal zeker te maken hebben met een ander 'gebrek', namelijk de kennis van het eigen vakgebied: $35 \%$ van de HBO'ers vindt dat namelijk te laag.

Uit figuur 4.3 blijkt dat de HBO-afgestudeerden als geheel qua competenties behoorlijk goed toegerust zijn voor hun huidige functie. $60 \%$ vindt dan ook dat de werkgever hun capaciteiten voldoende benut. Van de MBO'ers vindt $64 \%$ dat hun capaciteiten voldoende worden ingezet. Voor de competenties die nu nog bij een deel van de HBO'ers ontbreken, biedt volgens $79 \%$ de gevolgde opleiding wel voldoende basis om de benodigde kennis en vaardigheden alsnog te ontwikkelen. $68 \%$ van de MBO'ers is het wat dat betreft met de HBO'ers eens.

\section{Andere generatie, andere wensen}

Bedrijven die de huidige generatie HBO-/W0-opgeleiden willen binnenhalen, zullen er rekening mee moeten houden, dat deze generatie andere wensen heeft dan de voorgaande generaties. Denk hierbij aan zaken als flexibele arbeidstijden, thuiswerken en werken in deeltijd. Bedrijven die niet bereid zijn om in te spelen op deze wensen, kunnen bij (toekomstige) arbeidsmarktkrapte wel eens achter het net vissen.

\subsection{Ontwikkeling competenties door scholing}

Veel bedrijven in de Metalektro zien het deelnemen aan trainingen en cursussen (samengevat aangeduid met 'scholing') als één van de belangrijkste manieren om de kennis en vaardigheden van hun personeel te verdiepen en te verbreden. In deze paragraaf wordt achtereenvolgens ingegaan op de gemiddelde scholingsdeelname per bedrijf, de ontwikkeling van de scholingskosten, de inhoud van de trainingen en cursussen, de potentiële belemmeringen die bedrijven bij hun scholingsactiviteiten ervaren en ten slotte de manieren waarop het volgen van trainingen en cursussen door de bedrijven wordt gestimuleerd.

\section{Trainings- en cursusdeelname en bijbehorende kosten}

Dit jaar is de bedrijven voor het eerst gevraagd om aan te geven hoe de trainings- en cursusdeelname over hun personeel verdeeld is naar het soort dienstverband. In figuur 4.4 is te zien dat bedrijven hun scholingsinspanningen het meest aanbieden aan hun 
technici in vaste dienst: gemiddeld heeft in elk metalektrobedrijf $57 \%$ van alle technici met een vast dienstverband in 2010 een training of cursus gevolgd. Daarnaast is $24 \%$ van de technici met een tijdelijk dienstverband op cursus geweest en IO\% van de uitzendkrachten en gedetacheerden.

Figuur 4.4

Gemiddelde trainings- en cursusdeelname technische werknemers per type dienstverband
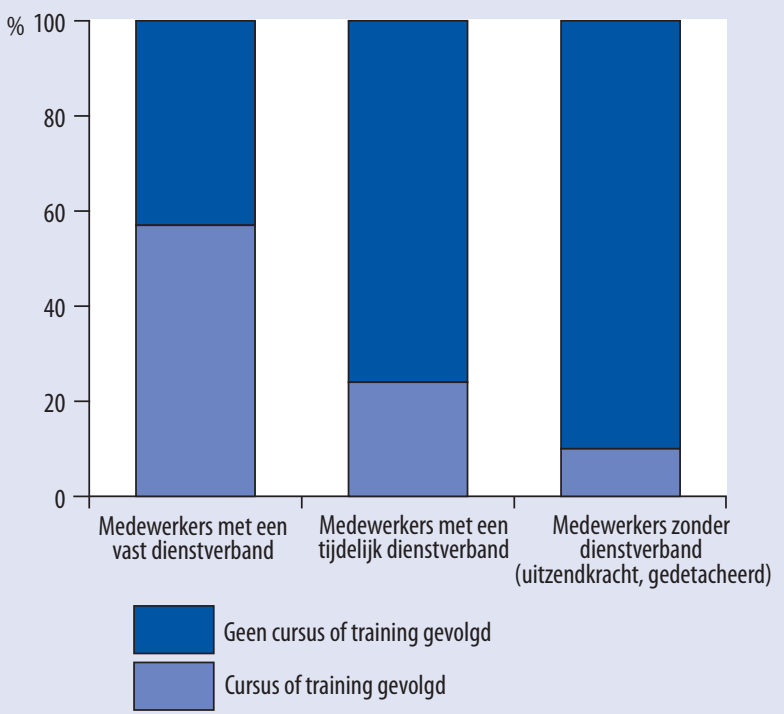

Bron: ROA / Werkgeverspanel Metalektro 2010

In de afgelopen jaren zijn bedrijven in de Metalektro steeds vaker gebruik gaan maken van de flexibele arbeid in de vorm van werknemers met een tijdelijk dienstverband, uitzendkrachten en gedetacheerden. Deze zogenaamde flexibele schil is in de crisis gebruikt om mee te ademen met de neergaande conjunctuur en wordt nu in diverse bedrijven weer opgebouwd (zie hoofdstuk 2). Door het toegenomen belang van de flexibele schil in de metalektrobedrijven bepaalt de kwaliteit van de 'flexibele' werknemers steeds meer de kwaliteit van het totale personeelsbestand. Daarom is het trainen van de werknemers in de flexibele schil ook van belang. De mate waarin en op welke competenties getraind moet worden, is echter afhankelijk van de kwaliteiten die deze werknemers bezitten bij aanvang van hun werkzaamheden en de scholing die zij via andere kanalen (uitzendbureau of detacheringsbureau) aangeboden krijgen. 


\section{Leren on-the-job effectief instrument voor het verwerven van specifieke kennis}

Volgens een metalektrobedrijf is het leren on-the-job de beste leermethode voor productiepersoneel tot maximaal een MBO-opleiding. Dit komt enerzijds doordat bepaalde kennis en vaardigheden zo specifiek zijn voor het bedrijf dat ze niet op school geleerd kunnen worden en die je alleen kunt leren door de kunst af te kijken van ervaren werknemers. Anderzijds biedt leren on-the-job de mogelijkheid tot het veelvuldig herhalen van dezelfde handeling die in het regulier onderwijs ontbreekt. Voor de ontwikkel- en staffuncties (doorgaans op HBO-niveau) is het on-thejob leren daarentegen van minder groot belang, omdat deze personen voor de uitvoering van hun functie via hun initiële opleiding al voldoende kennis hebben opgedaan.

\section{Figuur 4.5}

Ontwikkeling gemiddelde totale opleidingskosten per bedrijf als percentage van de loonsom (bovenste deel figuur) en in euro's (onderste deel figuur)
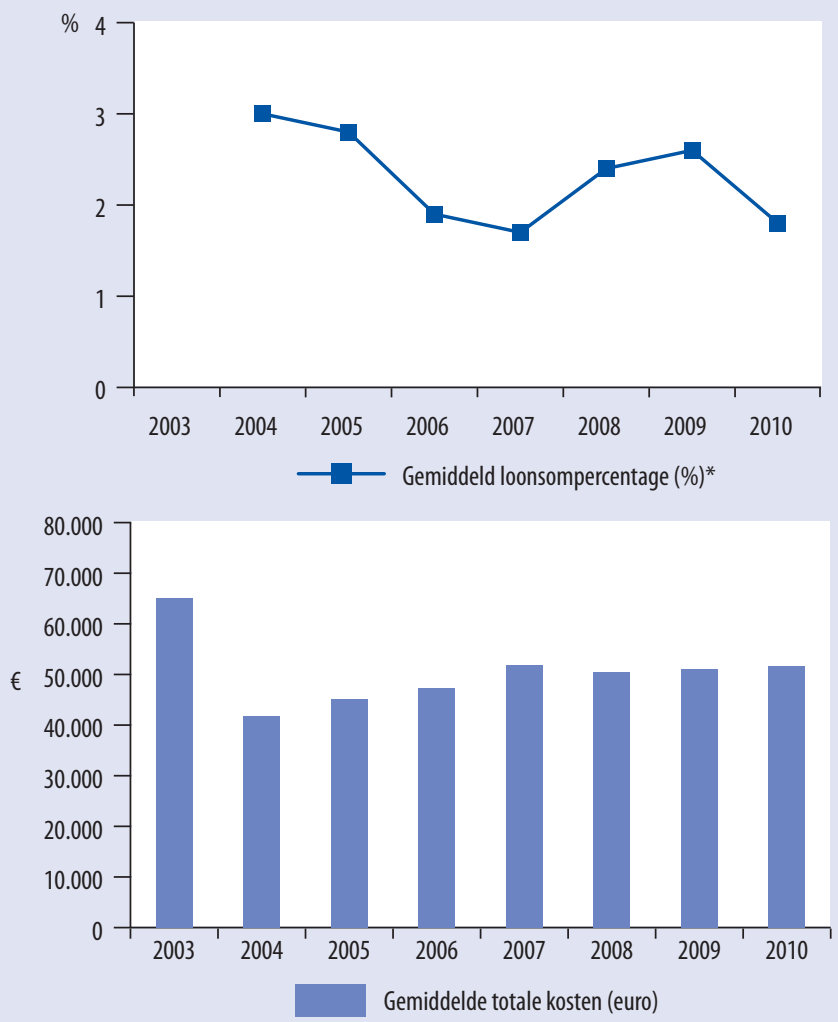

* De totale opleidingskosten als percentage van de loonsom wordt pas sinds 2004 gevraagd, vandaar dat het percentage voor 2003 ontbreekt.

Bron: ROA / Werkgeverspanel Metalektro 2003-2010

De trainingen en cursussen die de bedrijven aan hun technische werknemers met en zonder dienstverband aanbieden, zijn verre van gratis. Figuur 4.5 geeft de ontwikkeling 
van de bijbehorende opleidingskosten weer sinds het begin van de Arbeidsmarktmonitor Metalektro. Het gaat om de zogenaamde totale out-of-pocket kosten per bedrijf. In het bovenste deel van de figuur staan deze totale kosten als percentage van de loonsom weergegeven en in het onderste deel in euro's. De totale out-of-pocket kosten in euro's schommelen al sinds 2007 rond de $€ 50.000$. Als percentage van de loonsom zijn deze kosten wat minder stabiel: na een daling in de periode 2004-2007 van 3\% naar I,7\% volgde een stijging naar $2,6 \%$ in 2009 . Vorig jaar gaven bedrijven echter weer relatief minder aan scholing uit, namelijk I,8\% van de loonsom.

\section{Inhoud trainingen en cursussen}

De in 2010 door technici gevolgde trainingen en cursussen zijn in de helft van de bedrijven (57\%) meestal op initiatief van de direct leidinggevende gevolgd. Bij $27 \%$ lag het initiatief meestal bij het management en bij I $6 \%$ is het doorgaans de werknemer die het initiatief neemt. Ten opzichte van de vorige meting betekenen deze cijfers een lichte verschuiving van het initiatief van de werknemer naar de direct leidinggevende. Het overgrote deel van de cursussen $(72 \%)$ wordt overigens gevolgd om goed te kunnen (blijven) functioneren in de huidige functie. Een kwart is gericht op de loopbaanontwikkeling van de technici binnen het eigen bedrijf en de resterende $3 \%$ is bedoeld om de technici in kwestie voor te bereiden op een voortzetting van hun loopbaan buiten het huidige bedrijf. Deze cijfers zijn vrijwel gelijk aan die uit de vorige monitor.

Gelet op het hoge percentage trainingen en cursussen dat gericht is op de huidige functie, is het niet verwonderlijk dat vaktechnische vaardigheden in 2010 veruit het vaakst op het cursusmenu stonden: $77 \%$ van de bedrijven heeft technici naar een dergelijke cursus gestuurd (zie figuur 4.6). De top 3 wordt verder ingevuld door de cursussen leidinggeven (39\%) en communicatieve vaardigheden (32\%). Opvallend is dat bedrijven in paragraaf 4.I aangeven dat de gedragsmatige competenties zoals de PROFIcompetenties belangrijker zullen worden, maar hun technici nauwelijks naar cursussen hebben gestuurd waarin deze competenties centraal staan. Probleemoplossend vermogen is met $8 \%$ van de bedrijven nog de competentie waar het meest op getraind wordt.

Deze schijnbare paradox kan op een aantal manieren worden verklaard. De eerste verklaring luidt dat deze competenties weliswaar belangrijker worden in de technische functies, maar dat deze al voldoende in de huidige technici aanwezig zijn. Gelet op o.a. de antwoorden van de HBO'ers in paragraaf 4.2, is deze verklaring op zijn best een deel van de verklaring. Een tweede verklaring is dat de bewuste gedragsmatige competenties wellicht effectiever geleerd kunnen worden buiten het cursus- of trainingslokaal, bijvoorbeeld door mee te lopen met een meer ervaren collega. Een derde verklaring kan worden gezocht in de aanname dat bepaalde gedragsmatige competenties moeilijk te leren zijn, maar in aanleg in een persoon aanwezig moet zijn (zoals initiatief). Indien een dergelijke aanname correct is, is een op dergelijke competenties gericht wervings- en selectiebeleid waarschijnlijk effectiever dan het laten volgen van trainingen en cursussen. 
Figuur 4.6 laat zien dat de trainingen en cursussen die de technici in 20II zullen gaan volgen, qua thema's vergelijkbaar zijn met de in 2010 gevolgde cursussen. Ook in $201 \mathrm{I}$ zal de top 3 bestaan uit vaktechnische vaardigheden, leiding geven en communicatieve vaardigheden. Daarnaast zullen bedrijven in 20II, in vergelijking tot 20IO, iets meer aandacht besteden aan de thema's veilig gedrag, probleemoplossend vermogen en omgaan met veranderingen. De aandacht voor enkele van de PROFI-competenties neemt dus toe in het komende jaar.

\section{Figuur 4.6}

Inhoud gevolgde trainingen en cursussen in 2010 en inhoud geplande trainingen en cursussen in 2011 (\% bedrijven)

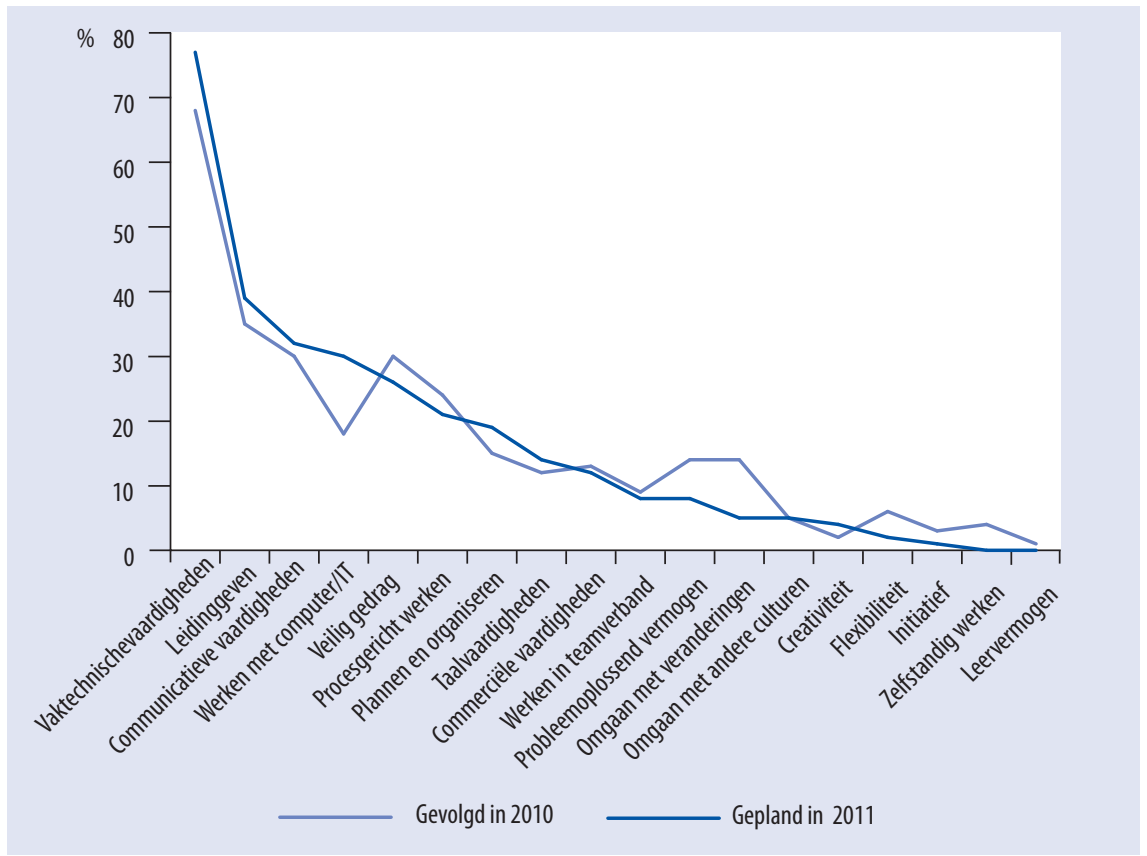

Bron: ROA / Werkgeverspanel Metalektro 2010

\section{Belemmeringen die bedrijven ervaren bij het opleiden}

Figuur 4.4 heeft eerder laten zien dat lang niet alle in de sector werkzame technici vorig jaar een cursus of training gevolgd hebben. Het is natuurlijk mogelijk dat bepaalde technici geen training nodig hadden. Het is echter waarschijnlijker dat bedrijven meer technici hadden willen trainen dan ze hebben gedaan, maar tegen bepaalde belemmeringen zijn aangelopen. Figuur 4.7 geeft een beeld van de redenen om (een deel van) het personeel niet aan trainingen of cursussen te laten deelnemen.

Het meest genoemde struikelblok betreft het tijdsaspect: $29 \%$ van de bedrijven zegt dat cursussen te veel tijd kosten en $15 \%$ vindt dat cursussen op momenten worden 
gegeven die hen slecht uitkomen. Het regelen van vervanging weerhoudt één op de vijf om (meer) personeel naar een cursus of training te laten gaan. Een ander euvel betreft de inhoud van het cursusaanbod: die sluit niet aan op de behoefte (I3\%), wijkt te veel af van de werkpraktijk (I2\%) of van het kennisniveau van de technici (8\%).

Figuur 4.7

Belemmeringen deelname aan trainingen en cursussen (\% bedrijven)

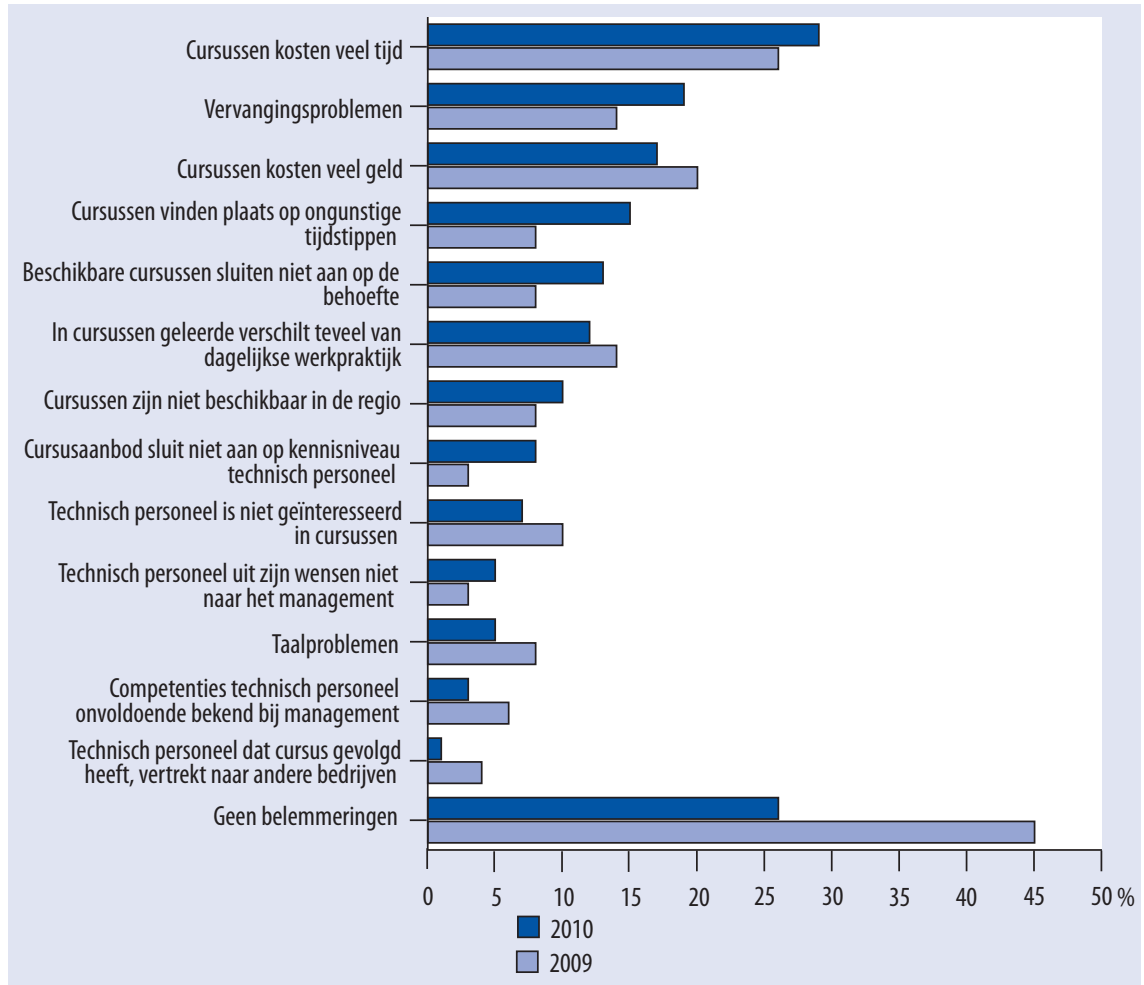

Bron: ROA / Werkgeverspanel Metalektro 2009-2010

Bedrijven ervaren het tijdsaspect in 2010 iets vaker als een belemmering dan in 2009: in 2010 geven meer bedrijven aan dat cursussen veel tijd kosten, vervangingsproblemen een rol spelen en cursussen op ongunstige tijdstippen plaatsvinden. Dit heeft waarschijnlijk te maken met de toegenomen bedrijvigheid in de bedrijven die uit de crisis aan het geraken zijn.

\section{Stimuleren van deelname aan trainingen en cursussen}

Ondanks de belemmeringen proberen bedrijven hun personeel te stimuleren om aan trainingen en cursussen deel te nemen. Opleiding en ontwikkeling ter sprake brengen tijdens het functioneringsgesprek is met $55 \%$ het meest genoemde stimuleringsinstrument. Ruim 
een derde betrekt de direct leidinggevende bij het enthousiasmeren van de werknemer voor het volgen van een training of cursus en $3 \mathrm{I} \%$ probeert werknemers elkaar onderling enthousiast te laten maken hiervoor. In een kwart van de bedrijven spannen de P\&O-ers zich in om werknemers aan het leren te krijgen en ongeveer eenzelfde percentage probeert dit via een leerrijke werkomgeving te bewerkstelligen.

\begin{abstract}
Werk maken van subsidies loont...
In figuur 4.7 geeft een deel van de bedrijven aan dat de cursuskosten een belemmering vormen om (meer) werknemers scholing te laten volgen. Eén van bedrijven heeft daarom iemand binnen het bedrijf viijgemaakt om zich te verdiepen in de beschikbare subsidies en fiscale mogelijkheden en de benodigde aanvragen in te dienen. Na dit voorwerk bleek het doen van vervolg- of nieuwe aanvragen een fluitje van een cent. Door deze werkwijze heeft het bedrijf ongeveer $30-40 \%$ van haar opleidingskosten kunnen financieren. Daarnaast is dit bedrijf bezig om via de grote groep waartoe het behoort een aanvraag in te dienen voor subsidies vanuit het Europees Sociaal Fonds (ESF). 0ok is het mogelijk om via $\mathrm{A}+0$ van dergelijke ESF-subsidies gebruik te maken.

... maar soms knellen de wettelijke kaders

Om cursussen ook qua inhoud en tijd beter aan te laten sluiten op de vraag van de bedrijven zou er meer ingezet moeten worden op het aanbieden van opleidingsmodules en op het leren on-the-job. Voor dergelijke leertrajecten kunnen bedrijven echter moeilijk aan subsidies komen 0.a. doordat de huidige onderwijswetgeving subsidiering van dergelijke opleidingstrajecten niet toelaat.
\end{abstract}

\title{
4.4 Ontwikkeling competenties door interne mobiliteit
}

Er zijn vele wegen die naar Rome leiden, luidt een oud gezegde en dat gaat zeker op voor het ontwikkelen van competenties en loopbanen van technici in de Metalektro. Trainingen en cursussen zijn een weg om dit doel te bereiken, maar zeker niet de enige weg. Zoals eerder in dit hoofdstuk opgemerkt, worden (nog) niet veel cursussen en trainingen gevolgd waarin de PROFI-competenties centraal staan (zie paragraaf 4.3), terwijl het belang ervan voor de technische functies wel zal toenemen (zie paragraaf 4.I). Deze schijnbare paradox is in paragraaf 4.3 o.a. verklaard door te wijzen op de mogelijke ongeschiktheid van trainingen en cursussen om deze gedragsmatige competenties aan te leren. Het leren door te doen, oftewel learning-on-the-job is wellicht een betere leermethode voor deze en andere competenties. Ook kunnen trainingen en cursussen überhaupt niet geschikt zijn voor bepaalde groepen werknemers, bijvoorbeeld voor hen die door eerdere slechte (school)ervaringen negatief staan tegenover deze vorm van leren. Deze groep zal dan ook eerder leren door te doen dan door deelname aan een cursus of training.

Learning-on-the-job kent vele vormen, zowel tijdelijke (functieroulatie, tijdelijke opdrachten op een andere afdeling) als meer permanente vormen. In deze paragraaf wordt gekeken naar de meest permanente variant, namelijk het intern doorstromen naar 
een andere functie door de technische werknemers. In de vorige Arbeidsmarktmonitor Metalektro bereikte de interne mobiliteit een historisch dieptepunt: in slechts $36 \%$ van de bedrijven was sprake van interne doorstroom, het laagste percentage sinds dit in 2005 voor het eerst werd gemeten. Hoe is dit nu? Inmiddels stromen in iets meer dan de helft $(56 \%)$ van de bedrijven technici intern door naar andere functies. $32 \%$ heeft uitsluitend technici die doorstromen naar andere technische functies, terwijl in $21 \%$ technici naar zowel technische als niet-technische functies doorstromen.

Wanneer technici intern doorstromen, kan er sprake zijn van verticale of horizontale mobiliteit. Van verticale mobiliteit is sprake als de nieuwe functie een hoger of lager niveau heeft dan de oude functie. Bij horizontale mobiliteit zijn de nieuwe en de oude functie van hetzelfde niveau. Figuur 4.8 laat zien dat in de bedrijven waar technici intern doorstromen, deze werknemers in iets meer dan de helft van de gevallen op hetzelfde functieniveau blijven acteren. Technici die naar een andere technische functie doorstromen, krijgen vaker een functie op een hoger niveau dan technici die doorstromen naar een niet-technische functie (44\% tegenover 36\%). Demotie oftewel een functie op een lager niveau, komt overigens zeer weinig voor.

\section{Figuur 4.8}

Interne mobiliteit van het technisch personeel naar type functie en functieniveau ${ }^{9}$

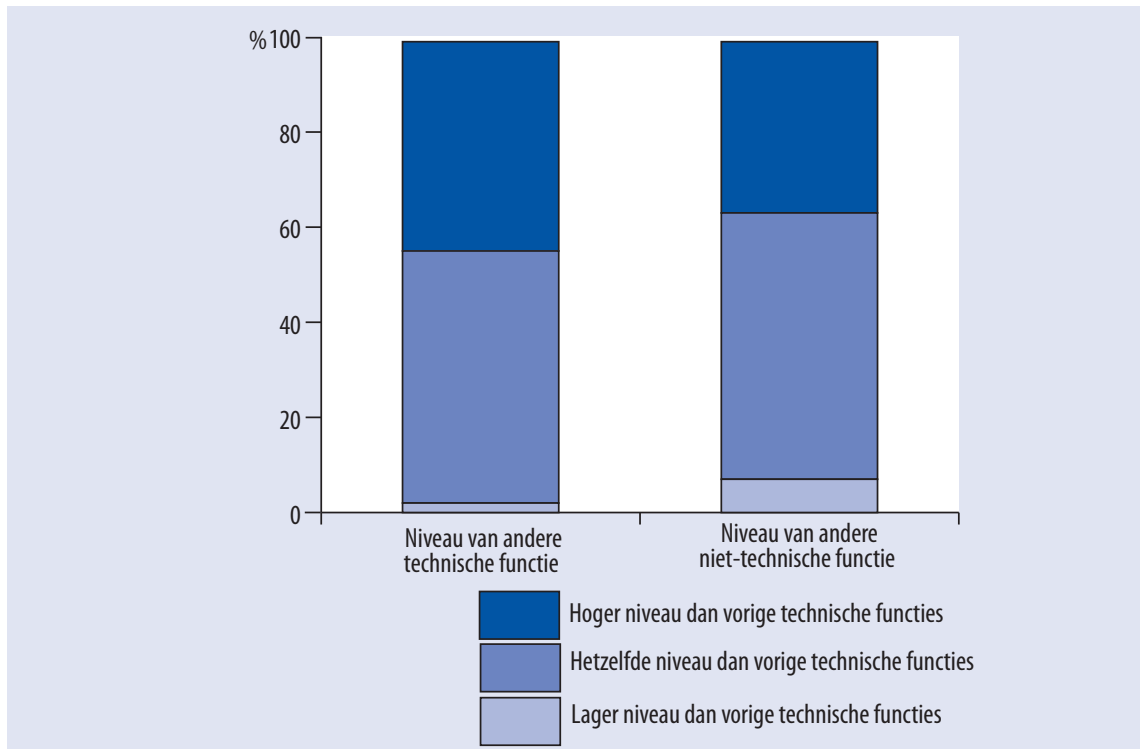

Bron: ROA / Werkgeverspanel Metalektro 2010

9. Deze figuur wijkt sterk af van figuur 4.I2 in de vorige Monitor door een wijziging in de vraagstelling. Dit jaar is aan de bedrijven met interne doorstroom gevraagd om aan te geven welk percentage van het doorgestroomde personeel naar een functie met een hoger, hetzelfde en een lager niveau is doorgestroomd. 
Vier op de vijf bedrijven zijn, net als vorig jaar, tevreden over de mate van interne mobiliteit in hun bedrijf. De rest had liever wat meer doorstroom gehad. Bedrijven geven aan dat de interne doorstroom voornamelijk beperkt wordt door het ontbreken van voldoende hogere functies $(32 \%)$ en het te lage kennisniveau van het personeel (25\%). In sommige gevallen speelt ook de drukte op het werk een rol of willen direct leidinggevenden hun goed functionerende technici liever niet laten gaan.

\section{Leidinggevende technici: balanceren tussen technische kennis en leiderschapskwaliteiten}

De beste technici zijn niet altijd de beste leidinggevenden. Dit is 0.a. te wijten aan:

- het gebrek aan leidinggevende capaciteiten (en deze soms ook niet willen ontwikkelen);

- het hebben van een onjuist beeld van wat een leidinggevende functie inhoudt;

- het zich blijven gedragen als technicus, het vakgebied niet los kunnen laten met als gevolg dat het leidinggeven 'erbij wordt gedaan'.

Het is daarom raadzaam om potentiële kandidaten eerst te testen op de benodigde leidinggevende kwaliteiten alvorens hen de leidinggevende positie daadwerkelijk aan te bieden. Het aanstellen van iemand van buiten het bedrijf die al over leidinggevende kwaliteiten beschikt, maar inhoudelijk veel minder weet dan de teamleden, is overigens ook niet altijd de beste oplossing. In een dergelijke situatie kan het de leidinggevende veel moeite kosten om door het team geaccepteerd te worden. Deze gebrekkige acceptatie kan het functioneren van de leidinggevende behoorlijk beperken.

\subsection{HRM-instrumenten: een totaaloverzicht}

In de voorgaande paragrafen is ingegaan op een deel van het instrumentarium dat metalektrobedrijven tot hun beschikking hebben om de competenties van hun personeel te ontwikkelen. Zo is aandacht besteed aan het vaststellen van de huidige competenties en het bepalen van de benodigde competenties (paragraaf 4.I) en aan het ontwikkelen van competenties door scholing (zie paragraaf 4.3) en interne mobiliteit (zie paragraaf 4.4). In deze paragrafen is steeds geredeneerd vanuit de behoeften van het bedrijf. Echter, wanneer de competenties van werknemers vastgesteld en ontwikkeld worden, heeft dit tegelijkertijd invloed op hun individuele loopbanen. De metalektrobedrijven kunnen competentiemanagement dus ter ondersteuning van het loopbaanmanagement van hun personeel gebruiken.

In de nu volgende paragraaf wordt een totaalbeeld geschetst van de HRM-instrumenten die in 2010 door bedrijven in de Metalektro toegepast worden, geordend naar een aantal onderdelen van de loopbaanmanagementcyclus. De hier gebruikte loopbaanmanagementcyclus bestaat uit de stappen assessment, vastleggen doelen en acties, scholing en werkervaring opdoen. Wat assessment oftewel het vaststellen van de huidige kennis en vaardigheden van het personeel betreft, is de informatie uit het functioneringsgesprek voor de meeste bedrijven de aangewezen databron. Dit instru- 
ment wordt van de instrumenten die geschikt zijn voor assessmentdoeleinden immers het meest gebruikt.

Ontwikkelafspraken worden in $55 \%$ van de bedrijven gemaakt en vastgelegd in het persoonlijk ontwikkelingsplan (POP), een instrument dat in de afgelopen twee jaar aanzienlijk populairder is geworden. Deze toename in het gebruik heeft mogelijk te maken met de voorwaarden van de regelingen wtv en deeltijd-ww en de subsidies van de O\&O-fondsen. Een derde stelt een opleidingsplan voor het gehele bedrijf op, het zogenaamde bedrijfsopleidingsplan (BOP) en I6\% gebruikt een competentiemanagementsysteem. In een derde van de bedrijven worden ontwikkelafspraken niet vastgelegd in POP's, BOP's of in een competentiemanagementsysteem.

\section{Figuur 4.9}

HRM-instrumenten (\% bedrijven)

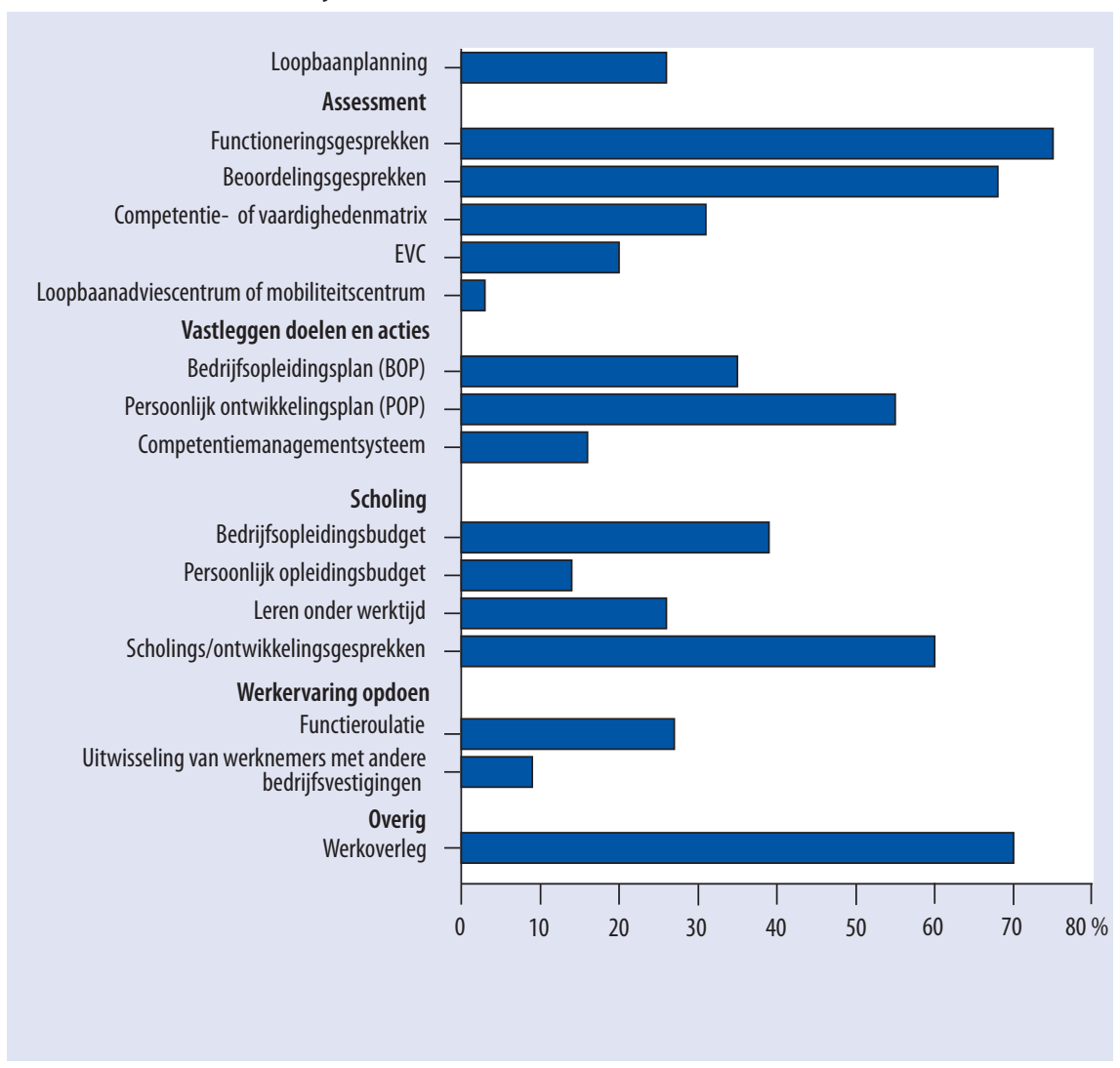

Bron: ROA / Werkgeverspanel Metalektro 2010

Scholing is al uitgebreid aan bod geweest in paragraaf 4.3. Zo is daar o.a. besproken waar de cursussen over gaan, wie er deelnemen en wat de kosten zijn. In figuur 4.9 
is te zien op welke manieren de bedrijven het leren van hun personeel faciliteren met tijd en geld. Zo heeft ongeveer $40 \%$ van de bedrijven een bedrijfsopleidingsbudget en geeft I $4 \%$ haar werknemers de beschikking over een persoonlijk opleidingsbudget. Een kwart laat haar werknemers leren onder werktijd. De helft van de bedrijven biedt overigens geen van deze drie faciliteiten aan.

In paragraaf 4.4 is ingegaan op interne mobiliteit als de meest permanente manier van learning-on-the-job. Tijdelijke constructies die technici in staat stellen om tijdens het werk ervaring op te doen, zijn functieroulatie en het uitwisselen van werknemers met andere vestigingen. Uit figuur 4.9 blijkt dat in een kwart van de bedrijven functieroulatie voor komt. Slechts één op de elf wisselt personeel uit met andere vestigingen. Dit lage percentage is niet zo verwonderlijk als men bedenkt dat het gros van de metalektrobedrijven slechts één vestiging heeft en deze uitwisselingsmogelijkheid dan eenvoudigweg niet aanwezig is.

Samengevat zijn er in behoorlijk wat bedrijven momenteel instrumenten in gebruik die geschikt zijn voor competentie- en/of voor loopbaanmanagement. Net als vorig jaar is in een kwart van de bedrijven sprake van loopbaanplanning. In hoofdstuk 7 wordt overigens ingegaan op de instrumenten die men in de komende vijf jaar denkt te gaan inzetten en welke speerpunten men daarmee wil realiseren (zie paragraaf 7.4 ).

Gelet op de levensfase waarin een werknemer zich bevindt of de leeftijd die men heeft, kan het wenselijk zijn om bepaalde ontwikkelingsinstrumenten en aanpassingen van het werk juist wel of juist niet aan te bieden. Vandaar dat van een aantal is onderzocht of metalektrobedrijven het aanbod ervan differentiëren naar werknemers onder en boven de 45 jaar. Voor alle instrumenten en aanpassingen geldt dat indien zij worden aangeboden, zij meestal aan iedereen in gelijke mate worden aangeboden. Toch zijn er wel enige verschillen. Zo wordt gedeeltelijk ander werk in $\mathrm{I} 6 \%$ van de bedrijven relatief vaker aan 45 -plussers aangeboden tegenover slechts $5 \%$ dat dit vaker aan 45 -minners aanbiedt. Ook werk waarbij kennisoverdracht centraal staat, wordt, indien er gedifferentieerd wordt, vaker aan de oudere dan aan de jongere werknemer aangeboden: I5\% biedt dit vaker aan 45 -plussers aan tegenover $3 \%$ dat dit vaker aan 45 -minners aanbiedt. Aan de andere kant is te zien dat opleidingsmogelijkheden, loopbaangesprekken en taakroulatie, indien er sprake is van differentiatie, vaker aan de jongere werknemer wordt aangeboden. Bijna een kwart van de bedrijven biedt vooral de 45-minner loopbaangesprekken aan, bij I4\% rouleren voornamelijk de jongeren van taak en bij I3\% zijn het vooral de jongere werknemers die opleidingsmogelijkheden krijgen aangeboden. In het licht van het zo lang mogelijk productief houden van de oudere werknemers, lijkt dit een gegeven dat in de gaten gehouden moet worden. Immers opleiding, taakroulatie en in gesprek met elkaar gaan over de loopbaan, zijn bij uitstek manieren om de competenties van de oudere werknemer up-to-date te houden zodat deze werknemer zijn productiviteit en werkplezier behoudt. 


\section{Sociale innovatie}

De metalektrobedrijven lijken over vrijwel de hele linie van sociale innovatie een time-out te hebben genomen: er worden minder veranderingen doorgevoerd dan in de twee voorgaande jaren. De bedrijven hebben nog wel dezelfde voorkeuren als voorheen: zowel bij de al geïplementeerde veranderingen als de toekomstige veranderingen springen het variabel inzetten van technici, projectmatig werken en samenwerken met een ander bedrijf eruit. De evaluaties wijzen uit dat dergelijke veranderingen de nodige tijd kosten. Deze veranderingen en zaken als conjuncturele schommelingen en technologische innovaties vragen om breed inzetbaar personeel. Dat is meestal wel beschikbaar, maar een derde van de bedrijven heeft een tekort aan breed inzetbare uitvoerende technici. Bedrijven besteden activiteiten vaker uit aan bedrijven in Nederland dan aan bedrijven in het buitenland. De activiteiten die aan het buitenland worden uitbesteed, betreffen productieactiviteiten.

\subsection{Organisatie en management}

Sociale innovatie heeft als voornaamste doel de bedrijfsprestaties te verbeteren en de talenten van de medewerkers te ontplooien en betreft veranderingen op het gebied van:

- Organisatie en management: innovaties die vooral betrekking hebben op de manier waarop het werk wordt georganiseerd, wie waarvoor verantwoordelijk is en hoe het bedrijf door het management wordt geleid.

- Het menselijk kapitaal van het bedrijf: innovaties waardoor het menselijk kapitaal beter kan worden benut binnen het bedrijf en innovaties waardoor dit kapitaal verder ontwikkeld kan worden.

- Nieuwe vormen van samenwerking in de bedrijfsomgeving: allianties met andere bedrijven, samenwerking met leveranciers, klanten en kennisorganisaties.

In deze paragraaf besteden we uitgebreid aandacht aan de innovaties op het gebied van de organisatie en het management die door de metalektrobedrijven in het recente verleden zijn geïmplementeerd én welke zij in de komende jaren zullen implementeren. Het menselijk kapitaal komt in paragraaf 5.2 aan bod en in paragraaf 5.3 staat externe samenwerking centraal.

De metalektrobedrijven zijn in 2010 qua organisatorische veranderingen minder actief geweest dan in 2009. In figuur 5.I is namelijk te zien dat $38 \%$ van de bedrijven 
aangeeft in 2010 geen verandering te hebben doorgevoerd. Dat betekent dat $62 \%$ in 2010 wel minimaal één verandering heeft doorgevoerd. In 2009 bedroeg dit percentage echter $91 \%$. De meestgenoemde organisatorische verandering betreft het variabel inzetten van de eigen technici, dat wil zeggen de technici die in dienst zijn van het bedrijf. Een derde van de bedrijven zet haar eigen technici variabel in, wat voornamelijk inhoudt dat technici soms meer dan één functie vervullen. Dit sluit goed aan bij de gedachte uit paragraaf 4.4 dat mensen competenties kunnen leren die bij een andere functie horen door deze functie (soms) uit te voeren.

Het variabel inzetten van technici gebeurt ook door hen te laten beginnen en eindigen op verschillende werktijden. $28 \%$ van de bedrijven is vorig jaar begonnen met projectmatig werken en een kwart is gaan samen werken met een externe partij. Deze samenwerkende bedrijven hebben vrijwel allemaal een ander bedrijf (zijnde een concullega, klant of leverancier) als partner en ongeveer de helft werkt (ook) samen met een kennisinstelling. Verder heeft ongeveer één op de vijf zich bezig gehouden met werken in teams, waarbij het vaker om multifunctionele dan zelfsturende teams gaat. Veranderingen die genoemd worden in de categorie 'Anders' zijn onder andere wijzigingen in het management of fusies. Hoewel bedrijven in 2010 minder vaak een organisatorische verandering hebben doorgevoerd dan in 2009, blijven vrijwel dezelfde veranderingen populair: ook in 2009 waren variabele inzet van personeel en projectmatig werken de meestgenoemde veranderingen.

Figuur 5.1

Organisatorische veranderingen geïmplementeerd (\% bedrijven)

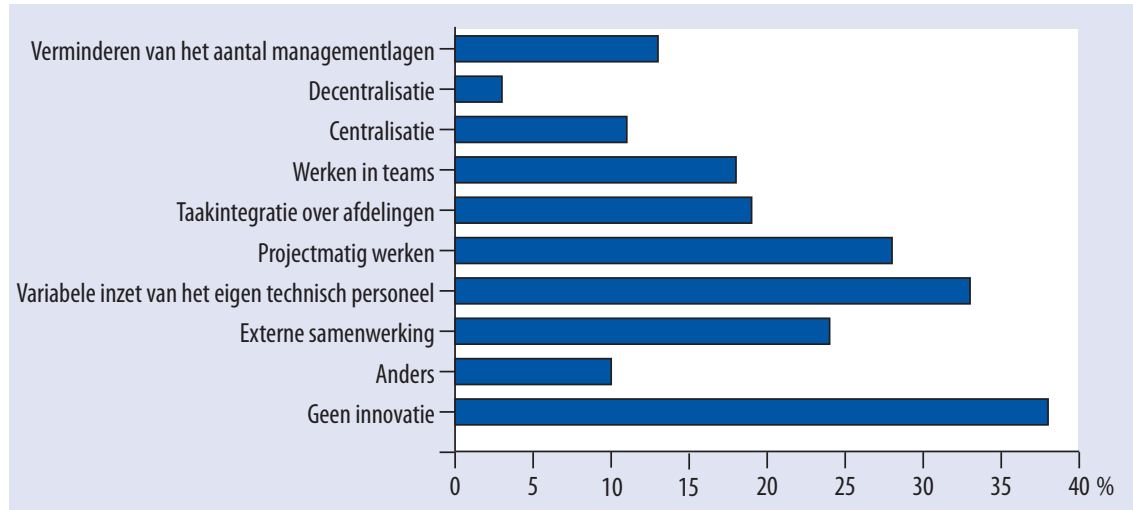

Bron: ROA / Werkgeverspanel Metalektro 2010

\section{Organisatorische veranderingen geëvalueerd}

Het implementeren van organisatorische veranderingen gaat niet altijd van het spreekwoordelijke leien dakje. Om inzicht te krijgen in de mate waarin bedrijven tegen obstakels oplopen en welke obstakels dat zijn, is bedrijven gevraagd hoe het implementatieproces van de betreffende verandering tot nu toe verloopt. Figuur 5.2 
laat zien dat het doorvoeren van organisatorische veranderingen een zaak van de lange adem is: minimaal een derde van sommige veranderingen is nog niet volledig door de bedrijven geïmplementeerd en dit loopt op tot twee derde bij de bedrijven die met werken in teams aan de slag zijn gegaan. Van deze nog lopende veranderingen is het nog niet mogelijk om al een eindoordeel te geven. Van de afgeronde veranderingen blijken de meeste volgens plan verlopen te zijn. Alleen van de bedrijven die het aantal managementlagen verminderd hebben, geeft een substantieel deel aan dat de implementatie niet volgens plan is verlopen. Ook het integreren van taken over afdelingen levert soms problemen op. Gelet op het feit dat de implementatie van de meeste veranderingen doorgaans naar wens is verlopen, is het niet verwonderlijk dat ook bijna alle volledig geïmplementeerde veranderingen nog steeds van kracht zijn. Alleen in het geval van het variabel inzetten van personeel, projectmatig werken en externe samenwerking geven enkele bedrijven aan dat de verandering gedeeltelijk is teruggedraaid.

Figuur 5.2

Evaluatie van geïmplementeerde organisatorische veranderingen (\% van bedrijven die de betreffende verandering hebben doorgevoerd)

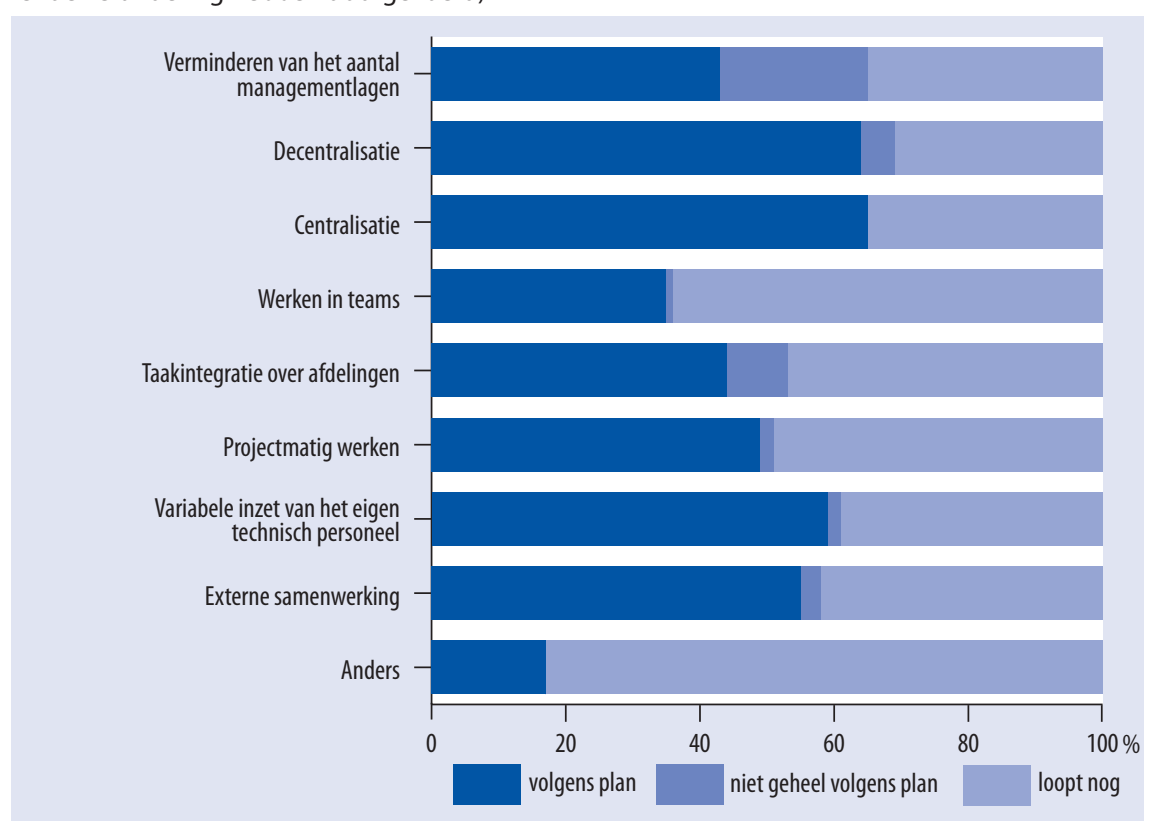

Bron: ROA / Werkgeverspanel Metalektro 2010 


\section{Goed voorbeeld doet goed volgen, juist bij fouten}

De kans op fouten is altijd aanwezig, zeker wanneer er geïnnoveerd wordt. Na constatering van een fout is het van groot belang dat er niet naar een zwartepiet gezocht wordt. Het uitgangspunt is namelijk dat iedereen in het bedrijf zijn best wil doen. Als er fouten worden gemaakt, is er ergens in de organisatie van het werk iets niet goed gegaan. Het is dus veel zinvoller om je als organisatie te richten op het verbeteren van deze werkorganisatie en er op die manier voor te zorgen dat een dergelijke situatie niet meer voor kan komen. Als leidinggevende is het dan van belang om ten eerste zelf het goede voorbeeld te geven en daarnaast niet mee te gaan met werknemers die zelf met'zwartepieten'beginnen, maar hen positief doch consequent in de richting van het oplossen en voorkomen van de ontstane situatie te sturen.

\section{Organisatorische veranderingen in de toekomst}

Een vergelijking tussen de mate van activiteit op het gebied van organisatorische veranderingen in 2010 ten opzichte van 2009 zou kunnen leiden tot de conclusie dat er een soort van sociale-innovatiemoeheid is opgetreden. Na de turbulente jaren 2008 en 2009 waarin bedrijven veelvuldig innoveerden, zijn sommigen nu in wat rustiger vaarwater terecht gekomen. Figuur 5.3 laat zien dat een kwart van de bedrijven het komende jaar in ieder geval even pas op de plaats maakt als het om organisatorische veranderingen gaat en nog eens $20 \%$ doet de komende vijf jaar even niets op dat gebied. Van een algehele stop is dus echter geen sprake. Immers, in figuur 5.3 is te zien dat bijna $40 \%$ in $201 \mathrm{I}$ of in de jaren erna van plan is het personeel variabel in te zetten en eenzelfde percentage start met projectmatig werken. Werken in teams, het integreren van taken over afdelingen en externe samenwerking staan elk bij ongeveer een kwart op de agenda voor $201 \mathrm{I}$ of voor de vier jaren erna.

\section{Figuur 5.3}

Geplande organisatorische veranderingen in de komende vijf jaar (\% bedrijven)

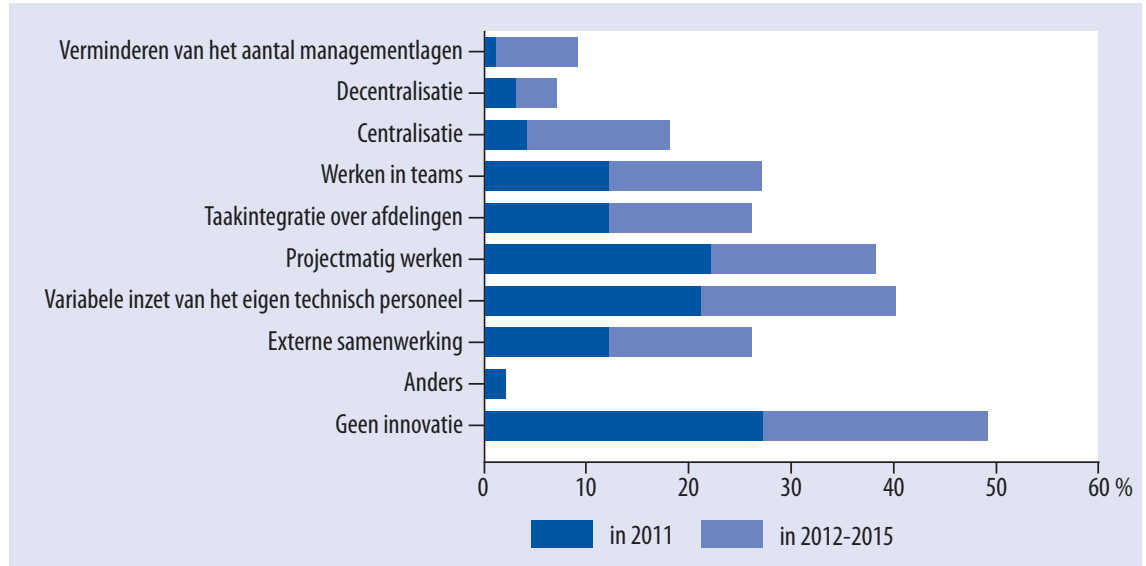

Bron: ROA / Werkgeverspanel Metalektro 2010 
Opvallend is overigens dat bij de vijf meestgenoemde veranderingen het aandeel bedrijven dat de verandering op korte termijn (20II) wil invoeren, ongeveer gelijk is aan het deel dat deze verandering pas in 20I2-20I5 oppakt. In de vorige Arbeidsmarktmonitor Metalektro was te zien dat een ruime meerderheid van de bedrijven de dan geplande veranderingen al op korte termijn wilde gaan implementeren. De 'sense of urgency' lijkt er dus wel een beetje uit te zijn.

\section{Hardware inzetten om de software te veranderen...}

Het veranderen van de manier van werken (software) is geen eenvoudige opgave. Niet zelden reageren werknemers als door een wesp gestoken, want 'hebben we het dan al die jaren fout gedaan?!'. Soms is het antwoord op die vraag ronduit 'ja', maar vaker zijn dergelijke veranderingen het gevolg van nieuwe technologie of nieuwe kennis oftewel voortschrijdend inzicht. Een bedrijf dat fuseerde merkte dat het gelijktijdig implementeren van een identiek automatiserings- en administratiesysteem (hardware) bij de fusiepartners leidde tot een snelle harmonisatie van de werkwijze van de werknemers die met deze systemen werkten.

\section{... en werk volgens het principe 'het hemd is nader dan de rok'}

Serieus luisteren naar de zorgen en bezwaren van de werknemers tegen een nieuwe, andere werkwijze is net zo belangrijk als het herhaaldelijk uitleggen van het waarom van de nieuwe werkwijze bij het wegnemen van de weerstand onder het personeel. In geval van een fusie blijkt dat de uitleg eerder wordt geaccepteerd van iemand met informeel gezag in de oude organisatie waar nu anders gewerkt moet worden, dan van degenen van buiten die het in de nieuwe organisatie formeel voor het zeggen hebben.

Een vergelijking tussen figuur 5.3 en figuur 5.I laat een aantal opvallende parallellen zien: zo is de rangorde in populariteit van de al geïmplementeerde organisatorische veranderingen vrijwel gelijk aan die van de geplande veranderingen. Variabele inzet van personeel is en blijft de meeste genoemde verandering, gevolgd door projectmatig werken. Externe samenwerking, werken in teams en taakintegratie over afdelingen wisselen onderling enigszins van plaats, maar de verschillen zijn klein. Een tweede parallel bevindt zich op een diepere laag. Waar bedrijven hun eigen technici variabel willen gaan inzetten, met teams willen gaan werken of externe samenwerkingsverbanden willen aangaan, blijken bedrijven voor dezelfde vormen te kiezen als de al in 20 Io geïmplementeerde veranderingen. Dus de variabele inzet van technici houdt in dat technici soms meer dan één functie zullen vervullen, er wordt iets vaker voor multifunctionele dan voor zelfsturende teams gekozen en de voorkeur gaat uit naar samenwerking met een ander bedrijf boven samenwerking met een kennisinstelling. 


\begin{abstract}
Afstanden overbruggen: breng mensen samen bij het ontwikkelen van beleid
In (grote) bedrijven met meerdere vestigingen kan niet alleen letterlijk, maar ook figuurlijk een flinke afstand bestaan tussen het personeel van de ene en de andere vestiging en ook tussen de vestigingen en het hoofdkantoor. Door bij het ontwikkelen van nieuw beleid werknemers en leidinggevenden van verschillende vestigingen in één werkgroep te plaatsen, ontstaan er allerlei persoonlijke dwarsverbanden en kan er van elkaar geleerd worden tijdens, maar ook na het project. Wanneer ook mensen van de centrale HR-afdeling aan deze werkgroepen worden toegevoegd, wordt ook de mogelijk aanwezige kloof tussen deze afdeling en de vestigingen verkleind.
\end{abstract}

\title{
5.2 Benutting en ontwikkeling van menselijk kapitaal
}

Wanneer organisatorische veranderingen plaatsvinden die op zichzelf de bedrijfsprestaties kunnen verbeteren of wanneer deze plaatsvinden om technologische innovaties (beter) te laten renderen, is het van belang om te realiseren dat deze veranderingen er ook toe leiden dat andere of hogere eisen worden gesteld aan wat het menselijk kapitaal in het bedrijf kent en kan. Deze veranderde eisen kunnen leiden tot de te verwachten functieveranderingen die besproken zijn in paragraaf 4.I. In hoofdstuk 4 is al uitgebreid ingegaan op het ontwikkelen van het menselijk kapitaal door scholing (zie paragraaf 4.3) en door interne mobiliteit (zie paragraaf 4.4). Om deze reden ligt de nadruk in de nu volgende paragraaf op de benutting van het menselijk kapitaal in de metalektrobedrijven.

\section{Brede inzetbaarheid}

In paragraaf 4.I is onder andere besproken dat een deel van de bedrijven verwacht dat de technische functies in hun bedrijf meer allround zullen worden, dat technici lager in de organisatie meer verantwoordelijkheden zullen krijgen en dat bepaalde gedragsmatige competenties belangrijker zullen worden. Deze verwachte functieveranderingen zijn in lijn met de in paragraaf 7.4 geformuleerde speerpunten voor het HRM-beleid waar, net als voorgaande jaren, het speerpunt Bevorderen van de inzetbaarheid van het personeel door de meeste bedrijven genoemd wordt. Het kunnen inzetten van het personeel in een breder spectrum is en blijft dus een belangrijk item. 


\section{Breder inzetbaar personeel leidt tot efficiëntere personeelsinzet}

Schommelingen in de bedrijfsdrukte wordt door bedrijven het vaakst genoemd als reden om naar brede inzetbaarheid te streven. Deze schommelingen kunnen voor het bedrijf als geheel gelden als gevolg van schommelingen in de vraag naar het product dat het bedrijf levert, maar ook voor diverse afdelingen binnen een bedrijf onafhankelijk van deze (externe) vraag. Dat laatste is het geval bij éen van de geïnterviewde metalektrobedrijven, waarbij het productieproces van elk product structureel wordt gekenmerkt door wisselingen in het aantal benodigde functies afhankelijk van de fase van het productieproces waarin het product zich bevindt. Het bedrijf heeft met behulp van een functiematrix een inschatting gemaakt van de benodigde functies en hun aantallen en de werknemers vervolgens zelf opgeleid zodat ze inzetbaar zijn op meerdere functies. Door deze aanpak kan het bedrijf het personeel gedurende het hele productieproces optimaal inzetten. Een ander bedrijf in een vergelijkbare situatie heeft dit probleem opgelost door werknemers op vrijwillige basis op te leiden voor een tweede functie.

Hoe staat het momenteel met deze brede inzetbaarheid? Hiertoe kreeg het Werkgeverspanel twee vragen voorgeschoteld: I) in welke mate is er in het bedrijf behoefte aan brede inzetbaarheid van het personeel en 2) in welke mate is het personeel breed inzetbaar als dat van hen gevraagd zou worden. Het verschil tussen de antwoorden op beide vragen is verwerkt in figuur 5.4. Kijkend naar deze figuur valt op dat, ongeacht de beroepscategorie, twee derde van de bedrijven beschikt over personeel dat (meer dan) voldoende breed inzetbaar is om in de behoefte van het bedrijf te voorzien. Bij het niet-technische personeel geldt dit zelfs voor ongeveer 90\%. Echter, bij de uitvoerende technische functies zou een derde graag zien dat deze werknemers breder inzetbaar zijn dan ze nu zijn.

\section{Figuur 5.4}

Verschil tussen behoefte aan en de daadwerkelijke brede inzetbaarheid van personeel, per beroepscategorie (\% bedrijven)

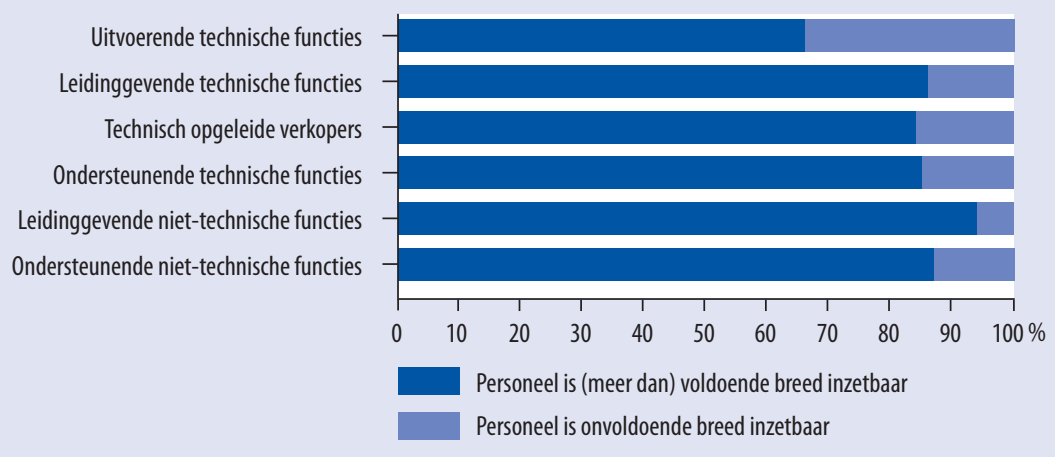

Bron: ROA / Werkgeverspanel Metalektro 2010

Bij de technische verkopers en de ondersteunende technische functies ervaart één op de zes bedrijven een tekort aan brede inzetbaarheid. Aangezien het personeelsbestand van de meeste metalektrobedrijven voor een groot deel uit uitvoerende technici bestaat, valt er aan de brede inzetbaarheid van het personeel in deze beroepscategorie nog het een en ander te ontwikkelen. Voortdurende aandacht voor dit punt lijkt 
dus nodig, ook als wordt gekeken naar de cijfers van voorgaande jaren die hetzelfde beeld laten zien als in figuur 5.4. Het ontwikkelen van de brede inzetbaarheid van het (uitvoerend technisch) personeel lijkt een zaak van de lange adem te zijn.

De behoefte aan breed inzetbare uitvoerende technici komt bij twee derde van de bedrijven voort uit de wens om flexibel om te kunnen gaan met schommelingen in de bedrijfsdrukte. Nogal wat bedrijven in de Metalektro hebben immers te maken met conjuncturele pieken en dalen die elkaar snel kunnen opvolgen. Ook het opvangen van elkaars werk, als mensen afwezig zijn door vakanties, ziekte e.d., creëert bij de helft een behoefte aan personeel dat van meerdere markten thuis is. Op die manier wordt een zekere mate van continuïteit van het werkproces gegarandeerd wat de leveringsbetrouwbaarheid en de kwaliteit van de geleverde producten weer ten goede komt. Het kunnen doen van bepaalde product- en procesinnovaties hangt bovendien ook steeds vaker af van de multi-inzetbaarheid van het personeel: voor de helft van de bedrijven bepalen deze innovaties de behoefte aan brede inzetbaarheid. Andere redenen die genoemd worden, zijn het aantrekkelijker maken van functies en kostenbesparingen. Dat brede inzetbaarheid ervoor kan zorgen dat functies afwisselender worden, zal goed van pas kunnen komen bij het werven van nieuwe medewerkers wanneer de markt weer aantrekt en oudere medewerkers met pensioen gaan (zie ook hoofdstuk 6).

\section{Na de crisis pakt deel bedrijven door met investeringen in brede inzetbaarheid personeel}

De crisis heeft er volgens twee derde van de metalektrobedrijven voor gezorgd dat veel medewerkers breder worden ingezet dan voorheen (Quickscan Maart 2010). Bovendien gaat 45\% haar personeel in de komende jaren functieoverstijgend scholen om op die manier de employability van het personeel te vergroten (Quickscan Mei 2010).

\subsection{Externe samenwerking}

Sociale innovatie beperkt zich niet tot de interne organisatie en het ontwikkelen en benutten van het in de onderneming beschikbare menselijke kapitaal. Bedrijven ontlenen immers hun bestaansrecht aan wat zij voor hun omgeving kunnen betekenen. In deze bedrijfsomgeving bevinden zich de klanten, leveranciers, concurrenten, kennisinstellingen en overheden. Metalektrobedrijven onderhouden allerlei externe relaties die ruimte voor innovatie bieden. Innovaties in deze sfeer hebben vaak betrekking op het creëren of intensiveren van de samenwerking, of het op een andere manier samenwerken dan voorheen. Uit paragraaf 5.I is gebleken dat ongeveer een kwart van de bedrijven in 2010 een externe samenwerking is aangegaan en dat eenzelfde percentage dat van plan is in de komende vijf jaar. Het gaat dan meestal om een bundeling van krachten met een ander bedrijf en in iets mindere mate om samenwerking met een kennisinstelling. 


\section{Figuur 5.5}

Toename uitbesteding van activiteiten in de komende vijf jaar, binnen Nederland en buiten Nederland (\% bedrijven)

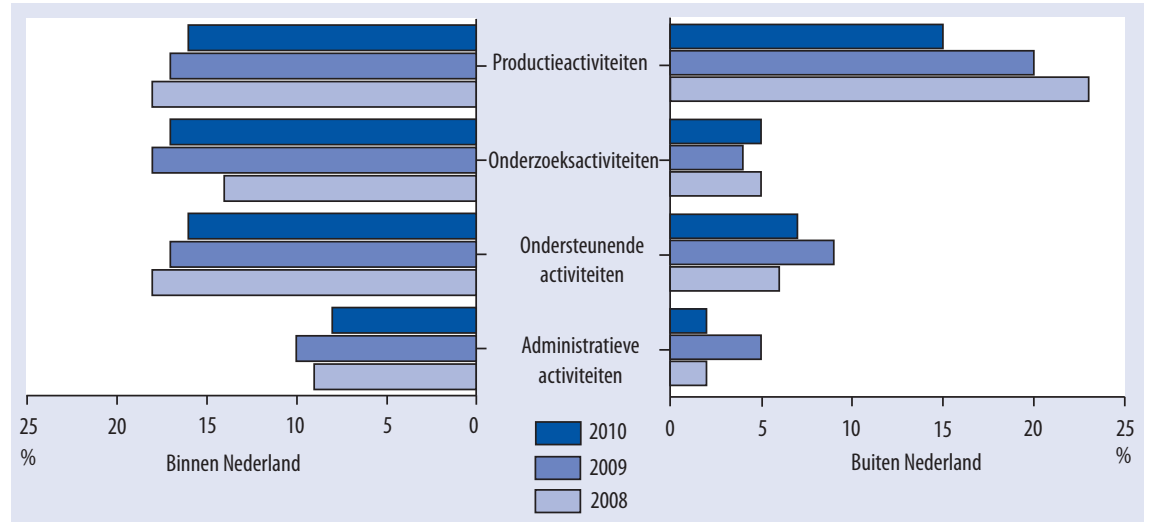

Bron: ROA / Werkgeverspanel Metalektro 2008-2010

\section{Bij uitbesteding kan de kost soms flink voor de baat uitgaan}

Bij het uitbesteden van (een deel van) de productie naar het buitenland zal er soms eerst geïnvesteerd moeten worden, voordat de voordelen ervan benut kunnen worden. Dit ondervond een metalektrobedrijf aan den lijve toen het, vanwege goedkope arbeid en de mogelijkheid om dichter bij de buitenlandse klant te produceren, een deel van de productie overhevelde naar een bestaande buitenlandse productielocatie. Pas nadat de werkprocessen waren gemoderniseerd en het personeelsbestand aldaar werd verkleind, werden de voordelen pas merkbaar. Dit proces heeft een behoorlijke personele inzet ter plaatse gevraagd.

Een mogelijke vorm van samenwerking ontstaat door het uitbesteden van werkzaamheden aan een externe partij. In figuur 5.5 worden de bedrijven weergegeven die in de komende vijf jaar meer activiteiten zullen gaan uitbesteden ten opzichte van het voorgaande jaar, uitgesplitst naar uitbesteding aan bedrijven binnen Nederland (links) en buiten Nederland (rechts). De metalektrobedrijven hebben meer interesse in het uitbesteden van activiteiten in Nederland dan aan in het buitenland gevestigde bedrijven. Ongeveer $15 \%$ verwacht ten opzichte van vorig jaar meer productie-, onderzoeks- en ondersteunende activiteiten in Nederland uit te besteden dan vorig jaar. Deze percentages zijn iets lager dan die in 2009. De samenwerking met buitenlandse bedrijven wordt daarentegen voornamelijk gedomineerd door productieactiviteiten: 15\% verwacht dat in de komende jaren meer te zullen gaan doen. Ook dit percentage ligt lager dan dat van 2009 en dat van 2008. Uitbesteden van ander werk - onderzoek, administratief, of ondersteunend - naar het buitenland staat al enkele jaren op een betrekkelijk laag pitje. 
HOOFDSTUK 5

\section{Uitbesteding en laisser faire gaan niet (altijd) samen}

Wanneer een bedrijf haar producten modulair bouwt, d.w.z. dat het product bestaat uit standaard onderdelen of standaard combinaties van onderdelen die als bouwblokken met elkaar kunnen worden gecombineerd, is het eenvoudiger om de productie van deze modules aan externe partijen uit te besteden en je als bedrijf meer te richten op de productontwikkeling en het productmanagement. Een metalektrobedrijf dat op deze manier werkt, plaatst daarbij wel de kanttekening dat indien de foutmarges klein en de kosten van fouten hoog zijn je als eindverantwoordelijk bedrijf 'bovenop' je onderaannemers moet zitten om te zorgen dat alles goed verloopt. Het verdient vaak ook aanbeveling om de onderaannemers van cruciale onderdelen zo vroeg mogelijk bij het ontwikkelproces van het product te betrekken. 


\section{Vergrijzing}

In dit hoofdstuk wordt ingegaan op de uitstroom van personeel dat met pensioen gaat. We staan stil bij de gevolgen van deze personeelsuitstroom voor de bedrijven in de Metalektro. De uitstroom van werknemers die naar verwachting in de komende vijf jaar met pensioen zullen gaan, wordt in 2010 lager ingeschat dan in 2009. In 2010 varieert deze verwachting van $0,8 \%$ voor niet-technische leidinggevenden tot $5,5 \%$ voor uitvoerende technische functies. Het is opmerkelijk dat de bedrijven weinig problemen verwachten bij de vervanging van werknemers die in de komende vijf jaar met pensioen gaan. Er worden echter wel problemen verwacht voor de uitvoerende technische functies.

Ruim de helft van alle bedrijven neemt maatregelen of zal deze nemen om toekomstige vervangingsproblemen te beperken. Daarbij gaat het zowel om het aantrekken van nieuw personeel (goed opgeleide werknemers of nieuwe werknemers die men zelf verder opleidt), als om het beter inzetbaar maken van het huidige personeel door om-of bijscholing en taakroulatie. Veel HR-maatregelen zijn echter niet specifiek gericht op oudere werknemers. Typische maatregelen die bedrijven vaker aan oudere werknemers aanbieden, zijn het (gedeeltelijk) ander werk laten doen en het inzetten van oudere werknemers op functies waarbij de overdracht van kennis belangrijk is.

\subsection{Uitstroom vanwege pensionering}

De vergrijzing van de bevolking wordt in heel Europa gezien als één van de belangrijkste uitdagingen voor de toekomst. Voor het bedrijfsleven spelen twee belangrijke onderwerpen. Enerzijds de verwachte grote uitstroom van werknemers die met (vervroegd) pensioen gaan. Anderzijds het productief houden van het groeiende aantal oudere werknemers binnen de organisatie, die de financiële druk voelen om later met pensioen te gaan.

Enkele jaren geleden verwachtten veel bedrijven in de Metalektro nog dat een aanzienlijk deel van hun technische werknemers binnen vijf jaar met pensioen zou gaan. In 2009 daalde dit aantal echter ineens aanzienlijk. In de figuren 6.Ia en 6.Ib wordt - per functiecategorie - de ontwikkeling weergegeven van het verwachte percentage werknemers dat binnen vijf jaar met pensioen zal gaan. 


\section{Figuur 6.1a}

Ontwikkeling verwacht aandeel werknemers dat in de komende vijf jaar met pensioen gaat, per functiecategorie

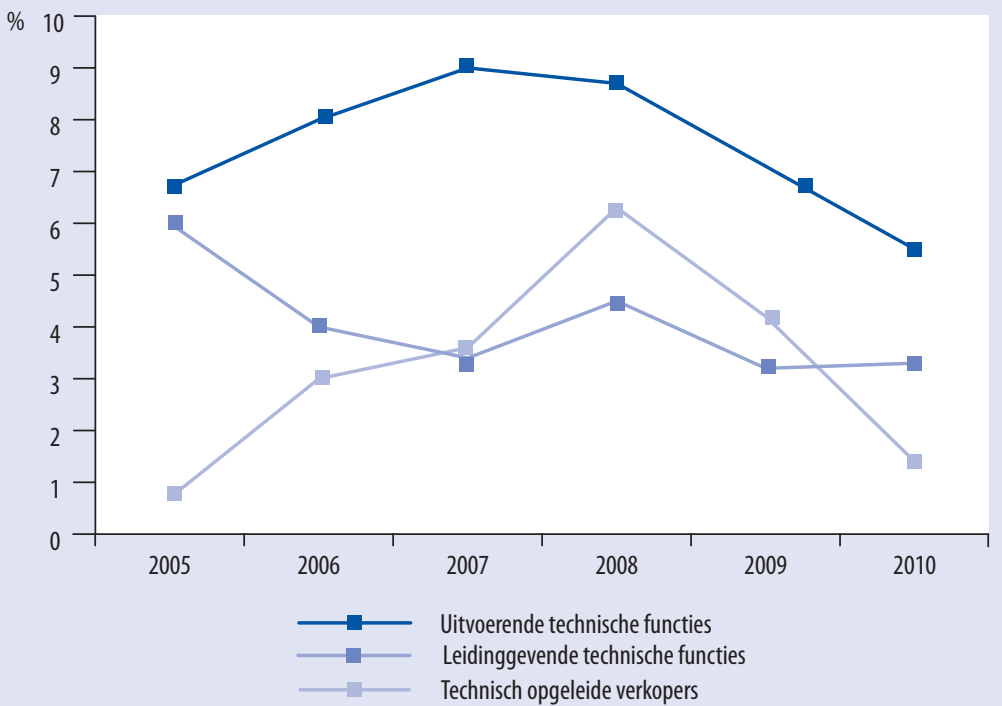

Bron: ROA / Werkgeverspanel Metalektro 2005-2010

De bedrijven in de Metalektro verwachten in 2010 dat 5,5\% van de uitvoerende technische werknemers binnen vijf jaar met pensioen zal gaan. Dit is een beduidend lager percentage dan in 2009. In dat jaar verwachtte men nog dat ruim $7 \%$ van de werknemers in uitvoerende technische functies binnen vijf jaar met pensioen zou gaan. De verwachting over het percentage werknemers dat met pensioen zal gaan, daalt sinds 2007 gestaag. In 2007 dachten de bedrijven nog dat maar liefst $9 \%$ van hun werknemers in de uitvoerende technische functies binnen vijf jaar zou afzwaaien. In 2010 was dit, zoals gezegd, nog maar 5,5\%. Voor de technisch opgeleide verkopers is de verwachte pensioenuitstroom na 2008 gedaald. In 2009 daalde de verwachte pensioenuitstroom al van $6,3 \%$ naar $4,2 \%$. In 20 Io daalde dit verder tot $1,4 \%$. Voor de leidinggevende technische functies is de verwachte pensioenuitstroom daarentegen de afgelopen jaren vrijwel niet veranderd. Zowel in 2010 als in 2009 was deze uitstroom 3,3\%.

\section{Nulurencontract voor gepensioneerden}

Wanneer werknemers de pensioengerechtigde leeftijd hebben bereikt, maar werkgever en werknemer nog geen afscheid van elkaar willen nemen, gaat men soms op basis van een nulurencontract verder met elkaar. Hiervoor blijkt echter binnen de kaders van de geldende CAO's en (overgangs)pensioenregelingen niet altijd ruimte te zijn. 
Figuur 6.1b

Ontwikkeling verwacht aandeel werknemers dat in de komende vijf jaar met pensioen gaat, per functiecategorie

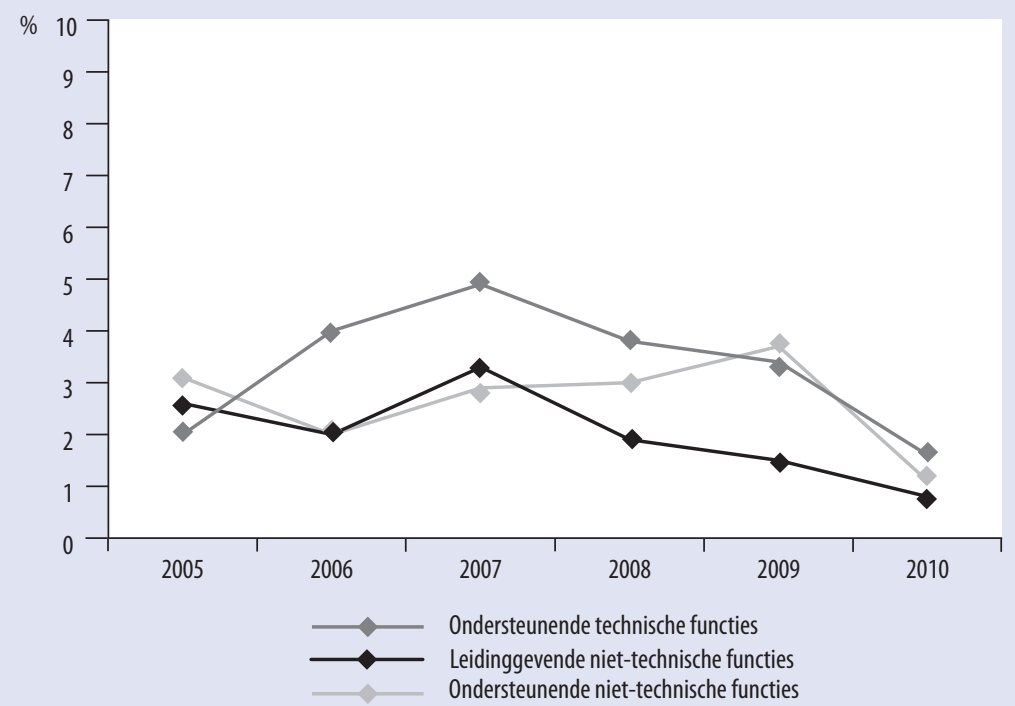

Bron: ROA / Werkgeverspanel Metalektro 2005-2010

In 2009 was de daling van de verwachte pensioenuitstroom onder de werknemers in de ondersteunende technische functies nog gering, maar in 2010 was er sprake van een sterke daling. De verwachte pensioenuitstroom in deze functies halveerde tot $\mathrm{I}, 6 \%$. Ook voor de niet-technische functies is de voor de komende vijf jaar verwachte pensioenuitstroom in 2010 verder afgenomen. Onder de niet-technische leidinggevenden daalde de verwachte pensioenuitstroom van $\mathrm{I}, 5 \%$ tot $0,8 \%$ en onder de ondersteunende niet-technische werknemers van 3,7\% naar I,I\%.

Mogelijk heeft de economische crisis tot een verjonging van het personeelsbestand geleid. De daling van de verwachte pensioenuitstroom bij 5 van de 6 functiecategorieën zou veroorzaakt kunnen zijn doordat bedrijven in de crisis vooral van oudere medewerkers afscheid genomen hebben.

\subsection{Vervangingsproblemen}

We zagen in de figuren 6.Ia en 6.Ib dat de verwachte pensioenuitstroom in 2010 op het laagste niveau ligt sinds de jaren 2005 en 2006 . Verwachten de bedrijven in de Metalektro dan ook minder vervangingsproblemen? In figuur 6.2 wordt stilgestaan bij eventuele verwachte vervangingsproblemen. 


\section{Figuur 6.2}

Verwachte problemen bij het vervangen van werknemers die in de komende vijf jaar met pensioen zullen gaan, per functiecategorie

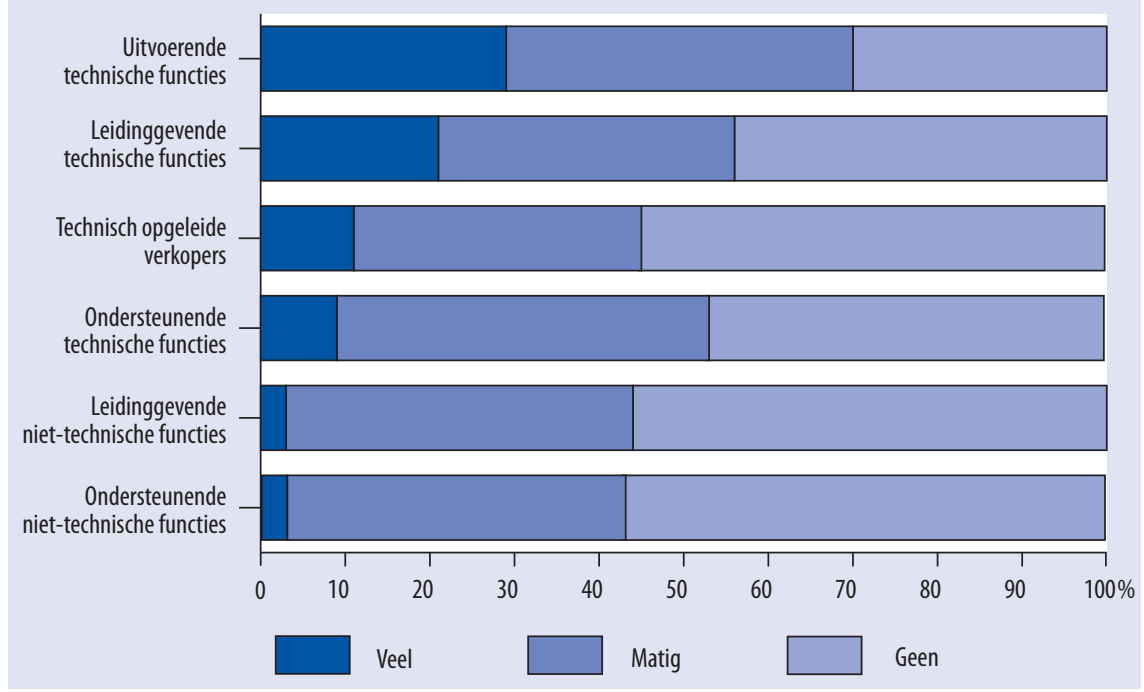

Bron: ROA / Werkgeverspanel Metalektro 2010

Over het algemeen worden er in 2010 door de meeste bedrijven niet veel problemen verwacht bij de vervanging van werknemers die in de komende vijf jaar met pensioen gaan. Op zich is dit natuurlijk niet gek: een lagere pensioenuitstroom leidt tot minder werknemers die vervangen moeten worden, dus tot minder problemen. Bovendien zijn er door de in de economische crisis veelal niet verlengde tijdelijke aanstellingen, meer potentiële werknemers beschikbaar op de arbeidsmarkt. Bij de uitvoerende technische functies verwacht $29 \%$ van de bedrijven echter wel veel vervangingsproblemen, terwijl $42 \%$ weinig problemen verwacht. Slechts $29 \%$ verwacht voor deze functies dus geen vervangingsproblemen.

\section{Proactief opleiden in plaats van reactief reorganiseren}

Lifetime-employment is een gepasseerd station, daarom moeten werkgever en werknemer investeringen doen die de werknemer werkzekerheid geven binnen en buiten het huidige bedrijf. Daarom is het zinvol om te onderzoeken of budgetten, die nu worden besteed aan reorganisaties, naar voren gehaald kunnen worden om als opleidingsbudgetten voor de omscholing van werknemers in te zetten.

Voor de leidinggevende technische functies verwacht $2 \mathrm{I} \%$ van de bedrijven veel vervangingsproblemen en $35 \%$ weinig vervangingsproblemen. Bij het vervangen van technisch opgeleide verkopers geeft slechts II\% aan veel problemen te verwachten, terwijl een derde voor deze functies weinig vervangingsproblemen verwacht. Ook 
voor de ondersteunende technische functies verwacht slechts $9 \%$ veel vervangingsproblemen. Wel verwacht $44 \%$ voor deze functies weinig problemen. Bij de niet-technische functies verwacht slechts $3 \%$ van de bedrijven in de Metalektro veel vervangingsproblemen. Vier op de tien verwachten wel weinig vervangingsproblemen voor de niet-technische leidinggevenden en ondersteunende krachten.

\section{Figuur 6.3}

Ontwikkeling verwachte problemen bij het vervangen van werknemers die in de komende vijf jaar met pensioen zullen gaan: matig of veel problemen (\% bedrijven), 2005-2010

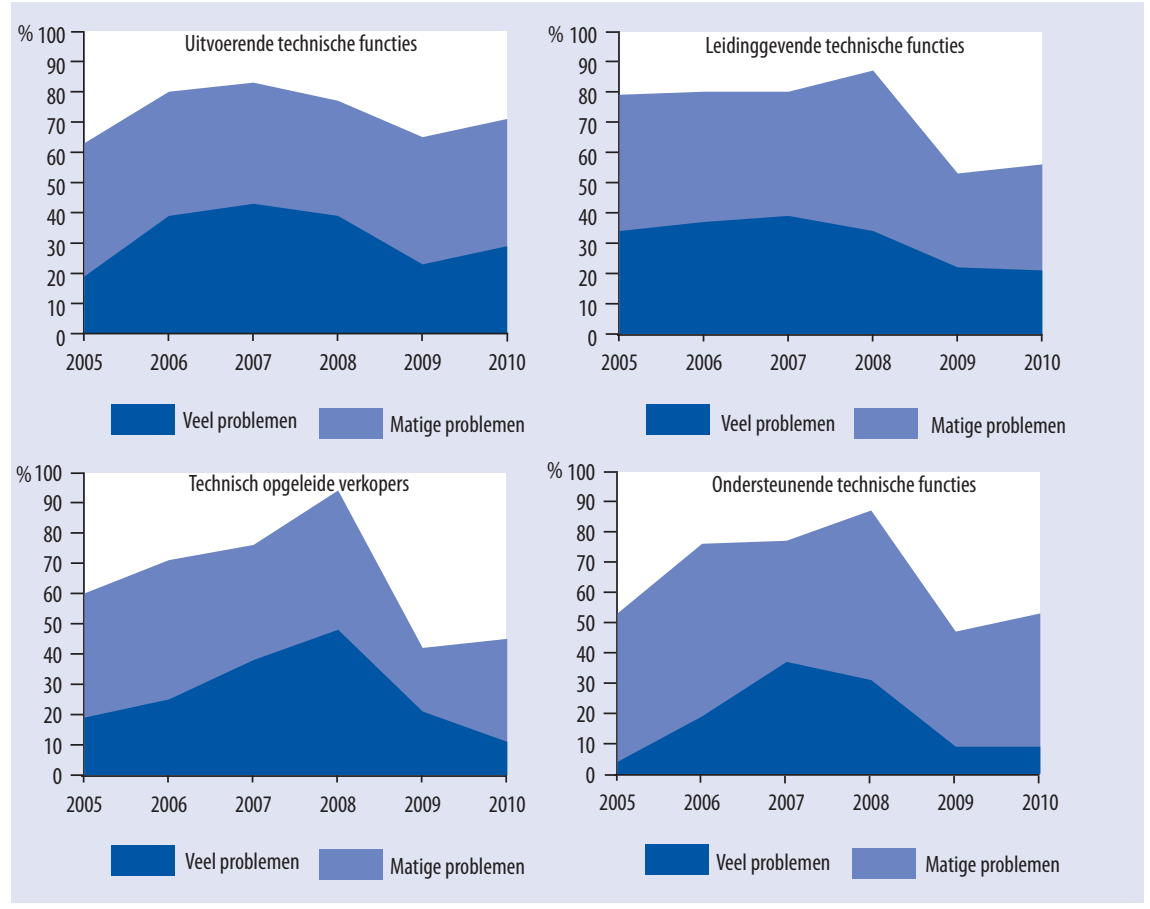

Bron: ROA / Werkgeverspanel Metalektro 2005-2010

Figuur 6.3 geeft een overzicht van de ontwikkeling van de verwachte toekomstige problemen bij het vervangen van werknemers in technische functies voor de jaren 2005-20I0. De figuur laat zien dat de verwachte vervangingsproblemen in 2009 sterk afgenomen zijn. Dit weerspiegelt de daling van de verwachte pensioenuitstroom. In 2010 is er echter geen sprake van een verdere daling in de verwachte vervangingsproblemen. Sterker nog, vooral bij de uitvoerende en ondersteunende technische functies verwachten alweer meer bedrijven vervangingsproblemen dan in 2009. Dit kan al het gevolg zijn van de krappere arbeidsmarkt.

Zo verwacht nu $7 \mathrm{I} \%$ van de bedrijven problemen bij het vervangen van uitvoerende technici, tegenover $65 \%$ in 2009 . Ook bij de ondersteunende technische functies is er 
een toename van het percentage bedrijven dat vervangingsproblemen verwacht van $47 \%$ in 2009 tot $53 \%$ in 2010 . Bij de leidinggevende technische functies en technisch opgeleide verkopers is de stijging in de verwachte vervangingsproblemen echter veel geringer: bij de leidinggevende technici van $53 \%$ naar $56 \%$ van de bedrijven en bij de technisch opgeleide verkopers van $42 \%$ naar $45 \%$.

\section{Verwachte pensioenleeftijd en uittreding}

Men kan zich de vraag stellen in welke mate bovenstaande verwachtingen specifiek gelden voor de Metalektro, of dat ze worden gedeeld door werkgevers in andere sectoren. Er is weinig bestaand vergelijkingsmateriaal. Toch kan uit twee andere databronnen - de DNB Household Survey en het OSA-Arbeidsaanbodpanel - geput worden om deze vraag te beantwoorden.

Aan respondenten van beide panels is gevraagd op welke leeftijd zij denken uit te treden. Aan de hand van het pensioenfonds kan binnen de deelnemers aan het DNB Household Survey een onderscheid worden gemaakt tussen werknemers in technische en niet-technische sectoren. Hieruit blijkt dat de verwachte pensioenleeftijd van werknemers in technische functies niet significant anders is dan in andere sectoren. Dit wordt bevestigd door analyses van het OSA-Arbeidsaanbodpanel, waarmee de verwachte pensioenleeftijd van werknemers in de Metalektro vergeleken kan worden met die van werknemers in andere sectoren.

Echter, doordat de gemiddelde leeftijd van werknemers in de Metalektro hoger is dan in andere sectoren, zal de uitstroom vanwege pensionering in de Metalektro de komende jaren hoger zijn dan in andere sectoren.

Het OSA-Arbeidsaanbodpanel maakt het ook mogelijk om de feitelijke pensioenuitstroom in kaart te brengen. Hieruit blijkt dat ondanks hun gemiddeld genomen hogere leeftijd, de werknemers in de Metalektro de afgelopen jaren niet vaker met pensioen zijn gegaan dan de werknemers in andere sectoren, ook al is het personeelbestand in deze andere sectoren duidelijk jonger.

\subsection{Aanpak vervangingsproblemen}

De uitstroom van werknemers die met pensioen gaan, kan voor bedrijven problemen opleveren als het de productiecapaciteit beperkt, of als het leidt tot verlies van bedrijfsspecifieke kennis en vaardigheden. Daarom mag verwacht worden dat bedrijven zullen proberen deze problemen te voorkomen. Figuur 6.4 geeft een overzicht van de ontwikkeling van het percentage bedrijven dat HR-maatregelen neemt om toekomstige vervangingsproblemen te beperken. Het lijkt erop dat het percentage bedrijven dat HR-maatregelen neemt of gaat nemen ter voorkoming van toekomstige vervangingsproblemen, meebeweegt met de economische conjunctuur. In 2005 en 2006 ondervonden de bedrijven in de Metalektro mogelijk nog de gevolgen van de economische dip aan het begin van de jaren 2000. In 2007 en 2008 was er daarentegen weer sprake van een krappe arbeidsmarkt, waardoor de mogelijke vervangingsproblemen in de nabije toekomst weer reëler werden. In dezelfde periode steeg het percentage bedrijven dat hier aandacht aan besteedde van $60 \%$ naar $73 \%$. Vanaf het begin van de economische crisis in 2008 is deze vervangingsproblematiek veel minder actueel en 
daalde het percentage bedrijven dat HR-maatregelen neemt om toekomstige vervangingsproblemen te beperken tot $56 \%$. In 20 Io is er weer sprake van een lichte toename naar $59 \%$ van de bedrijven. Dit betekent ook dat $4 \mathrm{I} \%$ van de metalektrobedrijven dus geen enkele maatregel neemt om de mogelijke toekomstige vervangingsproblematiek te beperken. Het is opmerkelijk dat het hier niet alleen gaat om bedrijven die weinig problemen verwachten met de vervanging van hun personeel dat de komende jaren met pensioen gaat. Het suggereert dat sommige bedrijven wel matige tot grote vervangingsproblemen verwachten en desondanks nog geen anticiperende HR-maatregelen treffen.

\section{Figuur 6.4}

Ontwikkeling van het aandeel bedrijven dat HR-maatregelen neemt of gaat nemen om toekomstige vervangingsproblemen te beperken (\% bedrijven), 2005-2010

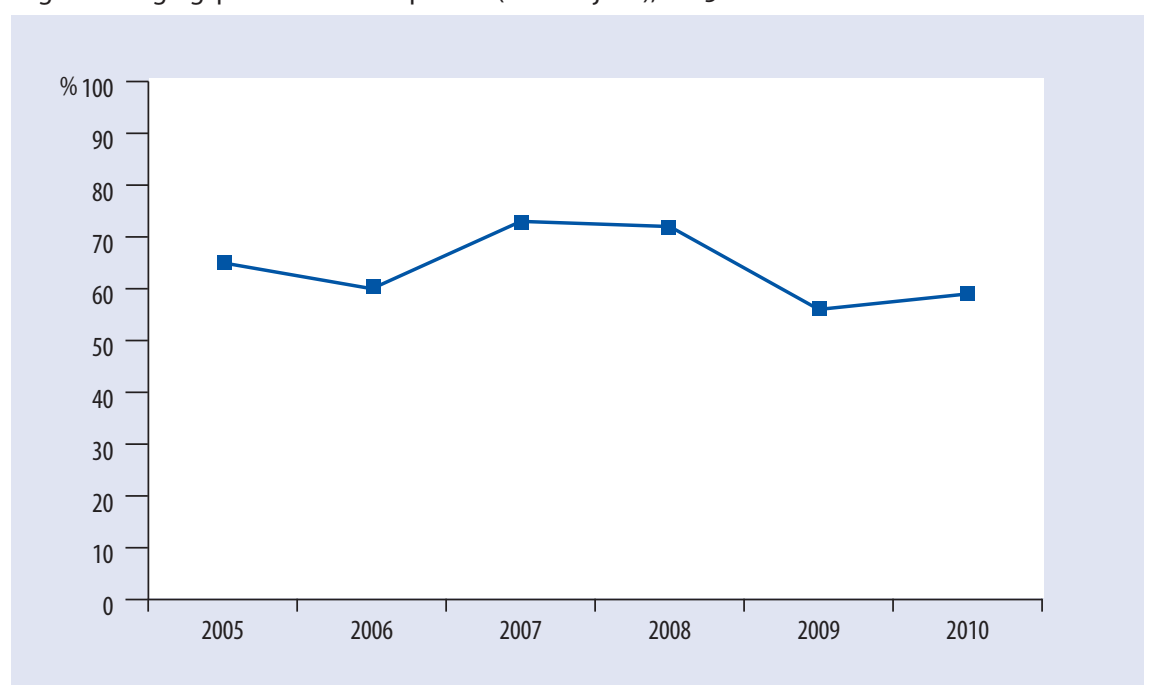

Bron: ROA / Werkgeverspanel Metalektro 2005-2010

Figuur 6.5 laat zien welke HR-maatregelen er worden ingezet of worden overwogen om toekomstige vervangingsproblemen te beperken. De meest genomen maatregel is het aannemen en zelf opleiden van nieuwe werknemers. $74 \%$ van de bedrijven die maatregelen nemen, doen dit al met het oog op de te verwachten vervangingsproblematiek, terwijl I6\% dit in de komende vijf jaar zal gaan doen. Ook proberen bedrijven de toekomstige vervangingsproblemen te beperken door het aannemen van nieuwe, goed opgeleide werknemers. 59\% doet dit momenteel al, terwijl 16\% dit in de komende vijf jaar wil gaan doen. Ook is $57 \%$ van de bedrijven nu reeds bezig met het om- of bijscholen van het huidige personeel. I3\% gaat dit in de komende vijf jaar doen. Daarnaast maakt iets meer dan de helft van de bedrijven zijn werknemers breder inzetbaar door taakroulatie. Nog eens I op de 5 zegt dit in de komende vijf jaar te zullen gaan doen. Een aanzienlijk percentage (42\%) probeert de toekom- 
stige vervangingsproblematiek ook te beperken door het intensiveren van de relaties met het onderwijsveld, terwijl nog eens $13 \%$ dit in de komende vijf jaar gaat doen. Daarnaast neemt 39\% van de bedrijven schoolverlaters aan om de verwachte vervangingsproblematiek te beperken en gaat nog eens $21 \%$ dit binnen vijf jaar doen. Drie andere maatregelen die bedrijven nogal eens noemen zijn: het vergroten van de aantrekkelijkheid van het bedrijf als werkgever ( $28 \%$ nu, I $6 \%$ binnen vijf jaar), het stimuleren van de carrièreplanning van de werknemers ( $25 \%$ nu, $\mathrm{I} 4 \%$ binnen vijf jaar) en het gebruik gaan maken van arbeidsbesparende technologie $(24 \% \mathrm{nu}, \mathrm{I} 5 \%$ binnen vijf jaar).

\section{Figuur 6.5}

HR-maatregelen om toekomstige vervangingsproblemen te beperken (\% bedrijven dat maatregelen neemt)

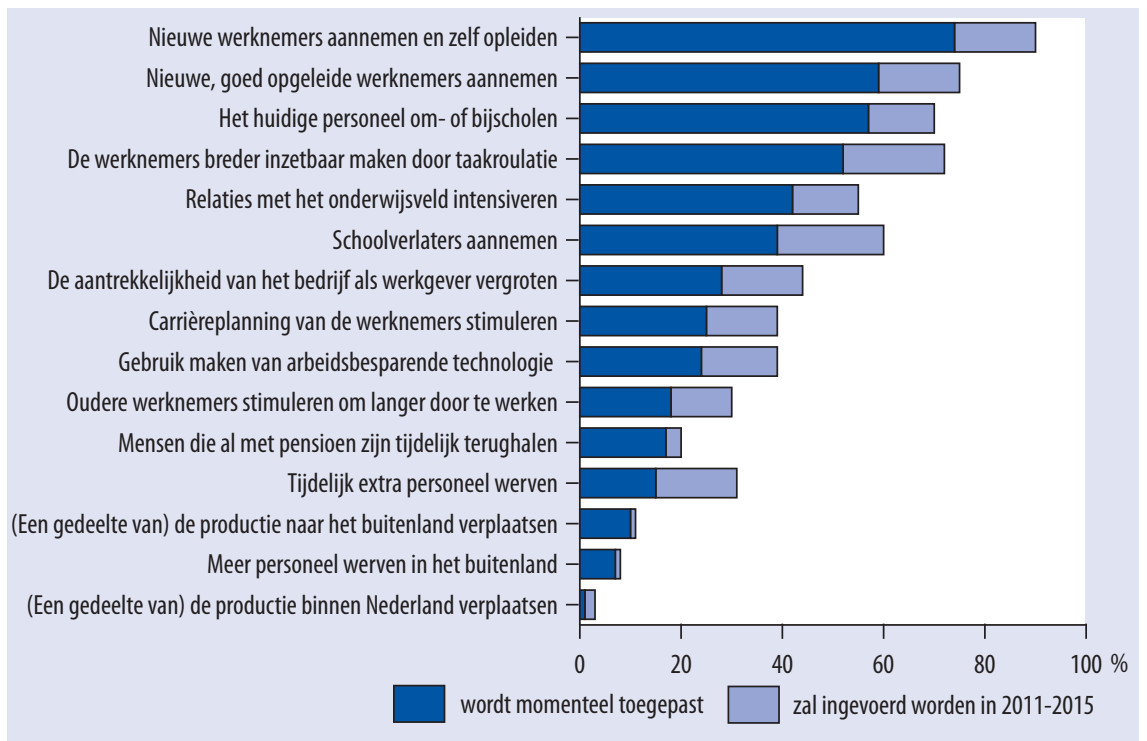

Bron: ROA / Werkgeverspanel Metalektro 2010

Als we deze uitkomsten vergelijken met die in 2009, dan valt het op dat bijna alle HR-maatregelen in 2010 minder vaak worden ingezet dan in 2009. De sterkste afname is te zien bij de maatregelen die de aantrekkelijkheid van het bedrijf als werkgever vergroten, gebruikmaken van arbeidsbesparende technologie, carrièreplanning van de werknemers stimuleren en de relaties met het onderwijsveld intensiveren. Alleen het aannemen en zelf opleiden van nieuwe werknemers werd in 2010 vaker ingezet dan in 2009, terwijl het aantrekken van nieuwe, goed opgeleide werknemers in 2010 even vaak werd ingezet als in 2009 . 


\begin{abstract}
Duurzame inzet van (oudere) werknemers
Om jong en oud duurzaam inzetbaar te houden, zouden bedrijven zich niet meer moeten richten op Employability maar op Enjoyability, dat wil zeggen het plezier in het werk. Dit is namelijk de drijvende kracht achter het aan de slag gaan en blijven van mensen. Enjoyability is ook iets dat zowel belangrijk is voor jongere als voor oudere werknemers. Daarom kan het een rode draad vormen in het personeelsbeleid. Enjoyability kan daarnaast een belangrijke rol gaan spelen bij het binden van werknemers als de arbeidsmarkt weer krapper wordt.

Het creëren van werkomstandigheden zodat oudere (maar in feite alle) werknemers duurzaam aan de slag kunnen blijven, is door een metalektrobedrijf ingevuld door het aanbieden van een aantal faciliteiten aan al haar werknemers: - $\quad$ Overwerk wordt alleen gedaan indien noodzakelijk en overwerk wordt via tijd voor tijd verrekend;

De eerste drie faciliteiten richten zich op het bewaken van de balans tussen de belasting en belastbaarheid van de werknemers. De laatste faciliteit versterkt de sociale cohesie tussen werknemers en geeft tegelijkertijd enige informatie over zaken die spelen in de privésfeer welke van invloed zijn op het functioneren van de werknemer.
\end{abstract}

\title{
6.4 Levensfasebewust personeelsbeleid
}

Bij levensfasebewust personeelsbeleid gaat het om een personeelsbeleid dat afgestemd is op de levensfase waarin de werknemer zich bevindt. Omdat personen in verschillende leeftijden zich in dezelfde levensfase kunnen bevinden, kan dit dus afwijken van leeftijdsbewust personeelsbeleid. Een jonge werknemer met kinderen kan bijvoorbeeld in de zorgfase zitten net als een oudere werknemer die de zorg heeft voor een bepaalde leeftijdsgroep, zoals het geval is bij de laatste fase van het werkende leven die doorgaans samenvalt met een hogere leeftijd. Door het voeren van een levensfasebewust personeelsbeleid gericht op deze laatste fase van het arbeidzame bestaan, kunnen bijvoorbeeld oudere werknemers gestimuleerd worden om langer productief aan het werk te blijven. Hiervoor kunnen HR-instrumenten worden gebruikt die gericht zijn op de ontwikkeling van het menselijk kapitaal van oudere werknemers, alsook om het aanpassen van hun werkomstandigheden. In deze paragraaf staan we stil bij dergelijke HR-instrumenten en aanpassingen van de werkomstandigheden. Uit de cijfers van het Werkgeverspanel Metalektro 2010 blijkt dat slechts $21 \%$ van de bedrijven aangeeft in het HR-beleid speciale aandacht te besteden aan de werknemers van 45 jaar of ouder.

Figuur 6.6 geeft een overzicht van het percentage bedrijven dat gebruik maakt van HR-instrumenten die gericht zijn op de ontwikkeling van van oudere werknemers en aanpassingen van hun werkomstandigheden. Er wordt aangegeven in welke mate het HR-instrument of de werkaanpassing vaker wordt aangeboden aan werknemers die ouder zijn dan 45 jaar dan aan jongere medewerkers. 


\section{Figuur 6.6}

HR-instrumenten en aanpassingen van het werk voor oudere medewerkers (\% bedrijven), 2010

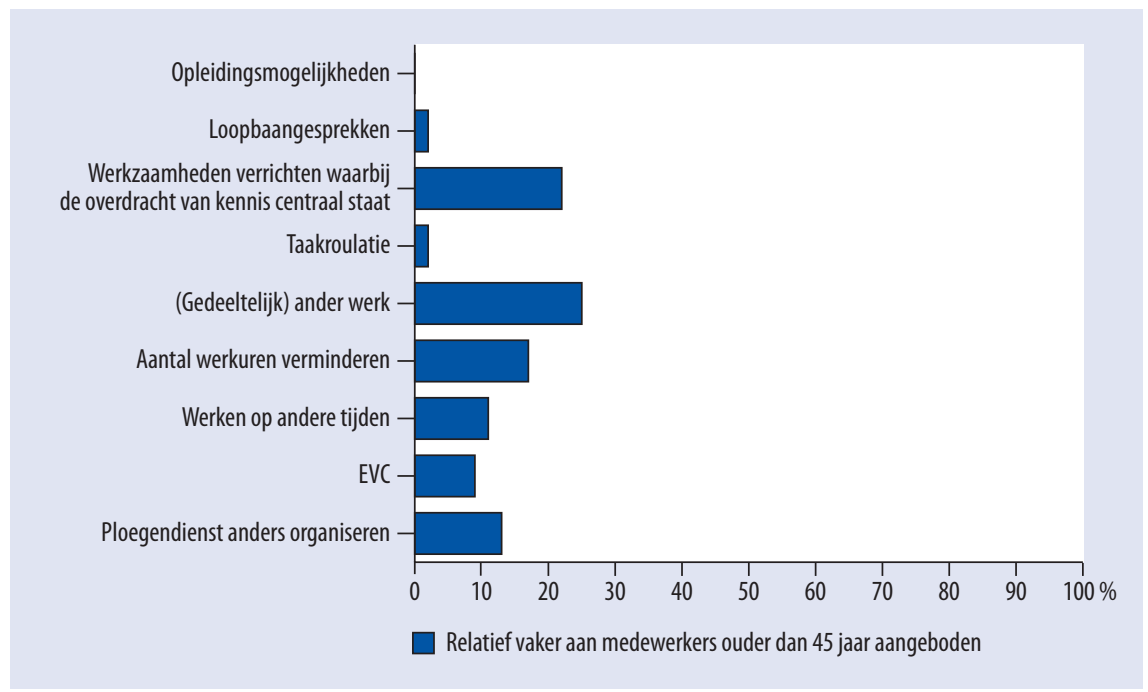

Bron: ROA / Werkgeverspanel Metalektro 2010

De meest gebruikte HR-instrumenten, opleidingsmogelijkheden en loopbaangesprekken, worden niet specifiek ingezet voor oudere werknemers; het gaat overwegend om een generiek HR-beleid. Vanuit het economische perspectief is dit goed te begrijpen: als oudere werknemers aan het einde van hun arbeidsmarktloopbaan komen wordt het voor werkgevers moeilijker om de vaak hoge opleidingsinvesteringen terug te verdienen. Ook loopbaangesprekken worden weliswaar vaak voor alle werknemers ingezet, maar vrijwel nooit specifiek voor oudere werknemers.

\section{Oudere werknemers ander werk aanbieden, hoe doe je dat?}

Een metalektrobedrijf heeft voor een groep oudere werknemers, die niet meer opgeleid konden of wilden worden in de nieuwe productietechnieken, bepaalde werkzaamheden die men voorheen uitbesteedde, teruggehaald naar het bedrijf. Om ervoor te zorgen dat deze nieuwe afdeling zo efficiënt mogelijk kan werken, beschikt deze over de nieuwste installaties. De afdeling heeft geen last van een 'kneusjesimago'. Dit blijkt uit het feit dat werknemers die voelen dat ze het reguliere werk (inclusief ploegendiensten e.d.) niet meer aankunnen, uit zichzelf vragen om naar deze afdeling te worden overgeplaatst. In andere bedrijven vervullen oudere werknemers een belangrijke rol in de kwaliteitsbewaking van de productie. Deze functie heeft veel status en maakt gebruik van de expertise en ervaring van oudere, ervaren werknemers.

Maatregelen die vaak wel specifiek gericht zijn op oudere werknemers hebben betrekking op de werkzaamheden. Daarbij gaat het om het samenstellen van een takenpakket waarin de kennisoverdracht naar jongere medewerkers centraal staat' of de medewerkers '(gedeeltelijk) ander werk' laten doen. Ongeveer een kwart van de bedrijven zet 
deze HR-instrumenten in bij oudere werknemers. Door oudere medewerkers 'werkzaamheden te laten verrichten waarbij de overdracht van kennis centraal staat' zorgen bedrijven er voor dat bepaalde ervaringskennis voor het bedrijf niet verloren gaat. Bij het '(gedeeltelijk) ander werk' laten doen, kan men denken aan het verlichten van de fysieke of mentale arbeidsbelasting. Taakroulatie is echter niet specifiek gericht op oudere werknemers.

Iets meer dan de helft van de bedrijven biedt al hun medewerkers de mogelijkheid aan om minder uren te gaan werken. Bij $17 \%$ is dit beleid vooral gericht op de oudere werknemers. Ook werken op andere tijden wordt in ongeveer de helft van de bedrijven toegepast. Deze maatregel is bij II\% vooral voor 45-plussers. Daarbij zal het bijvoorbeeld gaan om bedrijven waarin oudere medewerkers geen nachtdiensten meer hoeven te draaien. Opmerkelijk is ook dat EVC door $9 \%$ van de bedrijven die hiermee werken vaker wordt ingezet voor oudere werknemers. Ten slotte is het bij I3\% van de bedrijven mogelijk om ploegendiensten voor oudere werknemers anders te organiseren.

\section{Scholing door oudere werknemers}

Figuur 6.6 liet zien dat opleidingsmogelijkheden door bijna alle bedrijven worden ingezet, maar dat de maatregel nooit specifiek gericht is op oudere werknemers. Het probleem voor de werkgever is vaak dat de verwachte opbrengst van een scholingsinvestering kleiner is voor oudere werknemers dan voor jongere werknemers. De periode waarbinnen de investering zou kunnen worden terugverdiend, is immers korter voor werknemers, waarvan verwacht wordt dat zij binnen afzienbare tijd met pensioen zullen gaan. Uit analyses van het OSA-Arbeidsaanbodpanel blijkt dat vergeleken met jongere werknemers, oudere werknemers ( 45 jaar of ouder) in de Metalektro een 12\% lagere kans hebben om aan scholing deel te nemen. Deze lagere kans op trainingsparticipatie is overigens niet typisch voor de Metalektro. In andere sectoren hebben oudere medewerkers gemiddeld eveneens een 12\% lagere kans om aan trainingen deel te nemen. 



\section{De Metalektro in de toekomst}

Om een beeld te kunnen schetsen van de omstandigheden waaronder een metalektrobedrijf de komende jaren zijn personeelsbeleid zal moeten voeren, is het noodzakelijk om inzicht te hebben in de trendmatige veranderingen in de sector. Hiervoor maken wij gebruik van de toekomstverwachtingen op korte termijn, de verwachte veranderingen op opleidingsniveau en de toekomstige speerpunten en knelpunten op HRM-gebied. Daarnaast wordt geput uit landelijke ROA-prognoses van toekomstige knelpunten op de arbeidsmarkt naar opleiding en beroep.

Verwacht mag worden dat de trendmatige ontwikkeling naar hoger opgeleid personeel zich ook de komende jaren zal voortzetten. Omdat de instroom van technisch opgeleid personeel de komende jaren naar verwachting structureel tekort schiet om de vervangingsvraag op te vangen, zal het aantrekken van voldoende goed opgeleide technici waarschijnlijk de belangrijkste uitdaging voor het HR-beleid worden. De tegenvallende arbeidsmarktinstroom van technisch opgeleide schoolverlaters en de desinteresse voor technische beroepen wordt door de metalektrobedrijven als een belangrijke oorzaak gezien voor deze wervingsproblemen.

Bij de toekomstige speerpunten voor het personeelsbeleid blijft het bevorderen van inzetbaarheid van het personeel het meest genoemde punt. Daarbij wordt het steeds belangrijker dat het personeel naast de vereiste vaktechnische competenties ook beschikt over goede gedragsmatige competenties.

\subsection{Arbeidsmarktontwikkeling in de Metalektro op de korte termijn: 2011-2012}

Al langere tijd is er in veel metalektrobedrijven sprake van een trendmatige toename van het vereiste opleidingsniveau van het personeel. In het verleden werd er in deze monitor een onderscheid gemaakt tussen de drie hoofdniveaus: laag, middelbaar en hoog opgeleid. In het Werkgeverspanel Metalektro 2010 is voor het eerst ook het belangrijke onderscheid gemaakt tussen het $\mathrm{MBO}$ I/2 versus het $\mathrm{MBO}_{3} / 4$ niveau.

Hoe belangrijk dit onderscheid is, blijkt uit figuur 7.I. De toename van de werkgelegenheid op $\mathrm{MBO}_{3} / 4$ niveau is duidelijk groter dan die op de lagere $\mathrm{MBO}$-niveaus. Uit de figuur kan geconcludeerd worden dat de werkgelegenheid op LBO-niveau in 
de Metalektro zal afnemen, op $\mathrm{MBO}$ I/2 niveau zal stagneren, terwijl de werkgelegenheid op het hogere $\mathrm{MBO}_{3} / 4$ niveau en op $\mathrm{HBO} / \mathrm{WO}$ niveau zal toenemen.

\section{Figuur 7.1}

Verwachte werkgelegenheidsontwikkeling naar opleidingsniveau in 2011-2012 (\% bedrijven)

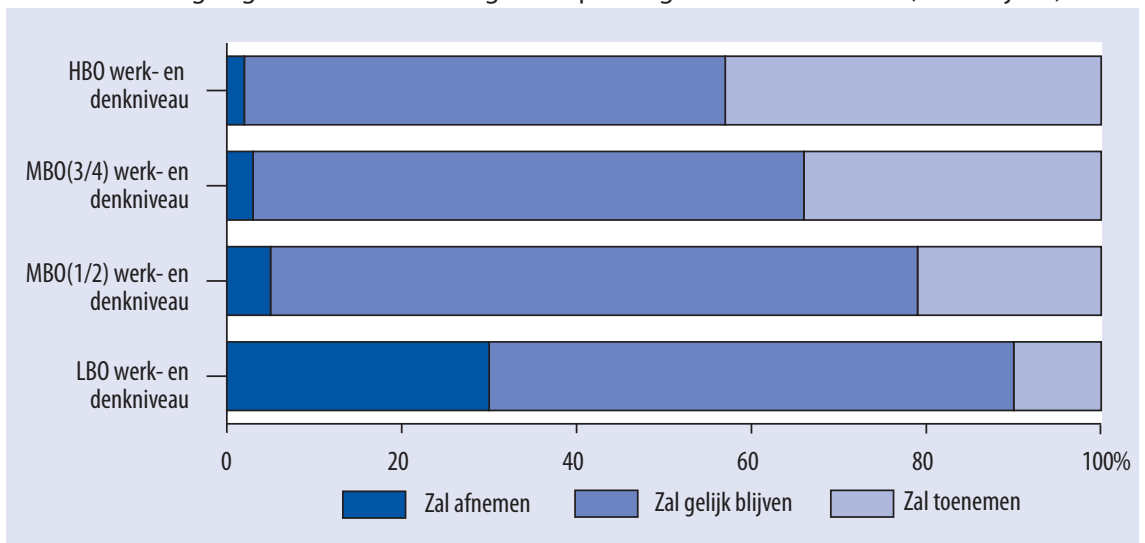

Bron: ROA / Werkgeverspanel Metalektro 2010

Dit bevestigt de eerdere trend van een upgrading van het opleidingsniveau van LBO naar $\mathrm{MBO}$, en van $\mathrm{MBO}$ naar $\mathrm{HBO}$ of WO. De toegevoegde nuance van de verschuiving van $\mathrm{MBO}$ niveau $\mathrm{I} / 2$ naar $\mathrm{MBO}$ niveau 3/4 laat nu beter zien welke upgrading van het opleidingsniveau er gewenst is voor de technische functies.

\section{Leidt de toename van het opleidingsniveau tot een verandering van de arbeidsvoorwaarden?}

De verschuiving van werkgelegenheid van de LBO- en lagere MBO-niveaus naar de hogere MBO- en HBO/WO-niveaus kan ook vragen om andere arbeidsvoorwaarden. Denk hierbij aan zaken als arbeidstijden, thuiswerken, flexibele beloning e.d.

\subsection{Ontwikkelingen op de middellange termijn: 2010-2014}

Volgens de arbeidsmarktprognoses van het Researchcentrum voor Onderwijs en Arbeidsmarkt (ROA) uit 2009 zijn er voor verschillende technische functies in 2014 weer grote knelpunten bij het invullen van vacatures te verwachten. ${ }^{\text {Io }}$ Ondanks de tegenvallende economische situatie ten tijde van het opstellen van deze prognose worden er voor veel technische beroepen tekorten voorspeld. In figuur 7.2 is op een vereenvoudigde manier de verwachte vervangingsvraag ${ }^{\text {II }}$ naar technisch opgeleide

Io. Zie ROA (2009): De arbeidsmarkt naar opleiding en beroep tot 2014, ROA-R-2009/5, hoofdstukken 2 en 3 .

II. De vervangingsvraag betreft alleen de vraag naar nieuwe werknemers ter vervanging van de werknemers die met pensioen zullen gaan. 
werknemers in alle sectoren afgezet tegen de verwachte instroom van technisch opgeleide schoolverlaters. Er is in de figuur geen rekening gehouden met extra vraag naar technisch opgeleiden door een aantrekkende economie. Dit zou nog voor extra vraag naar technisch opgeleid personeel kunnen zorgen. Desalniettemin wordt er voor de gehele Nederlandse economie in totaal een tekort van 60.000 technisch opgeleide werknemers verwacht.

\section{Figuur 7.2}

Verwachte instroom en vervangingsvraag in technische opleidingen 2010-2014 (in aantallen werknemers)

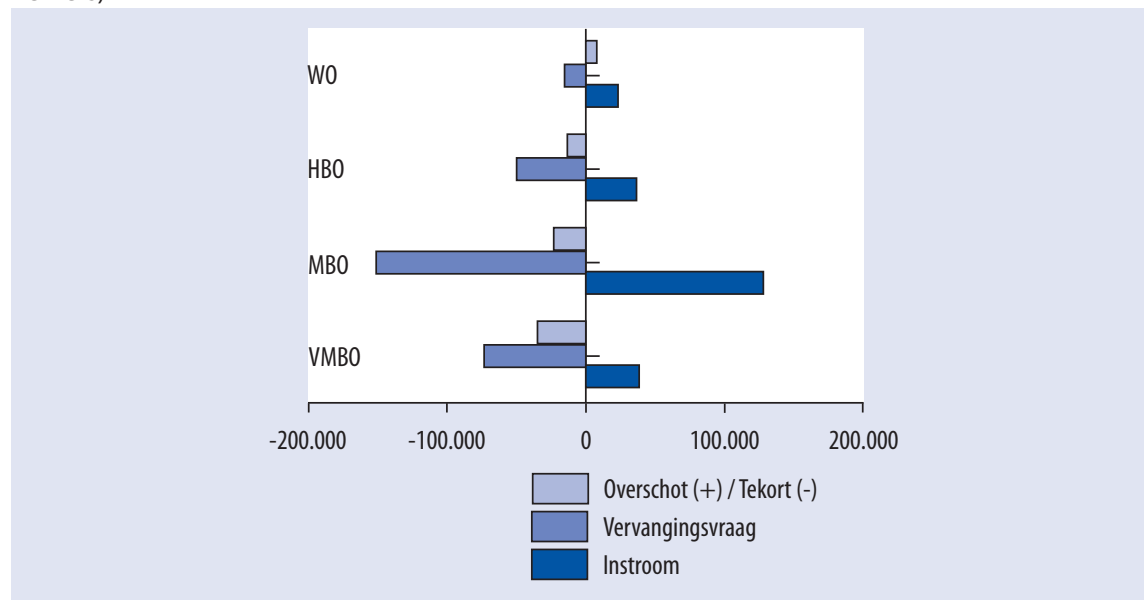

Bron: ROA, Prognose arbeidsmarkt naar opleiding en beroep 2010-2014; zie "De arbeidsmarkt voor bètatechnici", PlatformPocket 23, Platform Bètatechniek, Mei 2010. Instroom is afgeleid uit Tabel 5.

De grootste tekorten worden op MBO-niveau verwacht, maar ook op VMBO-niveau wordt er een flink personeelstekort verwacht. Kleinere tekorten worden er voorspeld voor technisch personeel op HBO-niveau. Alleen op universitair niveau is er volgens de ROA-prognoses geen sprake van personeelstekorten. In hoeverre het lichte aanbodoverschot van technisch personeel op WO-niveau daadwerkelijk zal optreden, hangt echter af van de vraag hoe snel bedrijven er voor zullen kiezen om meer mensen op dit niveau aan te trekken en van de snelheid waarmee de economie de komende jaren aantrekt.

\section{If you don't have to beat them, join them!}

Om de instroom van jongeren te vergroten, heeft een aantal bedrijven een pool opgezet waarin jongeren worden aangenomen die een opleiding starten (in een competence center en met behulp van een e-portfolio) in combinatie met afwisselend werken bij de deelnemende bedrijven. Het is de bedoeling dat de jongere aan het eind van het traject bij één van de deelnemende bedrijven in dienst komt. 


\section{Toekomstige problemen bij het vinden van technisch personeel}

Figuur 7.3 geeft een overzicht van de ontwikkeling van het percentage bedrijven dat bepaalde problemen bij het werven van technisch personeel verwacht. Meer dan de helft van de bedrijven gaf in 2010 aan dat ze voor de komende vijf jaar een te geringe instroom vanuit de opleidingen verwacht. Dat is echter veel minder dan de ruim $60 \%$ die dit de afgelopen jaren als punt van zorg voor de toekomst aangaf. Bijna een derde van de bedrijven verwacht dat er de komende jaren te weinig sollicitanten op hun vacatures afkomen, terwijl ongeveer de helft vreest dat de sollicitanten de komende jaren niet de juiste competenties hebben. Dit beeld verschilt niet veel van dat in de voorgaande jaren.

\section{Figuur 7.3}

Verwachte problemen bij het vinden van technisch personeel in de komende 5 jaar (\% bedrijven)

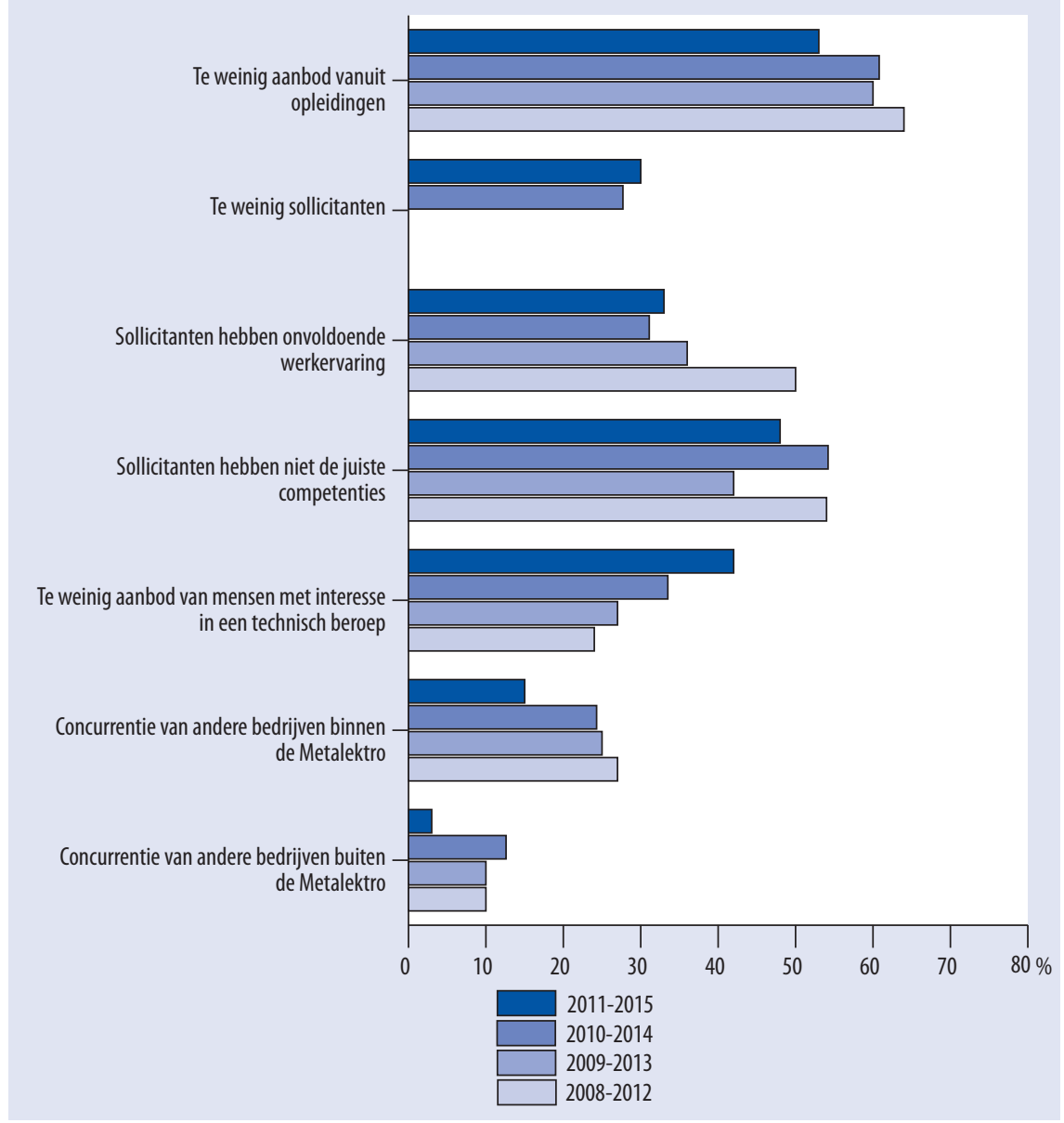

Bron: ROA / Werkgeverspanel Metalektro 2007-2010 
Daarentegen was er een duidelijke stijging van het percentage bedrijven dat verwacht dat er de komende jaren te weinig aanbod is van mensen met interesse voor een technisch beroep. In 2010 noemde $42 \%$ van de bedrijven dit als een verwacht knelpunt bij het vinden van technisch personeel. Dat is bijna twee keer zoveel als in 2008 . In 20 Io was er echter veel minder vrees voor de concurrentie op de arbeidsmarkt van bedrijven binnen ( $15 \%)$ of buiten $(3 \%)$ de Metalektro dan in voorgaande jaren.

Het beeld dat hieruit naar voren komt, pleit derhalve voor een gezamenlijke aanpak van de toekomstige wervingsproblemen. Het is immers niet de arbeidsmarktconcurrentie van andere bedrijven die voor problemen zorgt, maar het tekortschieten van de arbeidsmarktinstroom vanuit de opleidingen en het gebrek aan interesse in technische beroepen.

\section{Nood breekt wet: inzet van uitzendmedewerkers en meerdere tijdelijke contracten}

Eén van de redenen waarom verschillende bedrijven geen gebruik maken van flexibele arbeid (met name uitzendmedewerkers) is de lange inwerktijd die nodig is voordat werknemers volledig inzetbaar zijn. Een metalektrobedrijf dat onlangs onverwacht met een sterke toename van de afzet werd geconfronteerd, heeft echter toch enkele uitzendmedewerkers in de productie ingezet, wat goed is bevallen. Door de onzekerheid over de duur van deze vraagtoename (tijdelijke opleving of structureel), wijkt het bedrijf af van het normale aannamebeleid waarin werknemers met een jaarcontract bij goed functioneren een vaste aanstelling krijgen. In plaats daarvan wordt nu ook vaker een tweede jaarcontract aangeboden.

\subsection{Verandering in de technische functies op de middellange termijn: 2011-2015}

De verwachte veranderingen in de technische functies zijn onder andere van belang voor het bepalen van de competenties waarover zowel het technisch personeel dat reeds in de Metalektro werkzaam is (zie hoofdstuk 4), als de technici die de komende jaren in de sector instromen moeten beschikken. De verwachte veranderingen in de technische functies zijn daardoor ook van groot belang voor het beroepsonderwijs. In paragraaf 4.I zijn de verwachte veranderingen op de korte termijn (binnen een jaar) besproken. In deze paragraaf richten we ons op de middellange termijn.

\section{Als het trucje niet te leren valt, selecteer dan de persoon die het trucje al kent}

Een metalektrobedrijf geeft aan dat ze er op let dat de medewerkers die zij aantrekken bepaalde kenmerken hebben. Het bedrijf is er namelijk van overtuigd dat deze kenmerken al in iemand aanwezig moeten zijn, omdat deze niet aangeleerd kunnen worden. Het gaat dan bijvoorbeeld om zaken als affiniteit met techniek, teamspeler, communicatief sterk en hulpvaardig zijn. Affiniteit met techniek kan onder andere worden vastgesteld door te vragen wat een kandidaat in zijn/haar vrije tijd doet. Denk hierbij aan het sleutelen aan een auto of brommer. 
Figuur 7.4 vergelijkt de op de middellange termijn verwachte functieveranderingen in 2010 met die van de afgelopen jaren. De figuur laat zien dat de toekomstverwachtingen van de metalektrobedrijven op dit punt de laatste jaren vrij stabiel zijn. De meeste verwachte veranderingen in de technische functies worden door vrijwel evenveel bedrijven genoemd als in voorgaande jaren. Dit is ook niet zo verwonderlijk aangezien de inhoud van functies vooral verandert door technologische en sociale innovaties, die vaak sterk padafhankelijk zijn. Zoals in de hoofdstukken I en 5 reeds werd besproken, blijven veel metalektrobedrijven nieuwe innovaties doorvoeren en zullen ze dat ook op de middellange termijn blijven doen.

\section{Figuur 7.4}

Verwachte veranderingen in functies van het technisch personeel in de komende 5 jaar $(\%$ bedrijven)

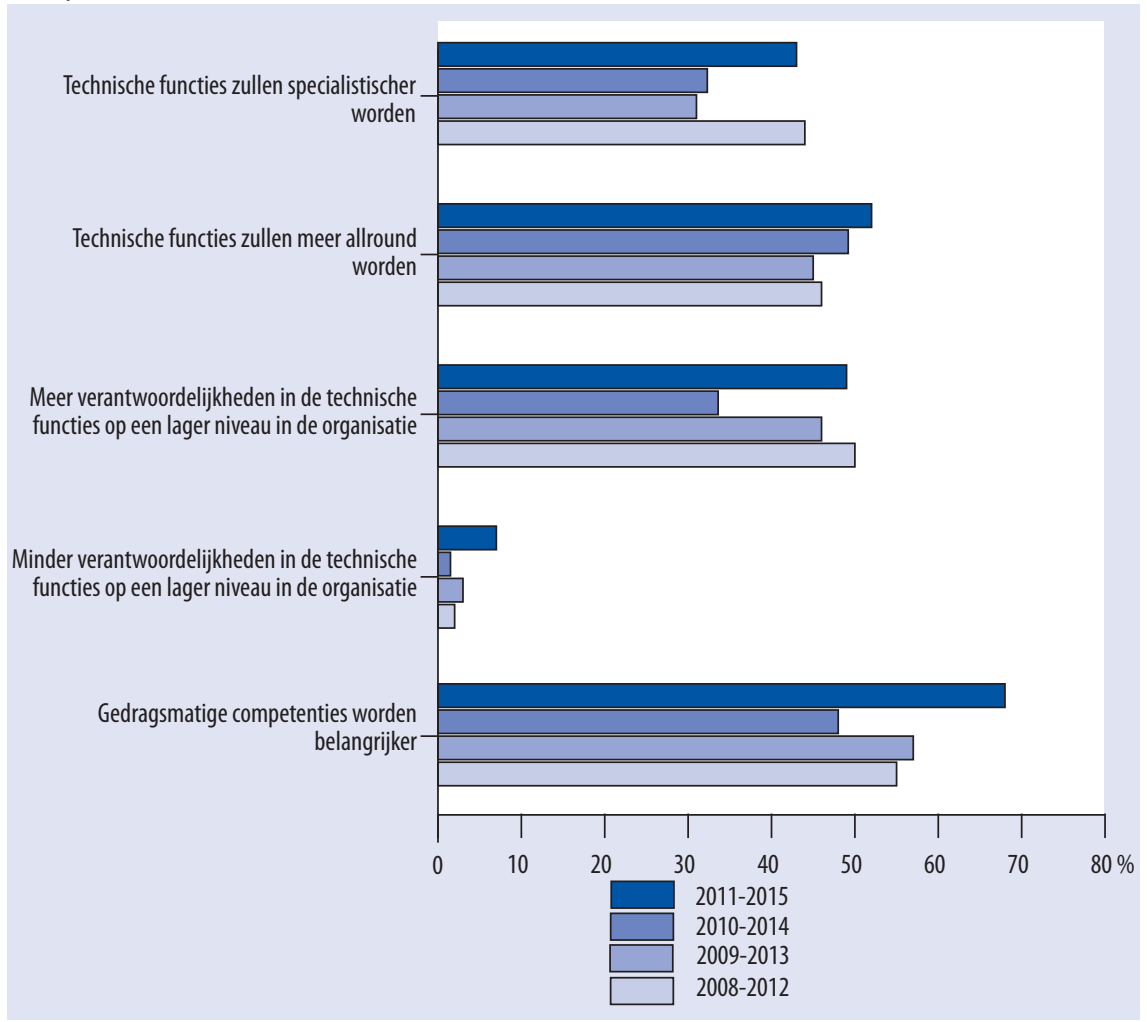

Bron: ROA / Werkgeverspanel Metalektro 2007-2010

Figuur 7.4 laat zien dat de vaakst genoemde veranderingen betrekking hebben op het meer allround worden van de technische functies en het belangrijker worden van de gedragsmatige 'PROFI'-competenties. Deze verbreding van de werkzaamheden in veel technische functies past in de veranderde structuur van veel bedrijven. Aan de andere kant verwacht $43 \%$ van de bedrijven dat technische functies in hun bedrijf juist 
specialistischer zullen worden. Deze bijna paradoxale beweging naar meer allround functies, terwijl tegelijkertijd óók het belang van specialistische functies toeneemt, is al enkele jaren gaande. Door de technische ontwikkeling en de mede daaraan gerelateerde organisatorische veranderingen ontstaan er meer en meer specialistische functies, terwijl de organisatie van het werk en de noodzaak tot samenwerking het tegelijkertijd steeds belangrijker maken dat het technisch personeel ook allround is. Soms heeft deze spagaat zelfs betrekking op een en dezelfde functie, maar dan voor de verschillende taken die iemand in deze functie moet uitvoeren.

\section{Het creëren van een optimale functie-inhoud}

Bij het samenstellen van iemands functie is het van belang dat de taken, verantwoordelijkheden en bevoegdheden bij elkaar passen. Maar zeker zo belangrijk is dat de betreffende medewerker voor deze bevoegdheden ook het draagvlak krijgt van de leidinggevenden en collega's. Idealiter is de functie ook afgestemd op wat de werknemer leuk vindt en waar hij of zij goed in is. Dit laatste kan bij (nieuwe) medewerkers onder andere achterhaald worden door te informeren naar de activiteiten die zij in hun vrije tijd ondernemen (vrijwilligerswerk, hobbies).

\subsection{HR-beleid op de middellange termijn: 2011-2015}

\section{Speerpunten}

Het is opmerkelijk dat de metalektrobedrijven in 20 Io veel minder vaak duidelijke speerpunten voor hun personeelsbeleid hebben dan in de afgelopen jaren. Dit suggereert dat veel bedrijven nu ze zich net lijken te herstellen van de economische crisis, vooralsnog eerst op dit punt pas op de plaats willen maken. Verreweg het belangrijkste speerpunt voor het personeelsbeleid van de metalektrobedrijven in de komende 5 jaar, is het bevorderen van de duurzame inzetbaarheid van het huidige personeel. In figuur 7.5 is te zien dat dit zowel voor, als tijdens en na de crisis voor de meeste bedrijven het belangrijkste speerpunt is. Daarnaast is er in het HR-beleid veel aandacht voor het verminderen van het verzuim en het bevorderen van coachend leiderschap. Deze drie speerpunten kwamen in de laatste vier jaren altijd ergens in de top vijf van de belangrijkste HR-speerpunten voor. Meestal waren zij zelfs de drie belangrijkste speerpunten.

Maar er treden ook verschuivingen op. Nieuw zijn in 2010 de nummers vier en vijf van de vaakst genoemde HR-speerpunten: levensfasebewust personeelsbeleid en het betrekken van het personeel bij het beleid van de organisatie. Dit wil echter niet zeggen dat de aandacht voor deze twee speerpunten in 2010 is gegroeid. Integendeel, ook hier zien we een terugval in het aantal bedrijven dat deze speerpunten voor hun personeelsbeleid heeft. Bij de meeste andere HR-speerpunten is de terugval echter veel groter. Dit geldt met name voor het intensiveren van de samenwerking met de onderwijsinstellingen, het stimuleren van cursusdeelname en het loopbaanbeleid. 


\section{Figuur 7.5}

Speerpunten personeelsbeleid voor de komende 5 jaar (\% bedrijven)

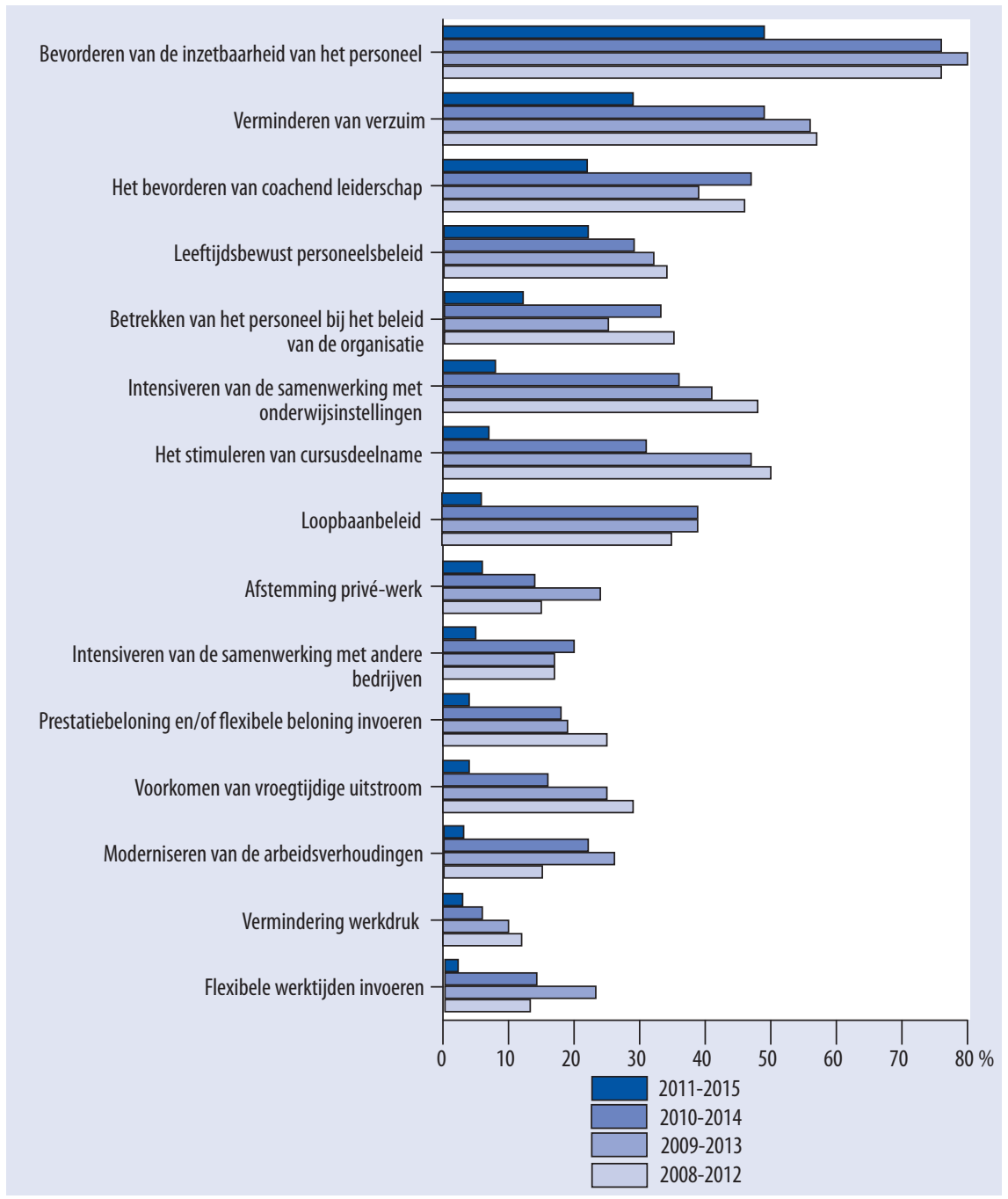

Bron: ROA / Werkgeverspanel Metalektro 2007-2010

Het intensiveren van de samenwerking met de onderwijsinstellingen, ooit één van de belangrijke speerpunten, werd in 2010 nog maar nauwelijks als speerpunt van het toekomstig personeelsbeleid genoemd. Hetzelfde geldt voor het loopbaanbeleid en het stimuleren van cursusdeelname. Het is niet waarschijnlijk dat dit geen belangrijke speerpunten meer vormen, omdat de doelen al bereikt zijn. 


\section{Stimuleren van gedragsmatige competenties via de beoordelingssystematiek}

De aspecten van het werk waarop werknemers beoordeeld worden, hebben vanzelfsprekend invloed op hun gedrag. Door in de beoordelingssystematiek naast de resultaten ook de manier waarop deze resultaten bereikt zijn mee te wegen, worden iemands gedragscomponenten in zijn of haar beoordeling meegenomen. Op deze manier worden werknemers gestimuleerd om hun gedragsmatige competenties te ontwikkelen.

\section{Instrumenten}

Om de beoogde speerpunten voor het personeelsbeleid om te zetten in daadwerkelijk beleid hebben de metalektrobedrijven een heel scala aan instrumenten ter beschikking. Functioneringsgesprekken, beoordelingsgesprekken, scholings- en ontwikkelingsgesprekken, werkoverleg en opleidingsfaciliteiten worden al door het overgrote deel van de bedrijven gebruikt (zie hoofdstuk 4). Figuur 7.6 laat zien dat dit voor veel bedrijven ook de komende jaren de belangrijkste HR-instrumenten zijn. Bovendien zijn er bedrijven die deze instrumenten nog niet gebruiken, maar dat in de toekomst wel willen gaan doen. Veel aandacht gaat er de komende jaren ook uit naar HR-instrumenten die gericht zijn op een planmatige ontwikkeling van het personeel, zoals functieroulatie, loopbaanplanning, bedrijfs- en persoonlijke opleidingsplannen en competentiemanagement.

\section{Figuur 7.6}

HR-instrumenten voor de komende 5 jaar (\% bedrijven)

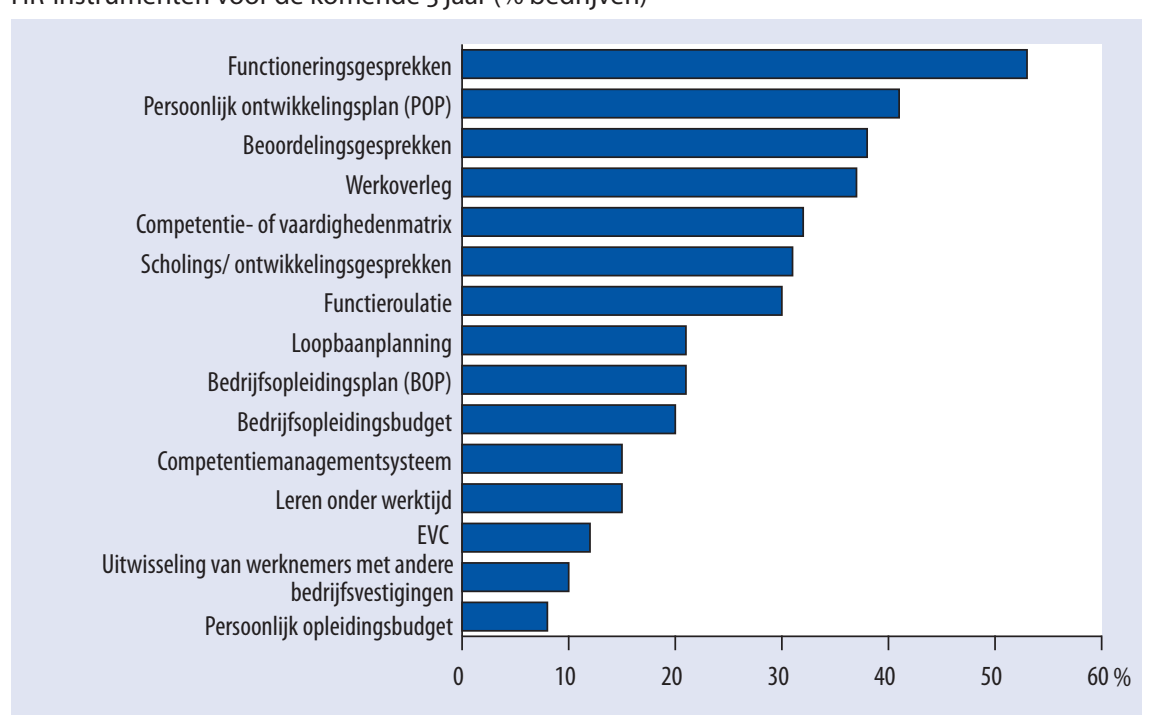

Bron: ROA / Werkgeverspanel Metalektro 2010 


\section{Belonen naar prestatie: van weerstand naar motivatie}

Het invoeren van belonen naar prestatie kan nogal eens op weerstand stuiten, zo merkte een metalektrobedrijf. Na veelvuldig uitleggen waarom belonen naar prestatie werd ingevoerd en ook hoe dergelijke beloningen (bonus, e.d.) toegekend zouden worden, verdween deze weerstand beetje bij beetje en maakte de weerstand plaats voor de vraag "En wat moet ik doen om zo'n bonus te verdienen?".

\section{Knelpunten}

Iets meer dan een kwart van de bedrijven verwacht de komende jaren geen knelpunten bij het realiseren van hun HR-speerpunten (zie figuur 7.7). Dat betekent echter ook dat driekwart wel één of meer knelpunten moet zien te overwinnen om de speerpunten voor hun personeelbeleid te kunnen realiseren. Een derde denkt dat de realisatie van de speerpunten van het HR-beleid zou kunnen stranden op personeel dat moeite heeft met de beoogde veranderingen.

\section{Figuur 7.7}

Knelpunten bij het realiseren van toekomstige speerpunten van het HR-beleid, 2009-2010 (\% bedrijven)

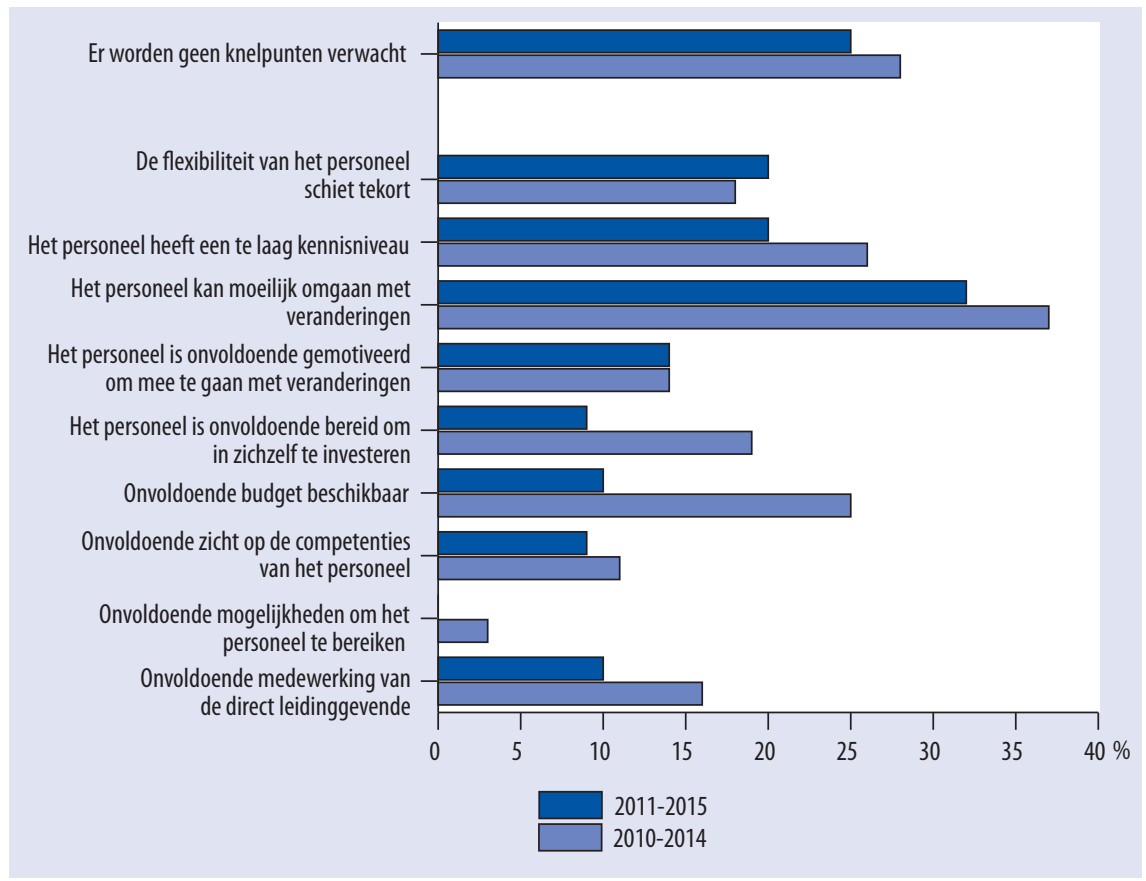

Bron: ROA / Werkgeverspanel Metalektro 2009-2010 
Andere vaakgenoemde struikelblokken voor een succesvolle invoering van nieuwe HR-instrumenten zijn een te laag kennisniveau bij het personeel (20\%), of het niet flexibel genoeg zijn van het personeel (20\%). Inflexibel personeel was ook de afgelopen jaren één van de grote struikelblokken voor het vernieuwen van het HR-beleid. In 2008 verwachtte nog $3 \mathrm{I} \%$ van de bedrijven dat de flexibiliteit van hun personeel tekort zou schieten, om de speerpunten van hun HR-beleid te kunnen realiseren. In 2009, op het dieptepunt van de crisis, was dat echter nog slechts bij I $8 \%$ het geval. Dit zou er op kunnen wijzen dat de economische crisis in 2009 het personeel heeft doen beseffen dat het voor het handhaven van de concurrentiepositie van het bedrijf, noodzakelijk is om open te staan voor veranderingen in de organisatie en het vergroten van hun inzetbaarheid.

\section{Jonge werknemers die zich 'oud' voelen}

Bedrijven lopen soms tegen het probleem aan dat werknemers vanaf 35-40 jaar zich al te oud vinden om nog aanvullende scholing te gaan volgen. Het gaat dan om LBO- en MBO-opgeleiden die vaak voor hun twintigste al met werken begonnen zijn. Zij zijn voor hun gevoel al in geen eeuwigheid meer naar school geweest en zien dit ook niet meer zitten. Een manier om deze medewerkers te motiveren om zich toch verder te bekwamen, is om hen heel duidelijk te maken dat er voor hen geen plaats meer zal zijn in het bedrijf wanneer zij zich niet verder ontwikkelen. Wanneer er, zoals in veel metalektrobedrijven het geval is, nieuwe technieken worden geïntroduceerd waardoor oude kennis onbruikbaar wordt, is dit ook onvermijdelijk.

Ook bij andere personeelsgerelateerde factoren zien we een afname van het aantal bedrijven dat deze als een mogelijk struikelblok voor het realiseren van hun HR-speerpunten noemt. Weliswaar voorziet een aantal bedrijven nog steeds dat toekomstige veranderingen in het personeelsbeleid stuk zouden kunnen lopen op personeel dat niet in zichzelf wil investeren (9\%), maar dit is in veel minder bedrijven het geval dan in 2009 .

Ook door de bedrijven zijn er de nodige aanpassingen gedaan om het doorzetten van de speerpunten te vereenvoudigen. Zo wordt 'onvoldoende budget' (IO\%) minder vaak als struikelblok genoemd dan in de afgelopen jaren. Ook is de medewerking van direct leidinggevenden flink verbeterd ten opzichte van 2009. In 2010 gaf IO\% van de bedrijven dit als struikelblok op, terwijl dit in 2009 nog door $16 \%$ genoemd werd. Ook het zicht op de competenties van het personeel blijkt iets verbeterd. Het werd in 20IO door slechts $9 \%$ als mogelijk knelpunt genoemd. 
HOOFDSTUK 7

\section{Meer efficiënte inzet van personeel door interne personeelspool}

Eén van de metalektrobedrijven had haar werknemers in groepen geplaatst en aan een vaste voorman toegewezen. Wanneer er even geen werk was voor met name de best functionerende werknemers uit de groep, gaven de voormannen dit niet aan omdat ze deze goede werknemers niet af wilden staan. Dit leidde tot een inefficiënte inzet van personeel. $0 \mathrm{~m}$ deze inefficiëntie tegen te gaan, zijn alle productiemedewerkers in het bedrijf nu in een personeelspool geplaatst van waaruit ze per project worden toegewezen aan de voormannen. 


\section{Agenda voor de toekomst}

In dit hoofdstuk worden de belangrijkste ontwikkelingen in de metalektrosector in vogelvlucht besproken en zien we wat deze ontwikkelingen betekenen voor het beleid van de bedrijven. Er wordt achtereenvolgens ingegaan op het economische herstel na de crisis, technologische en sociale innovatie, de voortschrijdende upgrading van het gevraagde competentieniveau en de vraag naar PROFI-competenties, het opleidingsen ontwikkelingsbeleid, de vervangingsproblematiek, levensfasebewust personeelsbeleid, personeelswerving, de speerpunten van het toekomstig personeelsbeleid en de verspreiding van good practices en HR tools. Daarna presenteren we een vernieuwde Agenda voor de Toekomst. Deze agenda biedt metalektrobedrijven handreikingen om de komende jaren de effectiviteit van hun arbeidsmarkt- en personeelsontwikkelingsbeleid te vergroten.

\subsection{Ontwikkelingen en trends}

\section{Herstel Metalektro na de crisis}

De Nederlandse economie herstelde in 20 Io langzaam maar zeker. In de Metalektro leidde dit tot meer bedrijvigheid, meer werkgelegenheid en een toename van het aantal vacatures. In vrijwel alle functies is het percentage bedrijven met een krimpende werkgelegenheid gedaald. Het werkgelegenheidsherstel is het sterkst in de uitvoerende technische functies. De werkgelegenheidsgroei in de Metalektro wordt vooral gedragen door de middelgrote tot grote bedrijven. Daarbij hebben vooral de bedrijven in de sectoren Machinebouw, Transportmiddelen en Elektrotechniek weer meer personeel gekregen.

\section{Technologische en Sociale Innovatie}

De innovatiekracht van de metalektrosector blijft hoog, ook al liep het aantal gerealiseerde innovaties in 2010 enigszins terug ten opzichte van de voorgaande jaren. $80 \%$ van de bedrijven gaf aan in 20 Io één of meer technologische innovaties te hebben doorgevoerd. Ze hebben zich vooral gericht op het verbeteren van bestaande producten en het verbeteren van productieprocessen. Voor $201 \mathrm{I}$ verwachten de bedrijven weer op het hoge niveau van de jaren ervoor te innoveren. Dit lijkt echter geen structu- 
rele ontwikkeling te zijn: voor de komende vijf jaar wordt er namelijk een terugval verwacht van het aantal technische innovaties.

Ook werden er in 2010 in de Metalektro minder sociale innovaties geïntroduceerd dan in de voorgaande jaren. Veel bedrijven lijken op dit punt enigszins pas op de plaats te maken, want ook de komende jaren verwachten minder bedrijven sociale innovaties door te voeren. De bedrijven hebben op het terrein van sociale innovatie echter nog wel dezelfde voorkeuren als voorheen: het variabel inzetten van technici, projectmatig werken en samenwerken met een ander bedrijf.

\section{Voortschrijdende upgrading van PROFI-competenties en brede inzetbaarheid}

De technologische en de daaraan gerelateerde sociale innovaties leiden in veel bedrijven tot een upgrading van de vereiste competenties van het personeel. De groeiende vraag naar allround technici die zelfstandig kunnen werken, komt vooral voort uit de concurrentie die de bedrijven op hun afzetmarkt ondervinden. Om een hoge kwaliteit van de producten te kunnen realiseren en goed in te kunnen spelen op specifieke wensen van klanten moet het technisch personeel naast de noodzakelijke vaktechnische competenties ook over gedragsmatige competenties beschikken. Deze zijn in de vorige edities van de Arbeidsmarktmonitor Metalektro bestempeld als de PROFI-agenda. Deze PROFI-agenda richt zich op de volgende competenties:

- Probleemoplossend vermogen

- Relatie met klanten

- Omgaan met veranderingen

- Flexibiliteit

- Initiatief

Bedrijven verwachten dat hun personeel in de toekomst steeds vaker bovenstaande competenties moet bezitten, met de nadruk op probleemoplossend vermogen en flexibiliteit. Bovendien is het erg belangrijk dat medewerkers goed kunnen samenwerken en waar nodig kennis willen delen, zowel binnen hun team als tussen afdelingen.

De behoefte aan werknemers die beschikken over de genoemde PROFI-competenties vloeit ook voort uit de behoefte aan breed inzetbaar personeel. Eén derde van de bedrijven zou graag zien dat hun personeel dat werkzaam is in de uitvoerende technische functies breder inzetbaar wordt dan nu het geval is. Het is wat dat betreft ook opmerkelijk dat een kwart zowel behoefte heeft aan technisch specialisten als aan technische allrounders. Dit illustreert de noodzaak binnen de metalektrobedrijven aan mensen die beschikken over hoogwaardige vakkennis, maar ook breed inzetbaar zijn.

De competentiebehoeften van de bedrijven in de Metalektro wordt weerspiegeld in de aansluiting tussen onderwijs en arbeidsmarkt. Vier van de vijf recent ingestroomde schoolverlaters met een $\mathrm{MBO}$ - of HBO-diploma op zak, vindt dat hun functie redelijk tot goed aansluit op de opleiding. MBO-schoolverlaters geven aan dat ze in hun 
functie vooral vakkennis en probleemoplossend vermogen nodig hebben, terwijl schrijven, spreken en vreemde talen minder van hen gevraagd worden. HBO'ers kunnen naar eigen zeggen prima voldoen aan de behoefte aan competenties rond het leren van nieuwe dingen, samenwerken, ICT en discussiëren. Maar hun vakkennis, besluitvaardigheid en vermogen om duidelijk te communiceren moet volgens eigen zeggen nog worden verbeterd.

\section{Opleidingsbeleid en interne mobiliteit}

De vereiste upgrading van het personeel en de toenemende vraag naar technici die onder andere beschikken over de genoemde PROFI-competenties, vergen aanzienlijke investeringen in trainingen en opleidingen. De uitgaven voor scholing en opleiding als percentage van de loonsom lagen in 2010 echter op een lager niveau dan in 2009 . Het zijn vooral de hoge scholingskosten, als ook de verloren werktijd, die bedrijven ervan weerhouden om meer medewerkers te laten scholen.

$\mathrm{Al}$ met al volgden in $201057 \%$ van de vaste werknemers, $24 \%$ van de tijdelijke werknemers en Io\% van de uitzendkrachten één of meer trainingen of cursussen. Deze scholing is overigens nog steeds hoofdzakelijk gericht op vakkennis, al neemt de aandacht voor gedragsmatige competenties iets toe. De scholing gericht op vaktechnische kennis en vaardigheden illustreert het grote belang dat veel bedrijven hechten aan het up-to-date houden van de competenties van hun technisch personeel.

Naast het volgen van cursussen en trainingen is het informeel leren op de werkvloer ook van groot belang voor het ontwikkelen van de benodigde competenties. Daarom is het een goede zaak dat in veel bedrijven het bevorderen van coachend leiderschap gezien wordt als een speerpunt van het personeelsbeleid voor de komende jaren. Coachend leiderschap versterkt het informeel leren op het werk en is bij uitstek geschikt om de vereiste PROFI-competenties bij het personeel te ontwikkelen. Naast coachend leiderschap kan informeel leren ook zeer goed worden bevorderd door het vergroten van de interne mobiliteit. In 2010 was deze interne mobiliteit binnen de metalektrobedrijven weer aanzienlijk hoger dan in het crisisjaar 2009. Ruim de helft gaf aan dat er personeel binnen het bedrijf van functie is veranderd. Deze mobiliteit heeft iets vaker een horizontaal dan een verticaal karakter door onvoldoende hogere functies en het kennisniveau bij het personeel. Juist deze horizontale mobiliteit is echter cruciaal voor het breder inzetbaar maken van het personeel.

\section{Vervangingsproblematiek en levensfasebewust personeelsbeleid}

Om ook in de toekomst aan de vraag naar personeel met de juiste competenties te kunnen voldoen, is het belangrijk om de oudere werknemers zo lang mogelijk goed inzetbaar te houden. De gemiddelde leeftijd van de werkenden in de Metalektro is met $4 \mathrm{I}, \mathrm{I}$ jaar namelijk hoog en loopt voorlopig alleen maar op. De branche met gemiddeld de oudste werknemers is de Basismetaal (43,7 jaar). Meer dan één derde 
van de werknemers in deze branche is ouder dan 50 jaar. De 'jongste' branche is de Metaalproductensector (gemiddeld 40,5 jaar). Hier zijn slechts twee van de tien werknemers de 50 al gepasseerd. Door de toenemende vergrijzing komt voor steeds meer werknemers het pensioen in zicht. Deze pensionering brengt met zich mee dat een deel van de opgebouwde expertise en bedrijfsspecifieke kennis verloren kan gaan, wat verstrekkende gevolgen kan hebben voor bedrijven in de Metalektro.

Het aantal bedrijven dat problemen verwacht bij het vervangen van het technisch personeel dat de komende jaren met pensioen gaat, was in 2010 weer groter dan in het crisisjaar 2009. De meeste problemen worden verwacht voor de uitvoerende technische functies: $71 \%$ van de bedrijven verwacht problemen bij het vervangen het personeel in deze functies, tegenover $65 \%$ in 2009 . De vervanging van ondersteunende krachten wordt door de metalektrobedrijven als minst problematisch gezien. Het aantal werknemers dat in de komende vijf jaar met pensioen zal gaan, wordt anno 2010 overigens lager geschat dan in 2009 . Het varieert in 2010 van $0,8 \%$ voor niettechnische leidinggevenden tot $5,5 \%$ voor uitvoerende technische functies.

Door de vergrijzing en de komende krapte op de arbeidsmarkt moet er meer aandacht komen voor de duurzame inzetbaarheid van medewerkers. Daarbij zal er veel aandacht moeten uitgaan naar de oudere medewerkers, waardoor deze langer productief inzetbaar blijven en ook langer willen blijven werken. Een goed levensfasebewust personeelsbeleid kan oudere werknemers stimuleren om langer te blijven doorwerken en hun competenties op peil te houden. In de metalektrobedrijven zijn de meeste HR-instrumenten echter niet specifiek gericht op oudere werknemers. Wel biedt $25 \%$ van de bedrijven oudere medewerkers (gedeeltelijk) ander werk aan en ook worden oudere werknemers ingezet op functies waarin zij hun ervaringskennis kunnen doorgeven.

\section{Werving personeel}

Bedrijven zullen ook meer aandacht moeten gaan besteden aan de werving van nieuw personeel. Door het weer aantrekken van de afzet, de bovengenoemde vervangingsproblematiek en de stagnerende instroom van schoolverlaters uit het technisch onderwijs, zal de arbeidsmarkt voor technisch opgeleiden de komende jaren veel krapper worden. De in de tweede helft van 2010 oplopende tijd dat vacatures open staan, vormt reeds een eerste indicatie van het krapper worden van de arbeidsmarkt. De toenemende krapte op de arbeidsmarkt leidde in 2010 al tot meer wervingsproblemen. Daarbij waren de problemen het grootst bij het invullen van vacatures voor uitvoerende technische functies. Volgens $62 \%$ van de bedrijven beschikken de sollicitanten niet over de voor deze functies vereiste competenties. Door deze wervingsproblemen neemt de werkdruk toe en blijft er werk liggen of worden bepaalde deadlines niet gehaald.

Bedrijven in de Metalektro vinden, net als in voorgaande jaren, dat het inschakelen van uitzendbureaus het meest effectief is om aan uitvoerend en ondersteunend tech- 
nisch personeel te komen. Wanneer bedrijven leidinggevend technisch personeel of technisch opgeleide verkopers nodig hebben, schakelen ze het liefst een commercieel werving- en selectiebureau in. Het bieden van goede loopbaanperspectieven is ook een effectief middel om de wervingsproblemen voor technisch personeel te verminderen. Het overgrote deel van de bedrijven dat met wervingsproblemen te kampen heeft, vangt deze problemen op door het personeel dat men in dienst heeft flexibel in te zetten. Hoewel de economie in 2010 net weer uit het dal omhoog kruipt, is het opmerkelijk dat $\mathrm{I} 4 \%$ van de bedrijven genoodzaakt is om toch de productie te beperken doordat er te weinig geschikt personeel voor handen is.

\section{Speerpunten toekomstig personeelsbeleid}

Ook de komende jaren blijft het bevorderen van de inzetbaarheid van het huidige personeel het belangrijkste speerpunt voor het personeelsbeleid. Daarnaast zijn het verminderen van het verzuim, het bevorderen van coachend leiderschap en een levensfasebewust personeelsbeleid belangrijke speerpunten voor het HRM-beleid. Het ontwikkelen van coachend leiderschap is belangrijk om het proces van 'boeien en binden' te versterken. Ook krijgt het voeren van een levensfasebewust personeelsbeleid steeds meer aandacht van veel bedrijven als structurele oplossing om hun personeel in alle levensfases optimaal in te kunnen zetten.

Het is opmerkelijk dat het intensiveren van de samenwerking met de onderwijsinstellingen in 2010 minder vaak als belangrijk speerpunt van het toekomstig personeelsbeleid wordt genoemd. Hetzelfde geldt voor het loopbaanbeleid en het stimuleren van cursusdeelname. Het is niet waarschijnlijk dat dit geen belangrijke aandachtspunten meer zijn, omdat de doelen al bereikt zijn. Veeleer zal er sprake zijn van enige terughoudendheid met de verdere uitbouw van deze HR-instrumenten vanwege de huidige onzekerheid over de snelheid en de mate waarin de economie zich de komende tijd zal herstellen.

\section{Verspreiding good practices en HR-tools}

Kleinere en middelgrote bedrijven blijken vaak onvoldoende mogelijkheden te hebben om hun personeelsontwikkelings- en arbeidsmarktbeleid op eigen kracht verder te ontwikkelen. Regionale samenwerking met andere bedrijven kan hier een oplossing bieden. Dit is zeker het geval wanneer kleinere bedrijven onvoldoende informatie hebben over de mogelijkheden tot en de voor- en nadelen van verschillende sociale innovaties. Daarbij gaat het ook om de overdracht van "good practices": het identificeren van initiatieven op het vlak van het arbeidsmarkt- en personeelsbeleid die bij andere bedrijven hun effectiviteit hebben bewezen.

De overdracht van good practices kan ertoe bijdragen dat niet ieder bedrijf zelf op zoek hoeft te gaan naar de wijze waarop bepaalde vormen van sociale innovatie ontwikkeld en geïmplementeerd kunnen worden. Daarbij is het van groot belang dat de inzichten 
die verkregen zijn uit de good practices vertaald worden in een aantal toegankelijke, gemakkelijk hanteerbare en direct implementeerbare tools.

\subsection{Agenda voor de Toekomst}

Wat betekenen de ontwikkelingen in de Metalektro voor het beleid dat de bedrijven de komende jaren moeten gaan voeren? We vatten de belangrijkste punten samen in de Agenda voor de Toekomst. Vanzelfsprekend bouwt deze Agenda voor de Toekomst voort op de in de vorige edities van de Arbeidsmarktmonitor geformuleerde aandachtspunten.

\section{Lange-termijnstrategie personeelsbehoefte}

Bedrijven zullen moeten proberen om hun HR-beleid in te bedden in een langetermijnstrategie voor het invullen van hun personeelsbehoefte. Startpunt van deze strategie is het zo goed mogelijk in kaart brengen van de verwachte personeelsbehoefte - in kwaliteit en kwantiteit - voor de komende jaren. Daarbij is het ook belangrijk om een goed beeld te krijgen van de in de komende jaren te verwachten vervangingsvraag vanwege de uitstroom van oudere medewerkers die met pensioen gaan. Dit kan ook een belangrijke leidraad bieden voor het opleidings-, ontwikkelings- en wervingsbeleid van de metalektrobedrijven in de komende jaren.

Daarom zal vanuit deze lange-termijnstrategie moeten worden bezien in hoeverre de hieronder genoemde actiepunten binnen het bedrijf meer of minder accent moeten krijgen.

\section{Opleidings- en ontwikkelingsbeleid}

Voor een goed opleidings- en ontwikkelingsbeleid is het in kaart brengen van de competenties van het zittend personeel van belang. Daarnaast is een goede inschatting van het verwachte competentieniveau van de beoogde instroom van toekomstige werknemers wenselijk. Dit vraagt een structureel opleidings- en ontwikkelingsbeleid dat toegespitst is op de bedrijfsspecifieke behoefte.

Naast het investeren in vaktechnische vaardigheden en de inspanningen om de upgradingsdoelstellingen te realiseren, moet door de metalektrobedrijven ook worden ingespeeld op de toenemende vraag naar allround vakmensen die verantwoordelijkheid kunnen dragen voor de invulling van hun eigen werkzaamheden. Werknemers moeten voorbereid worden op toekomstige sociale innovaties, zodat deze een goede kans van slagen hebben. Deze sociale innovaties zullen vaak betrekking hebben op het variabel inzetten van technici, projectmatig werken en het samenwerken met andere bedrijven. Dit vereist een toenemende aandacht voor de vijf essentiële gedragsmatige competenties, die we kunnen aanduiden als de PROFI-agenda:

- Probleemoplossend vermogen

- Relatie met klanten 
- Omgaan met veranderingen

- Flexibiliteit

- Initiatief

Metalektrobedrijven moeten daarom in hun opleidings- en ontwikkelingsbeleid veel aandacht schenken aan het versterken van de PROFI-competenties van hun technisch personeel. Dit kan door formele scholing en door gestructureerd gebruik te maken van informeel leren op de werkvloer. De effectiviteit van informeel leren kan worden versterkt door coachend leiderschap, waarbij de medewerkers zowel positieve als kritische feedback krijgen op de wijze waarop zij hun werkzaamheden uitvoeren.

\section{Loopbaanmanagement}

Het HR-beleid van de metalektrobedrijven moet zich meer gaan richten op het stimuleren van verschillende vormen van interne mobiliteit, niet alleen vanwege de innovatiedynamiek en de behoefte aan flexibel, breed inzetbaar personeel, maar ook om het personeel aantrekkelijke loopbanen te kunnen bieden en ongewenst verloop te voorkomen. Door het creëren van functies waarin werknemers verschillende aan elkaar gerelateerde taken vanuit een eigen verantwoordelijkheid uitvoeren, ontstaat er hoogwaardige werkgelegenheid die medewerkers boeit en bindt. Dit zal ook de aantrekkingskracht van de sector op de arbeidsmarkt vergroten. Daarbij kan coachend leiderschap de loopbaanperspectieven van het personeel versterken.

\section{Sociale innovatie}

Net zoals de technologische innovatie voor de concurrentiepositie van het bedrijf noodzakelijke vernieuwing van producten en processen voortbrengt, zo zijn ook sociale innovaties steeds bepalender geworden voor het concurrentievermogen van bedrijven. Dit vereist dat bedrijven het innovatievermogen van het HRM-beleid vergroten binnen de grenzen van de mogelijkheden die het bedrijf hiervoor heeft. Om dit te realiseren, moeten bedrijven zich niet richten op het simpelweg kopiëren van populaire 'best practices', maar meer aandacht geven aan Research \& Development $(\mathrm{R} \& \mathrm{D})$ met betrekking tot sociale innovatie, op soortgelijke wijze als ze dat doen bij technologische innovaties. Communicatie en het betrekken van het personeel bij het innovatieproces is cruciaal. Alle stappen ontwikkeling, implementatie én evaluatie moeten hierbij de nodige aandacht krijgen. Ook is op dit punt het verbeteren van de samenwerking met kennisinstellingen gewenst.

\section{Duurzame inzetbaarheid}

De verdere ontwikkeling van duurzaam personeelsbeleid is gericht op vier cruciale elementen:

- Een pro-actief levensfasebewust personeelsbeleid voor alle werknemers.

- Investeren in de competentieontwikkeling van het oudere personeel door scholing, functieroulatie en informeel leren. 
- Het faciliteren van de doorstroom van fysiek of mentaal zware functies naar andere, minder belastende functies binnen of buiten het eigen bedrijf.

- Het stimuleren van mobiliteit in de laatste loopbaanfase en het ontwikkelen van flexibele uittredemogelijkheden die aansluiten bij de behoeften van het bedrijf en de medewerkers.

\section{Wervingsbeleid}

De in 2010 aantrekkende vraag naar personeel laat zien dat het niet lang meer hoeft te duren of er zal weer sprake zijn van een krappe arbeidsmarkt voor technisch opgeleiden. Dit te meer omdat de komende jaren de uitstroom van medewerkers die met pensioen gaan, zal toenemen. De te verwachten toekomstige krapte op de arbeidsmarkt vereist dat bedrijven hun wervingskracht vergroten door een beleid dat zich richt op:

- Het bieden van een aantrekkelijk loopbaanperspectief aan nieuwe medewerkers.

- Het verder ontwikkelen van innovatieve manieren van samenwerking met het onderwijsveld.

- Het verbeteren van het imago van de metalektrosector.

- Het zelf opleiden van nieuwe medewerkers.

\section{Verspreiding van good practices en HR-tools}

Kleinere en middelgrote bedrijven moeten de effectiviteit van het arbeidsmarkt- en personeelsontwikkelingsbeleid vergroten door samenwerking en kennisdeling op regionaal niveau en het verspreiden van good practices en bruikbare HR-tools. De Stichting A+O Metalektro zou de ontwikkeling en verspreiding van deze HR-tools kunnen stimuleren. Met behulp van deze concrete HR-tools kunnen veel bedrijven in de Metalektro de effectiviteit van hun arbeidsmarkt- en personeelsontwikkelingsbeleid vergroten. 